\title{
WestVirginiaUniversity
}

THE RESEARCH REPOSITORY @ WVU

Graduate Theses, Dissertations, and Problem Reports

2014

\section{An Analysis of Marcel Breuer's Clarksburg-Harrison Public Library}

Szilvia Kadas

West Virginia University

Follow this and additional works at: https://researchrepository.wvu.edu/etd

\section{Recommended Citation}

Kadas, Szilvia, "An Analysis of Marcel Breuer's Clarksburg-Harrison Public Library" (2014). Graduate Theses, Dissertations, and Problem Reports. 842.

https://researchrepository.wvu.edu/etd/842

This Thesis is protected by copyright and/or related rights. It has been brought to you by the The Research Repository @ WVU with permission from the rights-holder(s). You are free to use this Thesis in any way that is permitted by the copyright and related rights legislation that applies to your use. For other uses you must obtain permission from the rights-holder(s) directly, unless additional rights are indicated by a Creative Commons license in the record and/ or on the work itself. This Thesis has been accepted for inclusion in WVU Graduate Theses, Dissertations, and Problem Reports collection by an authorized administrator of The Research Repository @ WVU. For more information, please contact researchrepository@mail.wvu.edu. 


\title{
An Analysis of Marcel Breuer's Clarksburg-Harrison Public Library
}

\author{
Szilvia Kadas \\ Thesis submitted to the \\ College of Creative Arts \\ at West Virginia University \\ in partial fulfillment of the requirements \\ for the degree of \\ Master of Arts \\ in \\ Art History \\ Examining Committee: \\ Kristina Olson, M.A., Chair \\ School of Art and Design \\ Rhonda Reymond, Ph.D., \\ School of Art and Design \\ Ron Dulaney Jr, M.Arch. \\ Division of Design \& Merchandising
}

Morgantown, West Virginia

2014 


\begin{abstract}
An Analysis of Marcel Breuer's Clarksburg-Harrison Public Library Szilvia Kadas
\end{abstract}

When Marcel Breuer accepted the commission to design the ClarksburgHarrison Public Library, West Virginia in 1973, he saw the opportunity to create a public space for the citizens of Clarksburg, where individuals could become one community and would feel at home. The library building was intended to fulfill the hope of the city board to bring social and cultural welfare to the citizens of Clarksburg.

My hypothesis is that Marcel Breuer created a unique and intimate public library in West Virginia by integrating his characteristically domestic design elements in a public library. This thesis will demonstrate the domestic nature of the Clarksburg-Harrison Public Library, by exploring the stylistic elements of Breuer's private family houses and by examining Breuer's design approaches, methodology and principles.

In the current scholarship on Breuer's work there has been no published attempt to analyze and to classify the Clarksburg-Harrison Public Library building. Therefore, my research is based on primary sources from the Syracuse University Library, Digital Archive, New York, the Archive of American Art, Smithsonian Institution, Washington, D.C. and the Clarksburg-Harrison Public Library, West Virginia. With this thesis my goal is to contribute to the scholarship on Marcel Breuer and to place this previously unanalyzed building in the context of Breuer's body of work. 


\section{ACKNOWLEDGMENTS}

First, I would like to thank my committee chair Professor Kristina Olson, and my committee members Dr. Rhonda Reymond, and Professor Ron Dulaney, for all their valuable advice and guidance they have provided during my research.

I would like to thank the help that Teresa M. Harris has provided me from the Marcel Breuer Digital Archive Syracuse University Libraries, and David Houchin from the Clarksburg-Harrison Public Library and the great on-line service of the Archives of American Art, Smithsonian Institution.

I am grateful to the Rajam family, who awarded me the Margaret Tavenner Rajam Art History Endowment, Graduate Student Travel Funds in 2013, which allowed me to visit the Clarksburg-Harrison Public Library, West Virginia, and the Whitney Museum of American Art, New York.

I also would like to express my gratefulness to my supportive family, who has always been there for me. 


\section{TABLE OF CONTENTS}

$\begin{array}{lll}\text { ABSTRACT } & \text { ii }\end{array}$

ACKNOWLEDGEMENTS iii

TABLE OF CONTENT

LIST OF IMAGES V v

INTRODUCTION

CHAPTER ONE

Biographical Background and Design Philosophy 10

\section{CHAPTER TWO}

Formal Analysis of the Clarksburg-Harrison Public Library 21

Main Entrance $\quad 32$

Windows-Light

$\begin{array}{ll}\text { Stairs } & 38\end{array}$

$\begin{array}{lr}\text { Furniture } & 40\end{array}$

Inner space of the library 43

Gardens $\quad 43$

$\begin{array}{ll}\text { Materials } & 47\end{array}$

CHAPTER THREE

Breuer's Large Scale Works 49

Case Study 1: The Whitney Museum of American Art, New York, NY 52

Case Study 2: Cleveland Museum of Art, Cleveland, OH 63

CHAPTER FOUR

Breuer's Medium-Scale Works: Breuer's Domestic Architecture 70

Case Study 3: Breuer House- New Canaan I, New Canaan, CT, 1947-48 76

Case Study 4: Wolfson (Trailer) House Pleasant Valley, NY, 1949-50 85

$\begin{array}{lr}\text { CONCLUSION } & 88\end{array}$

$\begin{array}{lr}\text { BIBLIOGRAPHY } & 90\end{array}$ 


\section{LIST OF IMAGES}

\section{Image}

Figure 1

Façade of the Clarksburg-Harrison Public Library, 1975

Clarksburg, WV

Photograph Source: taken by the author, 2013.

Figure 2

Clarksburg-Harrison Public Library, 1975

Street view

Clarksburg, WV

Photograph Source: google maps, 2013.

Figure 3

Clarksburg-Harrison Public Library, 1975

Elevation plan

Clarksburg, WV

Photograph Source: Clarksburg Harrison Public Library, West Virginia Collection.

Figure 4

Clarksburg-Harrison Public Library, 1975

Section Drawing

Clarksburg, WV

Photograph Source: Clarksburg Harrison Public Library, West Virginia Collection.

Figure 5

Clarksburg-Harrison Public Library, 1975

Southwest façade

Clarksburg, WV

Photograph Source: taken by the author, 2013.

Figure 6

Clarksburg-Harrison Public Library, 1975

Site Plan ground floor plan

Clarksburg, WV

Photograph Source: Clarksburg Harrison Public Library, West Virginia Collection.

Figure 7

Clarksburg-Harrison Public Library, 1975

Site Plan upper floor plan

Clarksburg, WV

Photograph Source: Clarksburg Harrison Public Library, West Virginia Collection. 
Figure 8

Clarksburg-Harrison Public Library, 1975

Main Lobby, first floor

Clarksburg, WV

Photo source: https://www.facebook.com/ClarksburgHarrisonPublicLibrary/photos_stream

Figure 9

Clarksburg-Harrison Public Library, 1975

First floor adult reading room

Clarksburg, WV

Photograph Source: taken by the author, 2013.

Figure 10

Clarksburg-Harrison Public Library, 1975

First floor children reading room

Clarksburg, WV

Photograph Source: taken by the author, 2013.

Figure 11

Clarksburg-Harrison Public Library, 1975

Second floor reading room

Clarksburg, WV

Photograph Source: taken by the author, 2013.

Figure 12

Clarksburg-Harrison Public Library, 1975

Front façade, explains the weight of the wall and window surfaces

Clarksburg, WV

Photograph Source: taken by the author, 2013.

Figure 13a

Clarksburg-Harrison Public Library, 1975

Satellite map

Clarksburg, WV

Photograph Source: google maps, 2013.

Figure $13 b$

Clarksburg-Harrison Public Library, 1975

Site Plan

Clarksburg, WV

Photograph Source: Clarksburg Harrison Public Library, West Virginia Collection. 
Figure 14

Clarksburg-Harrison Public Library, 1975

Parking lot entry vestibule and/or 'air lock'

Clarksburg, WV

Photograph Source: taken by the author, 2013.

Figure 15

Clarksburg-Harrison Public Library, 1975

Library rear facade with rear main entrance and the geometric negative shape

Clarksburg, WV

Photograph Source: taken by the author, 2013.

Figure 16

Clarksburg-Harrison Public Library, 1975

First and second floor help desk

Clarksburg, WV

Photograph Source: taken by the author, 2013.

Figure 17

Clarksburg-Harrison Public Library, 1975

First and second floor fluorescent light orientation

Clarksburg, WV

Photograph Source: taken by the author, 2013.

Figure 18

Clarksburg-Harrison Public Library, 1975

Second floor, reflection of the old library in the tilted windows

Clarksburg, WV

Photograph Source: taken by the author, 2013.

Figure 19

Waldomore, the old library, east to the Breuer building

Clarksburg, WV

Photograph Source: taken by the author, 2013.

Figure 20

Clarksburg-Harrison Public Library, 1975

The library staircase

Clarksburg, WV

Photograph Source: taken by the author, 2013.

Figure 21

Clarksburg-Harrison Public Library, 1975

Tubular steel cantilever "Cesca" chairs with bent-wood frame

Clarksburg, WV

Photograph Source: taken by the author, 2013. 
Figure 22

Tubular steel cantilever "Cesca" chairs with bent-wood frame

The original "Cesca" chairs, 1928.

Photograph Source: Archive of American Art

Figure 23

Breuer House- New Canaan I, 1947-48

48 interior with "Cesca" tubular chairs

New Canaan, CT

Photograph Source: Archive of American Art

Figure 24

Clarksburg-Harrison Public Library, 1975

Southwest garden for the adult reading room

Clarksburg, WV

Photograph Source: taken by the author, 2013.

Figure 25

Clarksburg-Harrison Public Library, 1975

Southeast garden for the children reading room

Clarksburg, WV

Photograph Source: taken by the author, 2013.

Figure 26

Clarksburg-Harrison Public Library, 1975

Southeast garden wall from the outside shows opening

Clarksburg, WV

Photograph Source: taken by the author, 2013.

Figure 27

Clarksburg-Harrison Public Library, 1975

Staircase, wall opening, allow the light come through

Clarksburg, WV

Photograph Source: taken by the author, 2013.

Figure 28

Department of Housing and Urban Development (HUD), 1968

Washington D.C.

Photograph Source: taken by the author, 2013.

Figure 29

Department of Health and Human Services Headquarters, 1977

Washington D.C.

Photograph Source: Marcel Breuer, Architectura, Camillio Gubitosi, 143. 
Figure 30

University of Massachusetts, Murray Lincoln Campus Center and Garage, 1967-70

Amherst, MA

Photograph Source: Hyman, Marcel Breuer, Architect book, 202.

Figure 31

The Whitney Museum of Modern Art, 1963

Frontal Façade

New York, NY

Photograph Source: Ezra Stoller: Whitney Museum of American Art

Figure 32

Clarksburg-Harrison Public Library, 1975

Frontal Façade

Clarksburg, WV

Photograph Source: Hyman, Marcel Breuer, Architect book, 188.

Figure 33

The Whitney Museum of Modern Art, 1963

Side view

New York, NY

Photograph Source: Wikipedia

Figure 34

Clarksburg-Harrison Public Library, 1975

Side view

Clarksburg, WV

Photograph Source: taken by the author, 2013.

Figure 35

Atlanta Central Public Library, 1980

Side view

Atlanta, GA

Photograph Source: Process Architecture, the Legacy of Marcel Breuer, 70.

Figure 36

Grosse Pointe Public Library, 1951-52

Side view

Grosse Pointe, MI

Photograph Source: Hyman, Marcel Breuer, Architect book, 186. 
Figure 37

The Whitney Museum of Modern Art, 1963

Tilted window

New York, NY

Photograph Source: segment of Ezra Stoller: Whitney Museum of American Art

Figure 38

Clarksburg-Harrison Public Library, 1975

Tilted window

Clarksburg, WV

Photograph Source: taken by the author, 2013.

Figure 39

Murray Lincoln Campus Center University of Massachusetts, 1969

Window

Amherst, MA

Photograph Source: Process Architecture, the Legacy of Marcel Breuer

Figure 40

New Campus High School, 1978

Window

Amherst, MA

Photograph Source: Process Architecture, the Legacy of Marcel Breuer

Figure 41

The Whitney Museum of Modern Art, 1963

Whitney Museum section drawing

New York, NY

Photograph Source: Ezra Stoller, Whitney Museum of American Art

Figure 42

Atlanta Central Public Library, 1980

Atlanta Central Library section drawing

Atlanta, GA

Photograph Source: Process Architecture, the Legacy of Marcel Breuer, 71.

Figure 43

Clarksburg-Harrison Public Library, 1975

Section Drawing

Clarksburg, WV

Photograph Source: Clarksburg Harrison Public Library, West Virginia Collection. 
Figure 44

The Whitney Museum of Modern Art, 1963

The sculpture garden and the entrance bridge from inside

New York, NY

Photograph Source: Ezra Stoller, Whitney Museum of American Art

Figure 45

Clarksburg -Harrison Public Library, 1975

Front main entrance

Clarksburg, WV

66

Photograph Source: taken by the author, 2013.

Figure 46a

The Cleveland Museum of Art Education Wing Expansion, 1968

Marcel Breuer and Hamilton P. Smith,

Cleveland, $\mathrm{OH}$

Photograph Source: Archives of American Art

Figure $46 b$

The Cleveland Museum of Art Education Wing Expansion, Canopy, 1968

Marcel Breuer and Hamilton P. Smith,

Cleveland, $\mathrm{OH}$

Photograph Source: Archives of American Art

Figure 47

The Whitney Museum of Modern Art, 1963

Canopy

New York, NY

Photograph Source: Ezra Stoller: Whitney Museum of American Art

Figure 48

Saint John's University Library, 1964-66

Canopy

Collegeville, MI

68

Photograph Source: from book Buildings and Projects, pg.39

Figure 49

New York University, University Heights Campus, 1959-70

Canopy

Bronx, New York

Photograph Source: from book Buildings and Projects, pg.64 
Figure 50

UNESCO Headquarters, 1955-58

Canopy

Paris, France

Photograph Source: Hyman, Marcel Breuer, Architect book, 237.

Figure 51

The Cleveland Museum of Art Education Wing Expansion, 1968

Lobby

Marcel Breuer and Hamilton P. Smith,

Cleveland, $\mathrm{OH}$

Photograph Source: taken by the author, 2013

Figure 52

The Whitney Museum of Modern Art, 1963

Lobby

New York, NY

69

Photograph Source: Ezra Stoller: Whitney Museum of American Art

Figure 53

Clarksburg-Harrison Public Library, 1975

Cantilevers

Clarksburg, WV

Photograph Source: taken by the author, 2013

Figure 54

Wolfson (Trailer) House, 1950

Pleasant Valley, NY

Photograph Source: Archive of American Art

Figure 55

Snower House, 1953-54

Kansas City, MI

Photograph Source: Hyman, Marcel Breuer, Architect book, 367.

Figure 56

Breuer House- New Canaan I, 1947-48

New Canaan, CT

Photograph Source: Archive of American Art

Figure 57

Breuer House- New Canaan I, 1947-48

New Canaan, CT

Photograph Source: Archive of American Art 
Figure 58

Breuer House- New Canaan I, 1947-48

Long House Plan

New Canaan, CT

Photograph Source: Archive of American Art

Figure 59

Breuer House- New Canaan I, 1947-48

Cantilevers

New Canaan, CT

Photograph Source: Archive of American Art

Figure 60

Clarksburg-Harrison Public Library, 1975

Cantilevers

Clarksburg, WV

Photograph Source: taken by the author, 2013.

Figure 61

Breuer House- New Canaan I, 1947-48

Separating the private areas from the public areas

New Canaan, CT

Photograph Source: Hyman, Marcel Breuer, Architect book.

Figure 62

Clarksburg -Harrison Public Library, 1975

Separating the private areas from the public areas, main level

Clarksburg, WV

Photograph Source: Clarksburg Harrison Public Library, West Virginia Collection.

Figure 63

Clarksburg -Harrison Public Library, 1975

Separating the private areas from the public areas, upper level

Clarksburg, WV

Photograph Source: Clarksburg Harrison Public Library, West Virginia Collection.

Figure 64

Breuer House- New Canaan II, 1951

Separating the private areas from the public areas

New Canaan, CT

Photograph Source: Hyman, Marcel Breuer, Architect book.

Figure 65

Wolfson (Trailer) House, 1950

Pleasant Valley, NY

Photograph Source: Archive of American Art 
Figure 66

Wolfson (Trailer) House, 1950

Top-heavy look

Pleasant Valley, NY

Photograph Source: Archive of American Art

Figure 67

Clarksburg-Harrison Public Library, 1975

Top-heavy look

Clarksburg, WV

Photograph Source: taken by the author, 2013

Figure 68

Wolfson (Trailer) House, 1950

Floor plan: main upper level

Pleasant Valley, NY

Photograph Source: Hyman, Marcel Breuer, Architect book.

Figure 69

Wolfson (Trailer) House, 1950

Floor plan: lower level

Pleasant Valley, NY

Photograph Source: Hyman, Marcel Breuer, Architect book. 


\section{INTRODUCTION}

Marcel Breuer (1902-1981) is widely considered to be one of the most influential modern architects of the twentieth century. Up until the 1950s Breuer's recognition was limited to his residential architecture in the United States and his early career as a furniture designer in Europe. Breuer was hired to design larger scale "monumental" buildings only from the 1950s. Breuer's architecture became monumental and robust, as he adopted a new material, the exposed concrete. The massive concrete walls gave his buildings a new visual articulation that led Breuer and his firm to a major success late in Breuer's career.

The Clarksburg-Harrison Public Library, West Virginia was built in 1973-1975, and can be examined within the context of Breuer's last period in his six decade-long professional career. The period between the mid-1950s to Breuer's retirement in 1976 was one of the most successful periods of his entire career, a time when the majority of his commissions were large scale buildings.

Breuer completed his most important commissions in this last period. Among his most famous works are the UNESCO headquarters in Paris, France (1953-58), the St. John's Abbey Church in Collegeville, Minnesota (1953-61), the new headquarters for the Department of Housing and Urban Development (HUD) in Washington D.C. (1965-68), the Whitney Museum of American Art, New York, New York (1964-66), the Church and Rectory of St. Francis de Sales, Muskegon, Michigan (1964-66), the Begrisch Hall, New York University, New York (1967-70), the IBM Office, Research and Manufacturing Facility, Boca Raton, Florida (1970, 1972 and 1978) and several other university and college buildings, research centers, factories, museums, libraries, churches and many residential houses and apartment complexes. 
Time Magazine, in its July 2, 1956 edition highlighted Breuer's contribution to modern architecture by naming him one of the "form givers" of the twentieth century along with thirteen other architects including Frank Lloyd Wright, Le Corbusier, Walter Gropius, Ludwig Mies van der Rohe, Richard Neutra, Philip Johnson, Gordon Bunshaft, Wallace K. Harrison, Minoru Yamasaki, I.M. Pei, Paul Rudolph, Buckminster Fuller and Eduardo Catalano. ${ }^{1}$

Marcel Breuer was an influential teacher, designer and architect. "You were the most influential teacher in America, building a 'bridge' to a new generation of today's outstanding architects such as Johnson, Rudolph, Pei, Barnes, Johansen." ${ }^{2}$ - said the French ambassador in his speech honoring Breuer in 1978 for his achievements, at the Grand Médaille d'Or ceremony.

Breuer designed more than 250 structures during his architectural career, from which 150 structures $^{3}$ were built in ten countries around the world, including the United States, Canada, Australia, England, France, Germany, the Netherlands, Belgium, Switzerland, and Argentina. In the United States Breuer has numerous structures built in more than 21 different states. Breuer had an office in New York from 1946 and in addition to that he opened a European office in 1964 in Paris. He was an internationally recognized and celebrated architect and designer. ${ }^{4}$

Breuer was awarded several honors in his lifetime; including the AIA gold medal, which he received in 1968. In addition, in the same year, Breuer was awarded the Thomas Jefferson Foundation Medal from the University of Virginia and an honorary doctorate from Harvard University in 1970. Breuer received the prestigious Grand Médaille d'Or from the Academy of

\footnotetext{
1 “The 20(th) Century Form Givers," New York Time, July 2, 1956.

${ }^{2}$ Smithsonian Online Archive, Marcel Breuer Collection, Speeches by Others: Typescript of speech honoring Breuer by the ambassador of France, 1978, Archive of American Art, Box 7, Reel 5719, Frames 130-133. http://www.aaa.si.edu/collections/container/viewer/Typescript-of-speech-honoring-Breuer-by-the-ambassador-ofFrance--179472

${ }^{3}$ This number does not include his industrial and furniture designs, or his interiors.

${ }^{4}$ Isabelle Hyman, Marcel Breuer, Architect, The Career and The Buildings (New York: Harry N. Abrahams, INC., publisher 2001), 13.
} 
Architecture, France in 1978. ${ }^{5}$ The French ambassador said at the ceremony, awarding Breuer the Grand Médaille d'Or honor, "You were never afraid of chaos because what people saw as chaos was often for you the mark of life." 6

Breuer was interested in "historic achievement," not passing "success", ${ }^{7}$ he kept careful documentation of all his work, and published several essays and books about his architectural views and philosophy throughout his career. Among Breuer's books are: Sun and Shadow: The philosophy of an architect, edited by Peter Blake and published in 1956, Buildings and Projects, 1921-1961, published in 1962, Marcel Breuer: new buildings and projects, published in 1970, Marcel Breuer - an exhibition organized by the Metropolitan Museum of Art, published in 1972, Marcel Breuer - architettura, 1921-1980, published in 1981, and Marcel Breuer - design and architecture: Vitra Design Museum, published in 2003.

In his lifetime, Breuer donated numerous drawings, papers and letters to the Syracuse University. A few years after his death, in 1987, his Associates, Robert F. Gatje and Tician Papachristou donated a large number of Breuer's materials to the Syracuse University. In the same year Breuer's widow, Constance L. Breuer, donated the remaining materials to the Archives of American Art, Smithsonian Institution, Washington D.C. ${ }^{8}$ Today these archives serve as an excellent primary digital source available to the public online. Besides these main Breuer collections there is a large amount of material kept at Harvard University, Houghton

\footnotetext{
${ }_{6}^{5}$ AAA, Marcel Breuer papers, 1920-1986, Bibliographic Information.

${ }^{6}$ Smithsonian Online Archive, Marcel Breuer Collection, Speeches by Others: Typescript of speech honoring Breuer by the ambassador of France, 1978, Archive of American Art, Box 7, Reel 5719, Frames 130-133. http://www.aaa.si.edu/collections/container/viewer/Typescript-of-speech-honoring-Breuer-by-the-ambassador-ofFrance--179472

${ }^{7}$ Blake, Peter, Marcel Breuer: Sun and Shadow, the Philosophy of an Architect (New York: Dood, Mead \&Company, 1956), 32.

${ }^{8}$ Hyman, Marcel Breuer, Architect, The Career and The Buildings (New York: Harry N. Abrahams, INC., publisher 2001), 7 .
} 
Library, MA, and the Bauhaus-Archiv, in Berlin as well. ${ }^{9}$ There have been many books published about Breuer that helped my research greatly - the comprehensive book by Isabelle Hyman: Marcel Breuer, Architect: the Career and the Buildings, Joachim Driller's, Marcel Breuer - die Wohnhäuser, Breuer Houses 1923-1973, Peter Blake's, Marcel Breuer, Architect and Designer, Christopher Wilk's, Marcel Breuer, Furniture and Interiors, Giulio Carlo Argan's, Marcel Breuer - disegno industriale e architettura, Gyula Ernyey's: Breuer Marcell Marcel Breuer Elvek és Eredmények Principles and Results, David Masello's: Architecture Without Rules - the Houses of Marcel Breuer and Herbert Beckhard, Robert F. Gatje's, Marcel Breuer - A Memoir, and William D. Earls', The Harvard Five.

Beside Isabelle Hyman's one-page description of the Clarksburg-Harrison Public Library in Marcel Breuer, Architect, the Career and the Buildings, almost nothing has been written about the library building. Therefore, one of my goals with this thesis is to bring attention to this littleknown building. As a result of the lack of published materials about the library, this study of the Clarksburg- Harrison Public Library, WV is mainly based on primary resources, such as the Marcel Breuer Digital Archive, Syracuse University Library, the Archive of American Art, Smithsonian Institution online database, and the Clarksburg-Harrison Public Library, WV. Secondary sources included the profound research of Isabell Hyman, Peter Blake and Joachim Driller all of which were essential to this study.

The Clarksburg-Harrison Public Library was not the only library Breuer designed during his career. Breuer's first public library design was the Grosse Pointe Public Library in Grosse Pointe, Michigan (1951-52)(See figure 36). Right around the time when Breuer already started working on the Clarksburg-Harrison Public Library's design, in Clarksburg, West Virginia (1973-1975) (See figure 1), he was commissioned to design the plans of the Atlanta Central

\footnotetext{
${ }^{9}$ Ibid., 7-9.
} 
Public Library, Atlanta, Georgia, which was only completed in 1980 (See figure 35). Beside these three public libraries, Breuer also designed libraries in universities and museums, such as the Hunter College Library, Classroom, and Administration Buildings, Bronx, New York (195760), Saint Hohn's University Library, Collegeville, Minnesota (1964-1966), and the Education Wing of the Cleveland Museum of Art, Cleveland, Ohio (1970) (See figure 46).

This study exam the Clarksburg-Harrison Public Library (1973-75) in the context of Marcel Breuer's work, by applying Breuer's design principles and architectural philosophies to the Clarksburg-Harison Public Library. Furthermore, this work intends to demonstrate the unique quality of the Clarksburg-Harrison Public Library and show that Breuer's residential house elements coexist here with those of a public building. The reason for this is that the Library Board commissioned Breuer with the intention of rehabilitating Clarksburg's community and creating a common "home" for the "children"" of Clarksburg. The City Manager of Clarksburg, Richard Barton, said to The Clarksburg Exponent in 1973, "We don't want our biggest export in the next ten years to be our children."11 The library's mission was to create a "new era" 12 and a "cohesive local community" ${ }^{13}$ for Clarksburg. The president of the board of the Clarksburg-Harrison Public Library, Mrs. George D. Curtin, stated: "Not only will the quality of life of Harrison County residents be enriched by Mr. Breuer's efforts but such efforts will signal a new era for Clarksburg. We hope it will signal the drawing together of all elements,

\footnotetext{
${ }^{10}$ Richard Barton quoted in "Marcel Breuer, World- Famous Architect to Design New Library Building Here. State Commission Gives \$400,000; County, City To Help; Funds Needed” The Clarksburg Exponent, Clarksburg, West Virginia, 11 January 1973, 1.

11 "200 Persons Desire Information On Proposed Development Plans; Parking Deck Is First on Agenda," The Clarksburg Exponent, Clarksburg, West Virginia, 11 January 1973.

${ }^{12}$ Mrs. George D. Curtin's, quoted in "Marcel Breuer, World- Famous Architect to Design New Library Building Here. State Commission Gives \$400,000; County, City To Help; Funds Needed" The Clarksburg Exponent, Clarksburg, West Virginia, 11 January 1973, 2.

${ }^{13}$ Ibid.
} 
especially ethnic and racial minorities into a cohesive local community." ${ }^{14}$ As a result, my hypothesis is that in an effort to satisfy the needs of the city of Clarksburg and the Library Board, Breuer designed an easily approachable library that resembles the appearance of his residential architecture in order to create a public home for the community of Clarksburg.

Bringing in an internationally well-known architect to Clarksburg, West Virginia was an attempt to rebuild and revitalize the city and thereby bring prosperity to the Appalachian area. In this time period, the city of Clarksburg had undergone a large drop in population, as the youth had left the city in hope of finding a brighter future elsewhere. ${ }^{15}$ The president of the board of the Clarksburg public library, Mrs.Curtin, said:

The Clarksburg Public Library Board is indeed proud to have the services of a man of Mr. Breuer's international architectural reputation. Throughout the time the Board has been considering architects, several factors were involved. Primary among these was our sense of obligation to bring cultural enrichment to the citizens of Clarksburg and Harrison County. Not only will a Marcel Breuer building be a first in the Appalachians area, it will be an enduring edifice for which Clarksburg will be famous. ${ }^{16}$

Despite the hard economic circumstances of Harrison County, the library board decided to invest in art and culture. The State Commission decided to fund the library with $\$ 400,000^{17}$, but the library board had a limited budget. ${ }^{18}$ According to the original project record book of

\footnotetext{
14 "Marcel Breuer, World- Famous Architect to Design New Library Building Here. State Commission Gives $\$ 400,000$; County, City To Help; Funds Needed" The Clarksburg Exponent, Clarksburg, West Virginia, 11 January $1973,2$.

${ }^{15}$ According the Census data, in 1970, the population of Clarksburg was 24.704 and the non-worker to the worker ratio was 1.52. The average median income of Families in Clarksburg was $\$ 7.910$. From the total families living in Clarksburg, $11.4 \%$ of the families were living under poverty level, and $9.1 \%$ earned more than $\$ 15.000 /$ household.Characteristics of The Population, West Virginia U.S Department of Commerce Publication, 1970, accessed April12, 2013, http://www2.census.gov/prod2/decennial/documents/00496492v1p50.zip

16 "Marcel Breuer, World- Famous Architect To Design New Library Building Here. State Commission Gives \$400,000; County, City To Help; Funds Needed" The Clarksburg Exponent, Clarksburg, West Virginia, 11 January $1973,1$.

${ }^{17}$ Idid.

${ }^{18}$ The president of CADA is Edward Carter.
} 
Breuer, the total cost of the building was $\$ 1,252,600 .{ }^{19}$ This modest budget for the ClarksburgHarrison Public Library was barely enough for a humble design. However, the library board could not have found a better architect to award the commission to in order to accommodate their needs, as Breuer created a cultural landmark for the city of Clarksburg and Harrison County. The Clarksburg Exponent published the following about the importance of the social type of building that Breuer was commissioned to build by the City Board:

Making the announcement that Breuer had been chosen by the Board, Mrs. Curtin referred to the writing of John Kenneth Galbraith, Harvard economist and former ambassador to India. Galbraith noted that public buildings in the early days of the American Republic were a source of local pride but over the years have acquired an institutional blandness showing little imagination. In 'Public Architecture and Public Works,' Galbraith stated. 'Public buildings have ceased to be a manifestation of public achievement, a source of public pride. We no longer build impressive courthouses or city halls. The federal Government continues to build but its new office buildings are square, functional antiseptic and anonymous... The return of a public structure is not merely the task that it facilitates. It is the whole pleasure that it provides the community." 20

Breuer believed that the building should reflect general values, and serve the needs of the commissioner and the public and not the personality or mood of the architect. Architecture for Breuer meant the expression of the social and functional needs of the building. Breuer stated in his speech at Cornell University in 1963:

As you know too well, there are many aspects one can and one should consider in talking about architecture. There is the practical aspect-necessary dimensions, costs, suitability of details and equipment, demands of circulation, perhaps of orientation, There is the social aspect - the attitude of the project, relation between effort and result, economies, relation to street, to community, to region. There is the structural aspect-inventiveness and engineering. There is an overall

\footnotetext{
${ }^{19}$ Smithsonian Online Archive, Marcel Breuer Collection, Project Books 3.2, 1953-1980 (Box 6, Reels 5717 Frame 1334-1337) http://www.aaa.si.edu/collections/container/viewer/Clarksburg-Public-Library--179375.

The building is constructed from brick and cement- block walls and dry-wall structure and acoustic ceiling.

20 "Marcel Breuer, World- Famous Architect to Design New Library Building Here. State Commission Gives \$400,000; County, City To Help; Funds Needed" The Clarksburg Exponent, Clarksburg, West Virginia, 11 January $1973,2$.
} 
conception-the inner relation of the different aspects, the aesthetics and philosophy of design- approach. ${ }^{21}$

With this library Breuer successfully addressed the needs of the board of the ClarksburgHarrison Public Library, to give the "children" of Clarksburg a community- building, where they would feel at home, and where they could feel they belong. Thus, the Public Library of Clarksburg was an investment with the hope of developing a healthier community of individuals that choose to stay in their hometown.

Breuer created in his design of the Clarksburg-Harrison Public Library a basic vocabulary to manifest the harmony between the individual and the community. Breuer brought to the city through his design, a sense of caring and nurturing for Clarksburg's citizens by blending into the design of the public library the elements of his residential architecture. As an architect and artist, Breuer sculpted his building with much playfulness to motivate the individual to grow into a community. Despite the fact that the library is functioning as a public space, in the following study my purpose is to guide the reader through the house elements and features of the building that manifest the nurturing aspects for the community of Clarksburg.

In my research, my goal is to apply formal-analyses to the Clarksburg-Harrison Public Library and to compare and contrast the building with other works of Breuer. First, in Chapter One, I present necessary background information on Breuer's professional life path and architectural philosophy that will help me establish the framework for Breuer's theoretical background when analyzing the Clarksburg-Harrison Public Library in Chapter Two. In Chapter Three, I continue with the discussion of some of the similarities with Breuer's other large-scale

\footnotetext{
${ }^{21}$ Smithsonian Online Archive, Marcel Breuer Collection, Speeches and Lectures by Breuer: Typescript of speech: "Remarks of Marcel Breuer," Cornell University, 1963, Archive of American Art, Box 7, Reel 5718, Frames 11941200. http://www.aaa.si.edu/collections/container/viewer/Typescript-of-speech-Remarks-of-Marcel-Breuer-CornellUniversity--179445.
} 
buildings. In an effort to shed light on the complexity and the unique house-like quality of the Clarksburg-Harrison Public Library, this study also analyzes Breuer's residential architecture and compares the elements of the library with Breuer's other house elements in Chapter Four. The analyses will include the main exterior body of the building: façade of the library, entrance door, windows, courtyards/terrace, and the interior of the building, such as staircase, natural and artificial lighting, and the floor plan as well. In the scale of this study my purpose is to limit my research on merely formal analysis and this study does not intend to investigate technical aspects of Breuer's architecture.

My hypothesis is that the Clarksburg-Harrison Public Library of Breuer is a unique design with the dual effect of combining, on the same platform, the appearance of the residential architectural design with the functional space of the modern public library. With this architectural philosophy Breuer was able to create a public library filled with inner meaning of home and nurturing. By incorporating the domestic design elements into the library, Breuer intended to help the citizens of Clarksburg to create a bond and connect with their city.

The following study outlines Breuer's system of incorporating the elements of his house design in the Clarksburg-Harrison Public Library's architecture. By comparing and contrasting the Clarksburg-Harrison Public Library with selected houses and buildings of Breuer this thesis is an attempt to understand the uniqueness of the Clarksburg-Harrison Public Library. It is hoped that through this work the Clarksburg-Harrison Public Library will bring more attention to this little known public building and be reconsidered in the light of the new context of community building. 


\section{CHAPTER ONE}

\section{Biographical Background and Design Philosophy}

Marcel Breuer was born Breuer Lajós Marcell in 1902, in the Hungarian city of Pécs, in the Austro-Hungarian Empire. Even as a young man, he showed extraordinary talent in the visual arts, and after finishing high school, he received a scholarship to the Academy of Art in Vienna as a sculpture student. Breuer, however, was overwhelmed with the traditional structure of the Academy and after the first week of school he left and joined the most progressive school of his time, the Bauhaus, ${ }^{22}$ in Weimar, Germany, where he became a student of Walter Gropius. Right after Breuer finished his education at the Bauhaus, he traveled to Paris, where he worked in a small architectural practice in 1924. In Paris Breuer met Le Corbusier. Ise Gropius ${ }^{23}$ who wrote in her diary in 1925 that Breuer "told us that he had had an offer from Le Corbusier at one time to join his office, but that he was not entirely satisfied with Le Corbusier's design approach which he found too formalistic." ${ }^{24}$ Though Breuer may not have agreed with Le Corbusier's "machine for living" architectural concept, his acquaintance with Le Corbusier had an extraordinary effect on Breuer's design philosophy and formal language. All throughout Breuer's career one can find similar approaches to materials and details as the Swiss born master. Breuer's first built house, the Harnischmacher house (1932, Wiesbaden, Germany), for example, resembles greatly Le Courbusier's Villa Savoye, Poissy, France, 1931. Peter Blake in his book Marcel Breuer: Architect and Designer make several comparisons with Le Corbusier's design

\footnotetext{
${ }^{22}$ The Bauhaus one of the most influential art and design schools of the 20th century, opened in 1919, in Weimar, Germany, as an attampt to revitalize the German economy by combining industrial manufacturing and the arts.

${ }^{23}$ Ise Gropius (1897-1983), was the wife of Walter Gropius.

${ }^{24}$ IGD/E, July 12, 1925, 54-55, Isabelle Hyman, Marcel Breuer, Architect, the Career and the Buildings (New York: Harry N. Abrahams, INC., 2001), 53.
} 
approaches and calls the Harnischmacher House "Breuer's Poissy". ${ }^{25}$ Although Breuer's intentions were to become an architect, and he worked in 1924 in an architectural practice in France, in 1925 Breuer returned from France to Germany and accepted the position of master of the carpentry workshop at the School of Bauhaus, Dessau. Breuer was only 23 years old when he made his first breakthrough in design, and invented the continuously bent, tubular steel frames for chairs and tables, for which many still remember him. Finally, in 1928 Breuer left his teaching position at the Bauhaus and started building his own architectural business in Berlin, Germany. He designed mainly apartment houses and single-family residences, but not many of them were actually built. In 1931 Breuer closed his office in Berlin and used his time to travel and to explore different cultures and architectures. In 1932 he wrote to Ise Gropius from Madrid, “... Shall I spend another nine years designing buildings which will never be built?" ${ }^{26}$ It was much harder for Breuer to break into the architectural world than one would think, especially after the worldwide success of his tubular chairs and the fact that Breuer built his architectural knowledge from practical experience and training. ${ }^{27}$ Breuer became recognized as a furniture designer rather than an architect, in Europe. ${ }^{28}$ Breuer moved to London in 1935 to work with F. R. S. Yorke. Right before Breuer left Europe for the United States in 1937, he stated in an interview to a Hungarian newspaper:

My sudden idea to use the material of the bike's handlebar, guided me to the tubular furniture construction that had spread one minute to another across the world, however this absolutely did not mean that I am as an architect going to

\footnotetext{
${ }^{25}$ Peter Blake, Marcel Breuer: Sun and Shadow, the Philosophy of an Architect (New York: Dood, Mead \&Company, 1956), 40.

${ }^{26}$ Joachim Driller, Breuer Houses (London: Phaidon, 2000), 12.

${ }^{27}$ Breuer worked at the private practice of Gropius and several other architectural practices.

28 Although many architects at the time had only practical experience, such as Gropius and Mies van der Rohe, who were trained in the practice of Peter Behrens, in Germany.
} 
spend my whole life designing furniture. Try to forget me as the tube furniture designer and accept me as an architect. ${ }^{29}$

Driller in his book Breuer Houses talks about Breuer's acceptance into the German architects' society; the Bund Deutscher Architekten finally accepted him in March 1931, due to a recommendation by Gropius and because of Breuer's participation in the German section of the CIAM (Congrès Internationaux d'Architecture Moderne). It was not easy for Breuer to break into the field of architecture. Breuer mainly earned his living from renovating and refurbishing older apartments. Driller also observes that Breuer's first commission was completed only in 1932 (Harnischmacher House, Wiesbaden, Germany), and even later, Breuer's houses from 1932 to the mid-1950s were not as lavish as the villas of Le Corbusier or as Mies van der Rohe's house commissions. Cost-efficiency was very important to Breuer. Hyman concludes in her book Marcel Breuer the Architect:

Breuer was committed to architectural mass and to the concrete that gave it expression and he had an abiding faith in systems of standardization. This, together with his inveterate respect for a client's budget, led him to make design choices based less on aesthetics than on economy, on what Tician Papachristou remembers as his "European 1920 s fear of cost. ${ }^{30}$

The Bauhaus' main principles of function and structure were encoded in Breuer all through his career as a teacher and as a designer as well. The Bauhaus' aim was to give a clean, aesthetically pleasing and functional form to mass produced items through standardization, and Breuer always stayed committed to these principals. However, Breuer refused to be identified with a single formal language or architectural style. Breuer stated in his speech at the Walker

\footnotetext{
${ }^{29}$ Syracuse University Library, Marcel Breuer Digital Archive, image ID MAR-05014_001_003 and MAR05014_001_004, http://breuer.syr.edu/xtf/view?docId=mets/25057.mets.xml;query=;brand=breuer Translated from original Hungarian by the author.

${ }^{30}$ Isabelle Hyman, Marcel Breuer, Architect, the Career and the Buildings (New York: Harry N. Abrahams, INC., 2001), 151.
} 
Center in 1959, "Modern architecture is not a style, it is an attitude. The designer frees himself from precedent and starts fresh. He analyzes the functional and structural needs of the building, and considers the social implications of the assignment. The result is usually simple in lines, striking in effect." ${ }^{31}$ This freedom from strict architectural rules allowed Breuer to experiment and reinvent his aproach in every project. That may be the reason why Breuer's different functional buildings look so significanly different, as his designs were the outcome of the functional, structural, and social needs of the building. From this aspect it is not suprising that many structures with similar functions have similar visual outcome in Breuer's work. Breuer in his speech for panel discussion Individual Expression Versus Order, said in 1961: "While I do not agree with a modern style, in a general sense, I think that characteristic forms for each species of building are developing. Office buildings will probably develop to an architecture rather differenly from that of our apartment buildings or hospitals, or theaters, or laboratories." 32 Although all of the Bauhaus teachers ${ }^{33}$ had different approaches, they shared the goal of making the students work on standardization. Gropius stated in his book The New Architecture and the Bauhaus, "Just as the mechanization of industry has provided new tools for its realization. Our ambition was to rouse the creative artist from his other-world-liness and reintegrate him into the workday world of realities: and at the same time to broaden and humanize the rigid, almost exclusively material, mind of the business man." ${ }^{34}$

\footnotetext{
${ }^{31}$ Breuer, lecture at the Walker Center, Minneapolis, Minnesota, June 1959, Speeches and Writings, AAA.

${ }^{32}$ Smithsonian Online Archive, Marcel Breuer Collection, Speeches and Lectures by Breuer: Typescript of speech for panel discussion: "Individual Expression Versus Order: The Issue in Architecture Today," Architectural League of New York (also given in Toronto, 1974), 1961 (Box 7, Reel 5718, Frames 1070-1091), http://www.aaa.si.edu/collections/container/viewer/Typescript-of-article-On-Concrete-published-in-emph-renderitalic-Architecture-Formes-et-Fonction-emph-s--179468.

${ }^{33}$ Gropius gathered around himself a handful of well known non conventional, avant-garde artists to teach at the new school of design. Among the teachers were Paul Klee, Wassily Kandinsky, Lászlo Moholy-Nagy, Johannes Ittens and Lyonek Feininger.

${ }^{34}$ Walter Gropius, The New Architecture and the Bauhaus, (Boston: Charles T. Branford, 1955), 89-90.
} 
Breuer believed in the beauty of simplicity as well, and he refused to use any applied ornamentation in his design. As Breuer explained in his essay, "Where do we stand?" modern architecture is "striving after clarity, or, if you prefer it, sincerity." And then he continued to explain what he meant by clarity:

The principle of clarity, as we understand it, expresses itself in the technical and economical fields of architecture through emphasis on structural laws and practical functions; and in the aesthetic field by simplicity and renunciation of irrational forms. The New Architecture might be compared to a crystalline structure in process of formation. Its laws correspond to human laws and functions, which are other than those of nature or organic bodies. In its more immediate conception, New Architecture is the "container" of men's domiciles, the orbit of their lives. ${ }^{35}$

Breuer later explained why there is no need for ornamentation in modern life: "I think it is one all important change in our lives: we have learned to move faster- faster than anyone ever moved before. We no longer see little details, disconnected or detached from the overall picture. We see continuities." ${ }^{36}$ However, for Breuer, the individual expression was just as important as standardization.

Breuer moved to the United States in $1937,{ }^{37}$ right after Gropius was appointed to be the head of the Architecture Department at Harvard University, Cambridge, Massachusetts, and Gropius offered Breuer partnership and a position as a teacher at Harvard University. ${ }^{38}$ At

\footnotetext{
${ }^{35}$ Ernyey Gyula, Breuer Marcell Marcel Breuer, Érvek és Eredmények, Principles and Results (Pécs, Pro-Pannonia Kiadó, 2008), 58.

${ }^{36}$ Peter Blake, Marcel Breuer: Sun and Shadow, the Philosophy of an Architect (New York: Dood, Mead \&Company, 1956), 60.

${ }^{37}$ Despite the world wide success and acknowledgement of the Bauhaus, after 1933, for most of the Bauhaus teachers there were not many work opportunities left in Germany. Almost all of the teachers and most of the students had to leave the country and spread across the world.

${ }^{38}$ Breuer worked in London, Great Britain, before he followed Gropius to Boston, MA. Among many Mies van der Rohe also moved to the United States, and was offered a teaching position at the Illinois Institute of Technology (IIT) in Chicago, IL. Mies van der Rohe implemented a brand new generation of the box-shape skyscrapers, based on clear structure of glass and steel. The former Bauhausers had a major impact on the landscapes of American cities.
} 
Harvard, Breuer became "one of the most succesful teachers of architecture this century has ever seen- and , incidently, one of the most popular." ${ }^{39}$ Part of the success must have been due to the fact that "Gropius and Breuer believed that it was more important to train a student how to think than to tell him what to think" ${ }^{, 40}$ and also the fact that Gropius and Breuer brought a very new and modern perspective to the American architect students. "In the fall of 1937, when Walter Gropius and Marcel Breuer came to the United States and began teaching architecture at Harvard, most architectural schools in this country were still part of the eclectic Beaux Art system." ${ }^{41}$ Among Breuer's student were I.M. Pei, Philip Johnson, Paul Rudolph, John A. Johansen, Eliot F. Noyes, Edward L. Barnes, and many others who became the most creative and influential architects in the United States. Breuer also worked together with four of his students: John M. Johansen, Landis A. Gores, Philip A. Johnson and Eliot F. Noyes, and formed the Harvard Five Group, building single family houses for clients in New Canaan, Connecticut. ${ }^{42}$ Breuer worked in partnership with Gropius until 1941, when he became an independent architect working in Cambridge, Massachusetts. "The private houses which Breuer designed in partnership with Gropius helped to pave the path for his later success," -wrote Driller in his book Breuer Houses. ${ }^{43}$ Up until the 1950s, Breuer was known for his achievements as a professor, for his furniture designs and his single family houses. After the ultimate success of the UNESCO Building in Paris, France in 1955-58, Breuer finally was able to break with the stigma of being exclusively a "house architect," however he never stopped desiging them even when he had large-scale commissions, late in his career.

\footnotetext{
${ }^{39}$ Peter Blake, Marcel Breuer: Sun and Shadow, the Philosophy of an Architect (New York: Dood, Mead \&Company, 1956), 140.

${ }^{40}$ Ibid., 60.

${ }^{41}$ Ibid., 140.

${ }^{42}$ William D. Earls, The Harvard Five in New Canaan (New York: W.W. Norton \& Company, 2006).

${ }^{43}$ Joachim Driller, Breuer Houses (London: Phaidon, 2000), 15.
} 
Besides light and clarity Breuer was aiming to provide shelter and privacy in his designs. Breuer provided a common ground where the large transparent windows coexisted with the mass wall architecture. Perhaps that is why he was often called "the last modernist" 44 and "the youngest from the Bauhaus rebels. ${ }^{, 45}$ Breuer explained his views of architecture in an interview at Harvard University in the fall of 1966:

In the twenties or the thirties the architect wanted to create a completely bodiless space because space was the new invention. And this space was to be as little material as possible. There was a thin structure, a thin skin, transparent, only space; only how many steps you make from one enclosure to another, this is space.... architecture is something rather abstract, floating and immaterial. After we did some of these spaces, on account of some inner need which you call the development or change of the spirit of the time, mass appealed to us, gravity, solidity, a wall you can lean against and not just a glass wall, which limits your movements. And this change has pushed architecture into what we call a more sculptural concept of architecture. ${ }^{46}$

Although trained in the Bauhaus, Breuer was considered a late-modernist architect.

Breuer created a unique sculptural architecture by applying heavy mass walls and a monumental sculptural quality to his designs that was a step away from the architecture of the "fathers of the Modernism:" Walter Gropius, Mies van der Rohe and Le Corbusier. Breuer was much more monumental, sculptural and robust after the 50s both in his large scale and his residential architecture, than in his earlier period. Hyman in her book Marcel Breuer, Architect describes Breuer's expression, "For his powerfully flexed 'Brutalist' concrete structures, which coexisted with the floating, transparent slabs and glass-and metal curtain-wall boxes that dominated the architectural landscape in the 1960s, Breuer was regarded at the Graduate School of Design as

\footnotetext{
${ }^{44}$ Newsweek, 17 August, 1981, 70.

${ }^{45}$ Clipping, review of Marcel Breuer: Buildings and Projects, 1921-1961, edited by Cranston Jones, Times (London), nd.[ca. 1963]], AAA.

${ }^{46}$ Isabelle Hyman, Marcel Breuer, Architect, the Career and the Buildings (New York: Harry N. Abrahams, INC., 2001), 149 .
} 
'one of the leaders of the recent massive, sculptural trend in design'." 47 On his large-flexed concrete structures Breuer created a three dimensional façade. Breuer writes about the material in On Concrete in 1971: "The concrete research of the last decades gives us a new vocabulary for architecture - deep shadows, the three- dimensional rhythm of facades - erected with a minimum of hand labor, utilizing the technique of prefabrication." ${ }^{48}$ Breuer's large concrete structures were already a step away from the Bauhaus, setting the tone for Expressionism and Brutalism in architecture.

After thirteen years of being known as a successful house architect and as a popular teacher in the United States, in 1950 Breuer was finally commissioned to build a large scale building, a new dormitory for the Vassar College, and he was also chosen to design the UNESCO Headquarter building in Paris. ${ }^{49}$ Due to the growing success Breuer hired more architects to work for him. In 1956, Breuer recognized the need to reorganize his firm's structure and changed the name to "Marcel Breuer and Associates." Among the associates were Herbert Beckhard, Murray Emslie, Robert F. Gatje and Hamilton P.Smith. After ten years, the associates became full partners, with a small change as Emslie resigned and, in 1974, Tician Papachristou became a new associate partner. ${ }^{50}$

In the early 1950s Breuer finally accomplished what he was aiming for so many years, to build large-scale buildings and to be accepted as an architect designing in all scales and functions. Breuer saw his career as a systematic development from small details to larger scale

\footnotetext{
${ }^{47}$ Ibid., 150.

${ }^{48}$ Smithsonian Online Archive, Marcel Breuer Collection, Articles and Books by Breuer: Typescript of article: "On Concrete," published in Architecture Formes et Fonctions, 1971 (Box 7, Reel 5719, Frames 114-119) http://www.aaa.si.edu/collections/container/viewer/Typescript-of-article-On-Concrete-published-in-emph-renderitalic-Architecture-Formes-et-Fonction-emph-s--179468.

${ }^{49}$ Peter Blake, Marcel Breuer: Sun and Shadow, the Philosophy of an Architect (New York: Dood, Mead \&Company, 1956), 140.

${ }^{50}$ Isabelle Hyman, Marcel Breuer, Architect, the Career and the Buildings (New York: Harry N. Abrahams, INC., 2001), 137.
} 
works. He stated in an interview given to the Hungarian reporter István Kardos, in 1972 that his career development from small-scale furniture designs to medium-scale houses and later largescale building were part of his design plan:

To make chairs wasn't the most important thing for me, for back then, a decisive plan for my life already took shape. I actually planned to process from smaller to ever bigger units. Therefore, I first studied smaller pieces, namely chairs and other furniture. Then I continued with details of buildings, like windows, locks, later on doors, lighting and other small pieces.... According to my work program, I moved from furniture to private houses, I built a large number of private houses or villas, especially in the United States, approximately 70-75 houses. I always considered this a study, as a private house or else a smaller design allows for things which are not possible in larger buildings. These are experiments; with different window solutions, with different materials, flooring and lighting. ${ }^{51}$

This interview clearly demonstrates Breuer's deliberate distinction between furniture, house and large-scale building design; furthermore it also indicates that these classifications of small, medium and later large-scale designs were driven by functional considerations rather than stylistic choices. Breuer makes it clear in his interview that every time he mentions "house" he means "private residence." He explains in the same interview to Kardos, "When we are talking about 'houses' it is a private residential house. In the United States, the word 'house' cannot be applied to an apartment building or a theater that is not a 'house.' The word 'house' expresses that it is a private residence. ${ }^{52}$

Breuer created a philosophy of architecture, rather than a rigid and systematic style. This philosophy was based on the principle of contrast. He called it, "Sol y Sombra" or "Sun and

\footnotetext{
${ }^{51}$ Smithsonian Online Archive, Marcel Breuer Collection, Transcripts: Transcripts of interview of Breuer by television reporter István Kardos, 1972, (Box 6, Reels 5718 Frame 508-530), http://www.aaa.si.edu/collections/container/viewer/Transcript-of-interview-of-Breuer-by-television-reporterIstv\%C3\%A1n-Kardos--179410. Translated from Hungarian to English by the author.

${ }^{52}$ Smithsonian Online Archive, Marcel Breuer Collection, Transcripts: Transcripts of interview of Breuer by television reporter István Kardos, 1972, (Box 6, Reels 5718 Frame 508-530), http://www.aaa.si.edu/collections/container/viewer/Transcript-of-interview-of-Breuer-by-television-reporterIstv\%C3\%A1n-Kardos--179410.Translated from Hungarian to English by the author.
} 
Shadow." When looking at Breuer's stylistic characteristic as a whole, one soon realizes that the principle of contrast flows through his work, and unifies it. Breuer found beauty in contrast and tension. He believed that the only way to reach harmony in design was to create balance between the two opposite poles such as sun and shadow, negative and positive spaces, transparency and solidity, support and weight, and building and nature. "The easy method of meeting contrasting problems is the feeble compromise. The solution for black and white is gray- that is the easy way. To me this is not satisfying. Sun and shadow does not mean a cloudy sky. The need for black and the need for white still exist." ${ }^{53}$ The ability for opposite poles in one platform to coexist creates the unique timelessness and universal quality of Breuer's work. Breuer separates nature and architecture (as a man-made structure), into two opposite poles and creates a contrast. Breuer states in his writings about architecture on the landscape, "A building is a thing in itself. It has a right to be there, as it is, and together with nature. I see it not as an isolated composition, but a composition related to nature, a composition of contrast." ${ }^{54}$

"Sol y Sombra" may be the case at the Clarksburg-Harrison Public Library, as Breuer decided to let the two opposite poles live together on one platform in order to create a feeling of home: the domestic medium-scale design together with the large-scale building. Breuer addressed this in his remarks at the symposium "What is Happening to Modern Architecture?" at the Museum of Modern Art in 1948:

The perfection of construction and detail is there, together with and in contrast to simplicity, broadmindedness of form and use. The courage of conception is there, together with and in contrast to humble responsibility towards the client. The sensation of man-made space, geometry, and architecture is there, together with

\footnotetext{
${ }^{53}$ Peter Blake, Marcel Breuer: Sun and Shadow, the Philosophy of an Architect (New York: Dood, Mead \&Company, 1956), 32.

${ }^{54}$ Ibid., 38.
} 
and in contrast to organic forms of nature and of man. "Sol y Sombra," as the Spanish say; sun and shadow, not sun or shadow. ${ }^{55}$

"Sol y Sombra" as the philosophy of contrast, and standardization as the solution for the modern library will be recognizable as the general overall architectural philosophy of Marcel Breuer. In the next chapter I explain how Breuer articulates his philosophical ideas into physical manifestation.

\footnotetext{
${ }^{55}$ Marcel Breuer, Marcel Breuer: An Exhibition Organized by the Metropolitan Museum of Art (New York: The Metropolitan Museum of Art, 1972), 1.
} 


\section{CHAPTER TWO}

Formal Analysis of the Clarksburg-Harrison Public Library

In this chapter I examine the Clarksburg-Harrison Public Library closely and conduct a formal analysis of the building. After a general overview of the building it is necessary to carefully study the different elements of the Clarksburg-Harrison Public Library, as Breuer designed the entire interior and exterior of the library. Each individual element manifests the overall idea of creating a comfortable and accessible library, where the citizens of Clarksburg can feel at home and become one community.

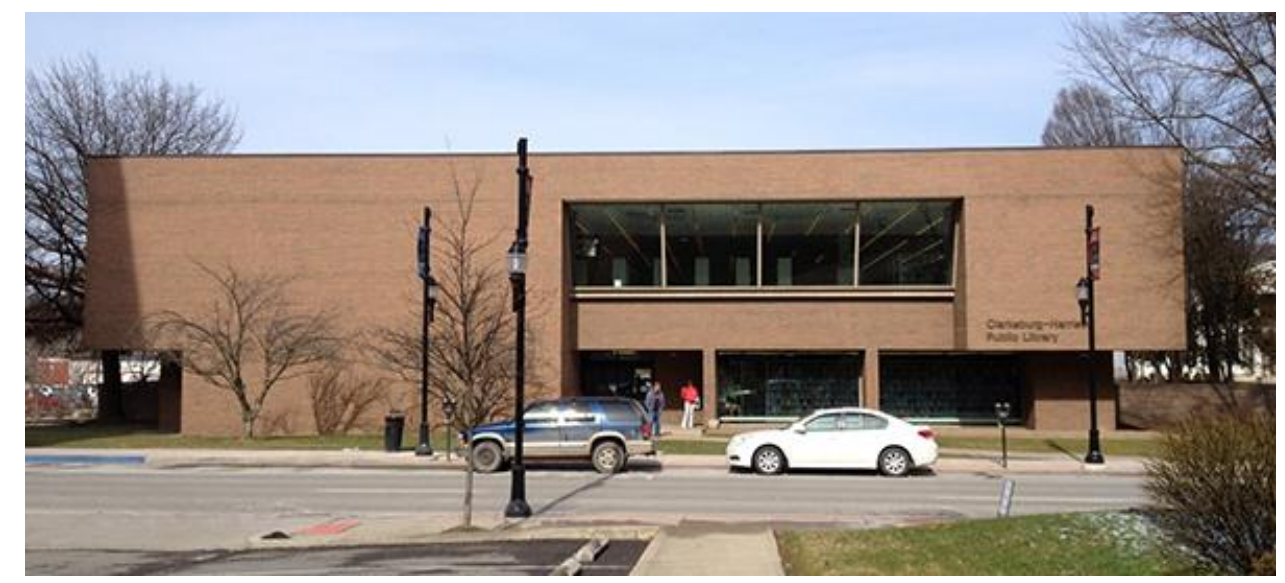

Figure 1: Clarksburg-Harrison Public Library front south-eastern entrance facade.

On January 11, 1973, the Clarksburg Exponent announced, - "Marcel Breuer, World Famous Architect, to Design New Library Building Here." 56 Marcel Breuer and associate architect Hamilton Smith, worked along with the contractor Mellon-Stuart Company, from Pittsburgh, Pennsylvania. Marcel Breuer was commissioned in 1973 to build a new library

\footnotetext{
${ }^{56}$ Front page headlines in The Clarksburg Exponent, Clarksburg, West Virginia, 11 January 1973, 1.
} 
building next to the old public library called Waldomore. ${ }^{57}$ The new building of ClarksburgHarrison Public Library (See figure 1) was completed in November 1975, and Waldomore now serves as the West Virginia Collection (See figure 19). The new library is located next to the old Waldomore building, at the center of the business district of Clarksburg, on West Pike Street. (See figure 2 and 13a and 13b). The Clarksburg-Harrison Public Library stands out from the rest of the structures on this site, with its modern characteristics. The library is set among colonial and revival style buildings, which indicate the long history of Clarksburg. As the rest of the buildings look to the past, Breuer's building represents the future, and communicates that the city of Clarksburg is open to innovations and further developments. Breuer and his associate choose brick as the material of the façade of the library. "Clarksburg is a brick-built town; the old library is preserved on the same site. Brick was chosen therefore as the exterior material for the new building," wrote the associate architect, Hamilton Smith on December 22, $1976 .{ }^{58}$ The twostoried, blocky building of the Clarksburg-Harrison Public Library has a humble design. It was constructed with basic construction techniques and from cost- efficient materials, as the library had a limited budget. According to Breuer's original project record book, the total cost of the construction was $\$ 1,252,600 .^{59}$ The representatives of the library board, Merle Moore, librarian at the Clarksburg library and Richard Davis, Board Director of Clarksburg wanted a three-story

\footnotetext{
${ }^{57}$ Waldomore was the only library building in Clarksburg for more than 40 years. However over the years as the collection grew they needed more space. They expanded many times the building of Waldomore, however, around 1970 the library board agreed on building a new addition to this building. Waldomore is an antebellum house that today is one of the city's historical landmarks. Waldomore now holds the West Virginia Collection and other meeting rooms. See source: Waldomore, David Houchin, Clarksburg-Harrison Library, accessed April12, 2013, http://clarksburglibrary.info/waldomore.html\#hours.

${ }^{58}$ Isabelle Hyman, Marcel Breuer, Architect, the Career and the Buildings (New York: Harry N. Abrahams, INC., 2001), 188.

${ }^{59}$ Smithsonian Online Archive, Marcel Breuer Collection, Project Books 3.2, 1953-1980 (Box 6, Reels 5717 Frame 1334-1337) http://www.aaa.si.edu/collections/container/viewer/Clarksburg-Public-Library--179375.

The building is constructed from brick and cement- block walls and dry-wall structure and acoustic ceiling.
} 
high building, but it would have been above their budget, therefore, Breuer and the library board agreed on a "reduced program" which resulted in only a two-story high building.

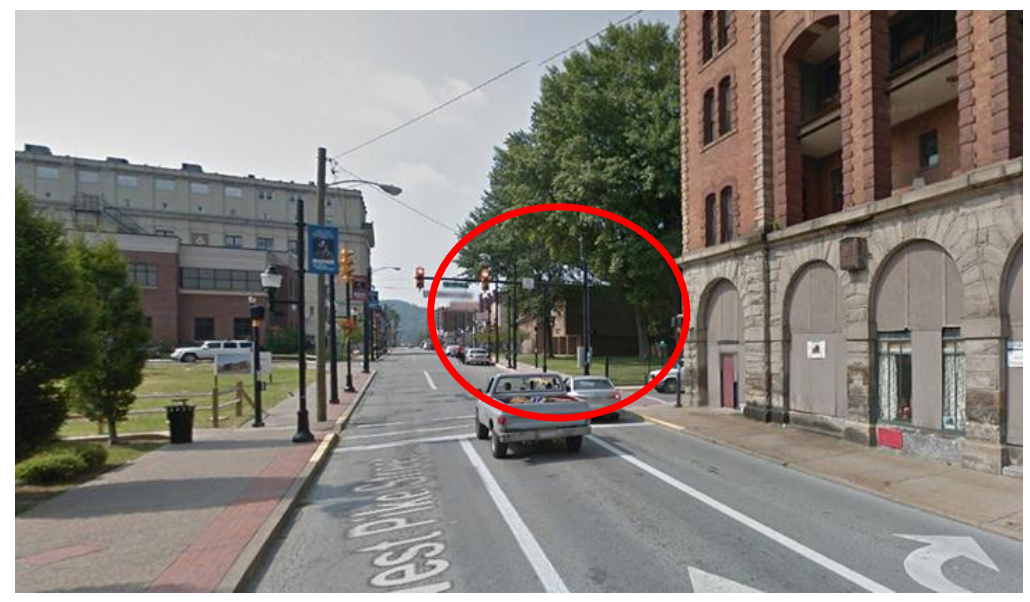

Figure 2: Street view of the Clarksburg-Harrison Public Library, Clarksburg, West Virginia.

The Clarksburg-Harrison Public Library ${ }^{60}$ is very reductive and functional. Many elements of the building can be linked with the concept of standardization and with social and communal sensitivity indicating that Breuer reached back to the Bauhaus principles. The flat roof, pilotis, lack of applied ornamentation, clear façade, orthogonal geometry, and open floor plan may resemble the International style architecture at first glance, but when one takes a better look, there are some features of the Clarksburg-Harrison Public Library that tell a different story. The pilotis and the window wall on the front main entrance façade indicate the modern transparent aspect of the building; however, Breuer balanced the transparent glass wall by placing brick walls around them that appear heavy and robust, in order to create the feeling of protection and shelter (See figure 12). This is an example of his philosophy of "Sol y Sombra," creating harmony of the different poles. The window wall lets the daylight in, and creates bright reading rooms; however, the heavy mass dominates the building, giving a sensation of security and

\footnotetext{
${ }^{60}$ The library's exterior did not have major renovations and restorations; however the interior of the building has been changed to a great extent.
} 
shelter. Breuer's library is well set in the ground giving a reassuring feeling that it is here to stay for eternity. Also Breuer cuts geometric shapes into the wall of the clear façade. These voids create a stage for the play of light on the surface of the wall. This creates moving shadows on the façade as the sun moves throughout the day and breaks the monotony and brings movement into the heavy mass. Breuer sculpted his building like a modern sculpture, by cutting out right-angled geometric forms from the square (See figure 3).

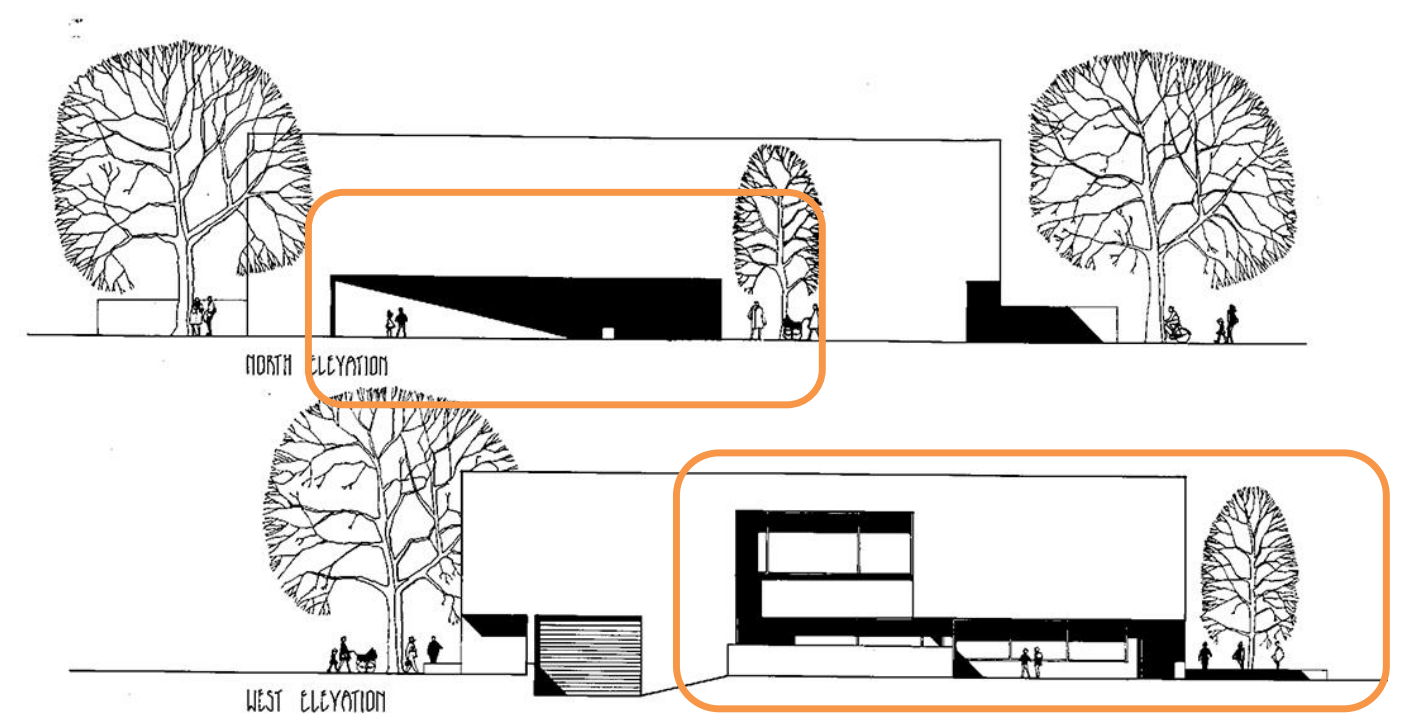

Figure 3: Clarksburg-Harrison Public Library, elevation plan. The plans clearly demonstrate the shadows that Breuer intentionally calculated into his design.

The other element that breaks the monotony of the block and creates dynamics is the building's strong asymmetrical balance. Breuer created asymmetry by designing the windows off-center on the façade. Breuer revealed his theories on architecture in his speech accepting the Gold Medal from the American Institute of Architects, in 1968, "Buildings should not be moody, but reflect a general, durable quality. Architecture should be more direct, more directly responsible, more directly social, more technic-bound, more independent; symmetrical or non- 
symmetrical." ${ }^{61}$ Marcel Breuer's symbolic and sculptural approach and the visually heavy thick walls connect with Breuer's large-scale building designs, created at the end of his career.

However, the façade of the library resembles Breuer's house architecture, creating a home-like and inviting look, which gives the building a warmer and more approachable appearance. Breuer, by designing the Clarksburg- Harrison Public Library, with these two approaches, created a public home for the community of Clarksburg, West Virginia. The homelike impression of the Clarksburg- Harrison Public Library and the link with Breuer's residential architecture is discussed in depth in Chapter Four, where I will explore not only the domestic influences of the public library, but also its significance to Breuer's overall architectural philosophy.

In order to emphasize volume and gravity, Breuer made the library building top-heavy; and he achieved this effect by increasing the height of the top floor. The first floor has the average height of a private residence (9'-0”); however, the second floor is (12”-0) (See figure 4).

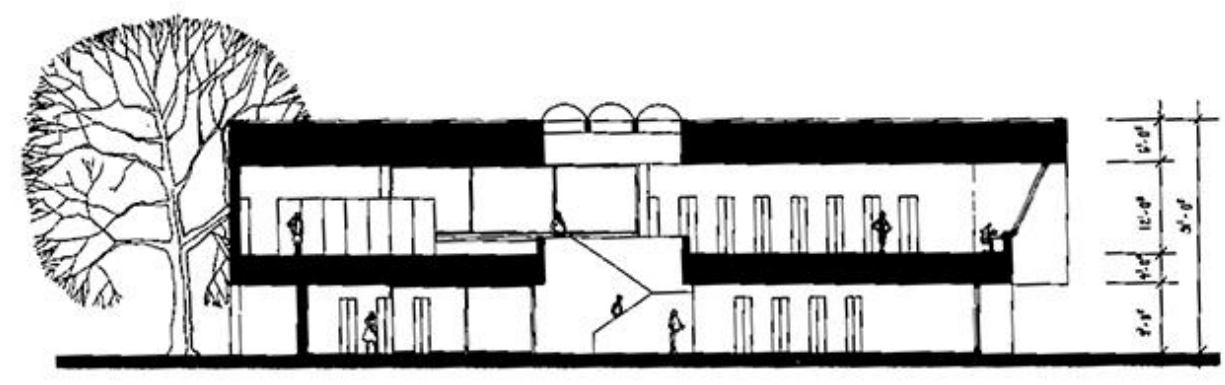

Jtcilat

Figure 4: Clarksburg-Harrison Public Library, Building Section Drawing. The drawing shows the different height of the floors and floor- roof assemblies.

\footnotetext{
${ }^{61}$ Smithsonian Online Archive, Marcel Breuer Collection, Speeches and Lectures by Breuer: Typescript of speech accepting Gold Medal from the American Institute of Architects, 1968 (Box 7, Reels 5718 Frame 1255-1260) http://www.aaa.si.edu/collections/container/viewer/Typescript-of-speech-accepting-Gold-Medal-from-theAmerican-Institute-of-Architects--179450.
} 
This difference in the height of the two levels gives the library a top-heavy and monumental look from the outside. This feature provides a feeling of compression and release when observed from the inside. We see this in other modernists' works as well - most notably in Le Corbusier's villas, e.g., Villa Stein and Villa Savoye. This abstracted form of the classical piano nobile ${ }^{62}$ further "monumentalizes" the building (See figure 5). Breuer used the piano nobile at the Whitney Museum's design where he created the massive appearance by adding more height on the upper levels of his building. Interestingly the impression of the monumental look of the piano nobile can also be found in Breuer's house designs. This aspect will be further analyzed in Chapters Three and Four.

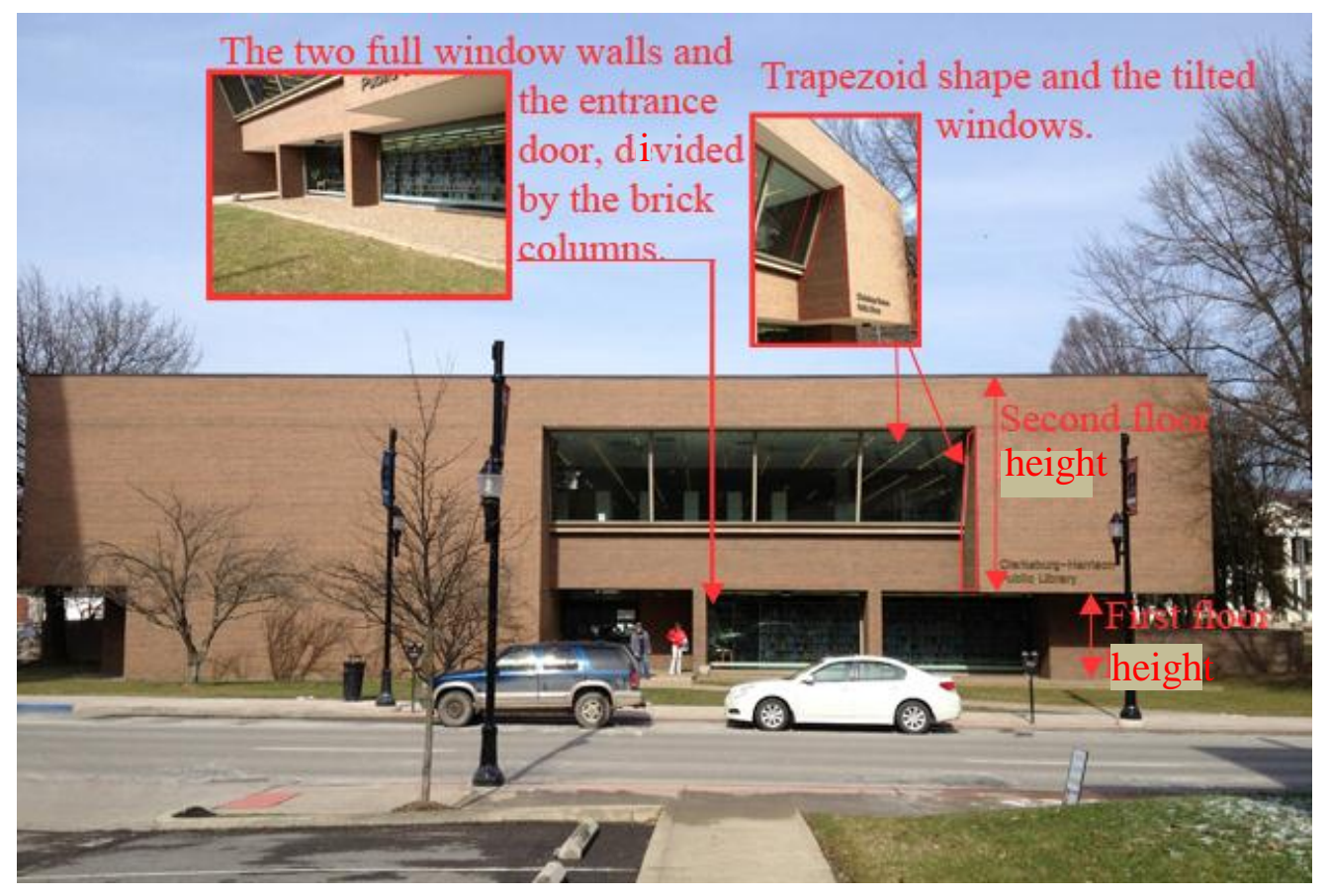

Figure 5: Southwest façade of the Clarksburg-Harrison Library, 1975, WV.

\footnotetext{
${ }^{62}$ Piano nobile was the principle of the classical renaissance architecture, placing the main/noble floor above the ground floor. This main floor had usually higher ceiling than the ground floor.
} 
As one walks up the stairs to the second floor, there is a sense of openness, due to the large and bright open floor plan the visitor encounters (See figure 7). The fact that the lower level has the height of a private residence, and it is segmented to smaller areas ${ }^{63}$ (See figure 6) gives the visitor the feeling of entering a private residential house rather than a public building. The second floor in contrast to the first floor ${ }^{64}$ has a different environment; it opens up, it has an open floor plan and high ceiling. This aspect connects to Breuer's intention of creating a gathering place for the community of Clarksburg. Providing the sensation of comfort combined with the intellectual/high spirited atmosphere was a way to create a place where the community could bind through culture.

\footnotetext{
${ }^{63}$ The first floor is divided into three smaller "reading rooms," and an office space, while the second floor is one open space (except for a few offices and restrooms on the left side of the second floor). The second floor is slightly larger than the first floor due to the overhanging cantilevered space.

${ }^{64}$ The different height of the floors will be further discussed later in this chapter.
} 


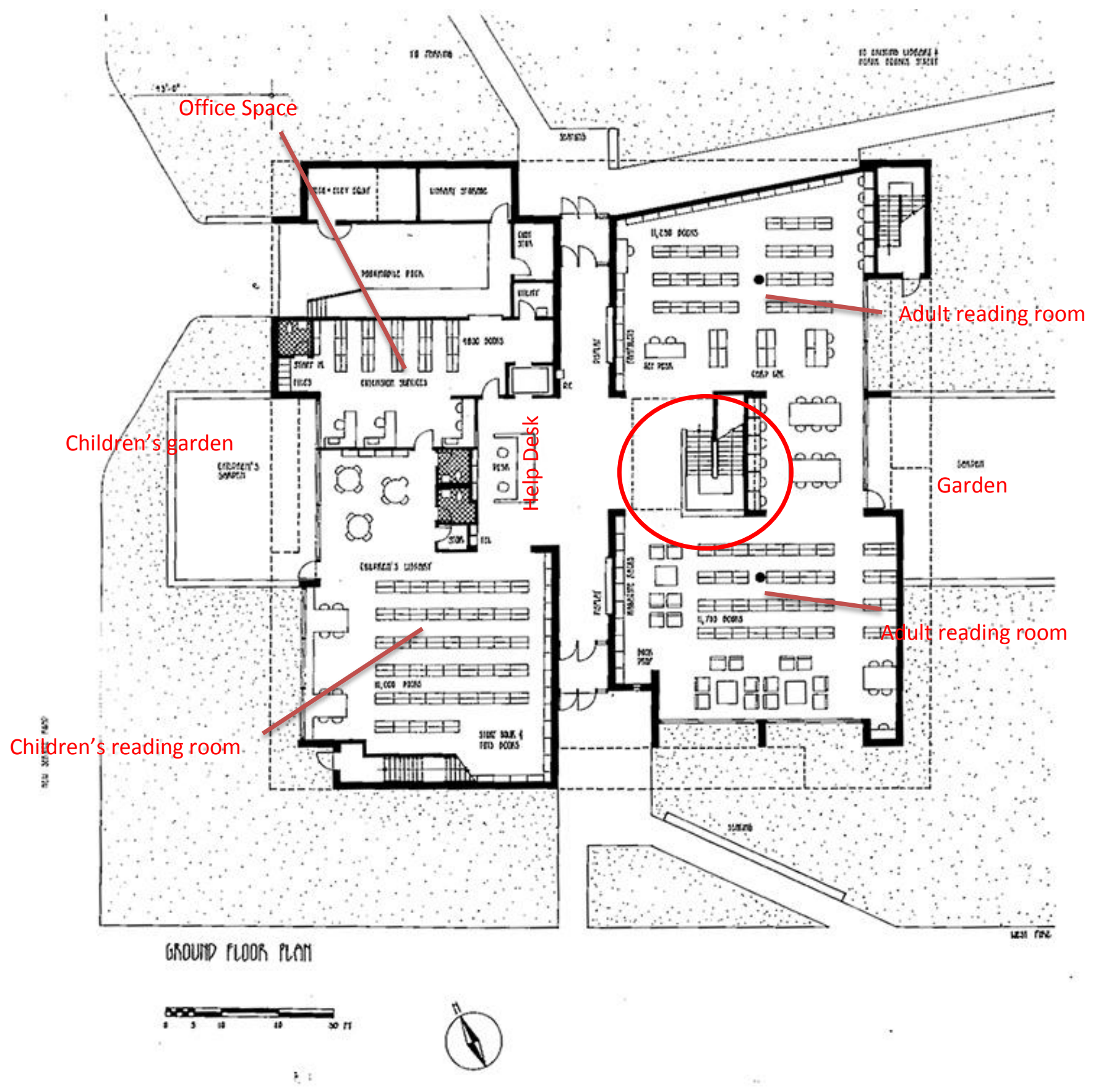

Figure 6: Clarksburg-Harrison Public Library, site plan ground floor, in red circle the central staircase. 

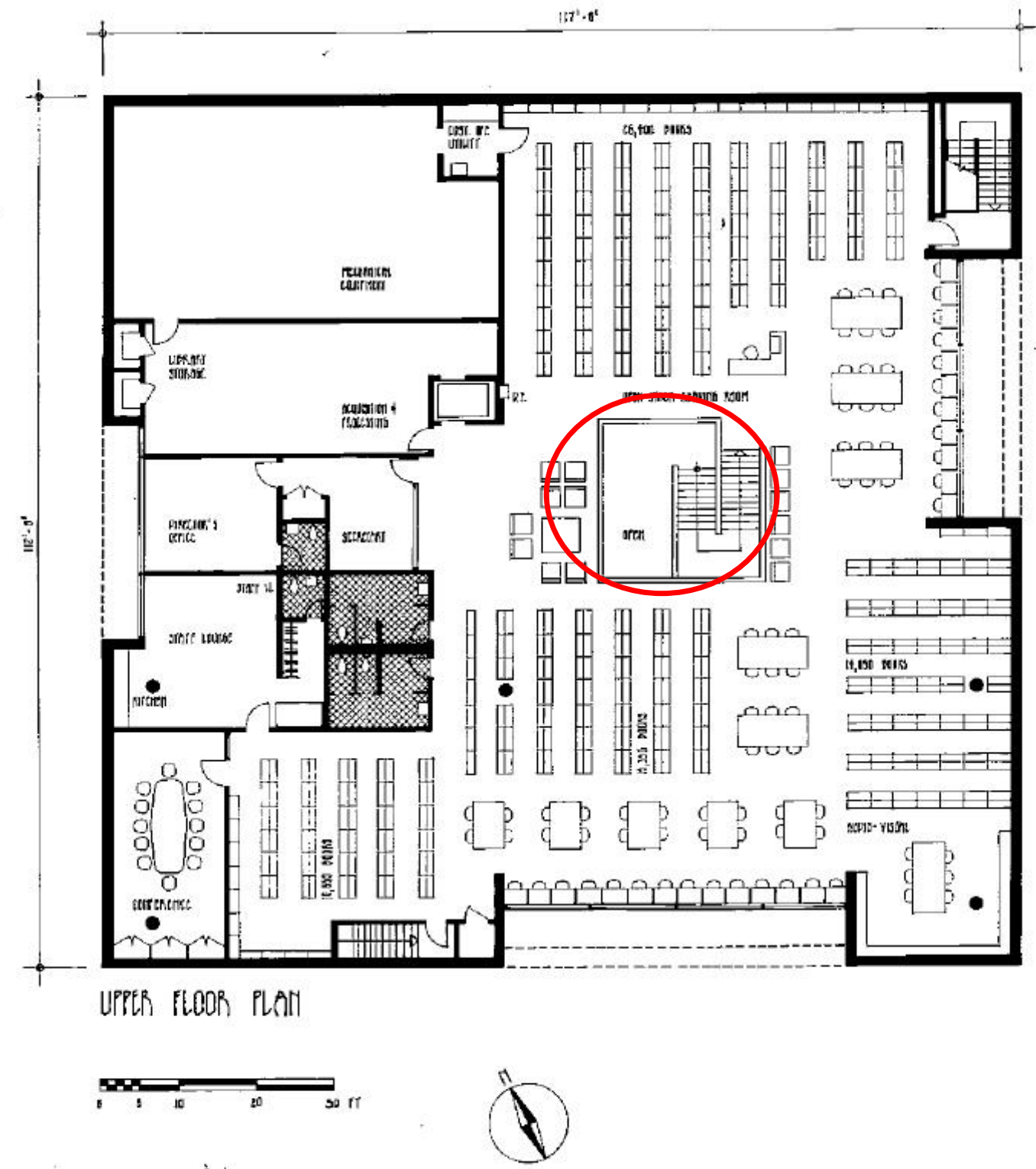

Figure 7: Clarksburg-Harrison Public Library, site plan second floor, in red circle the central staircase. This depicts the large open floor plan of the second floor. 

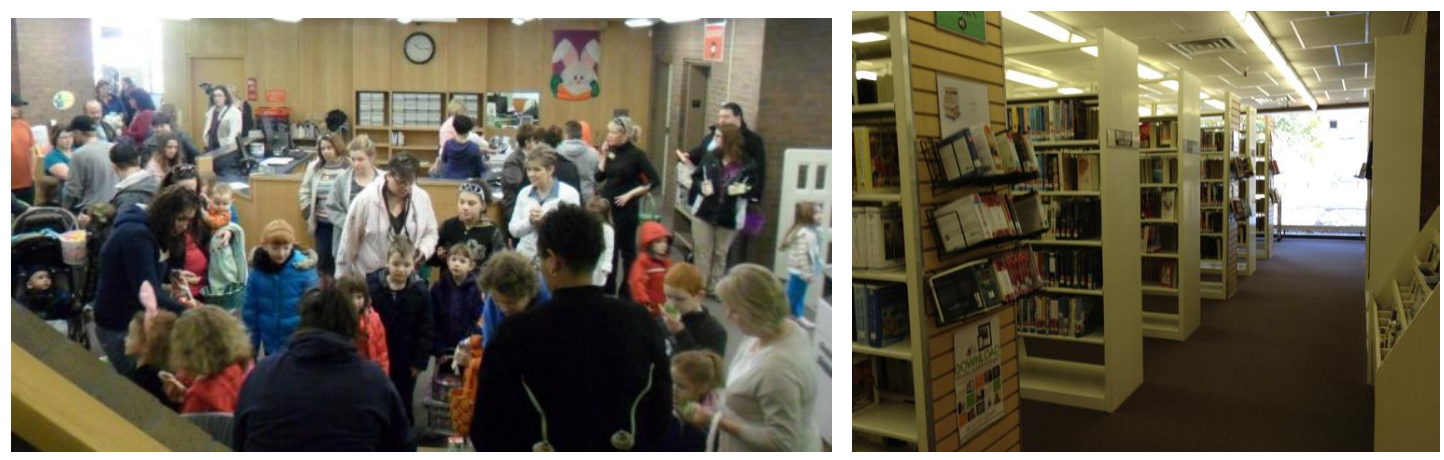

Figure 8: Main lobby today, looking from the stairs to the reception desk. The two entrances are at left and right. Figure 9: Library's first floor, adult reading room
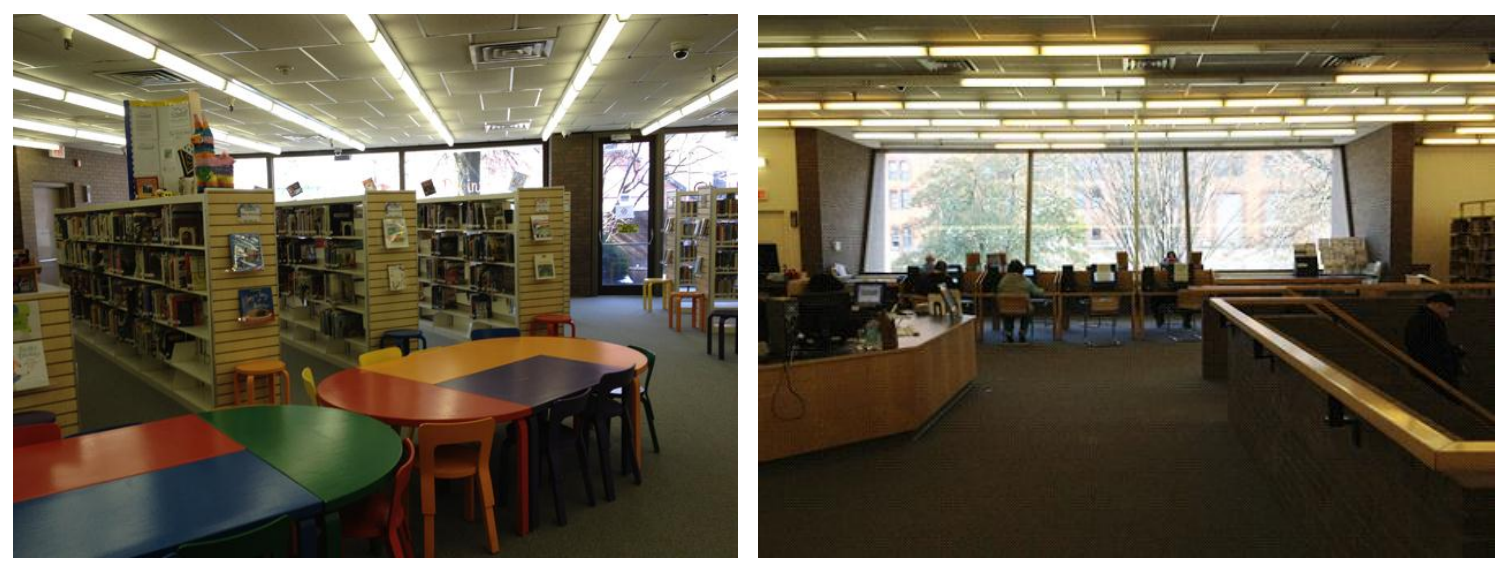

Figure 10: Library's first floor, children's reading room. Figure 11: Library's second floor, tilted windows from the inside and the help desk right in front of the staircase.

The second floor serves as a space for gathering and interacting, and less as a space for being alone and uninterrupted. The public can enter as individuals on the first floor and gather as a community on the second. "Sol y Sombra" manifests itself in Breuer's design, letting the two opposite poles coexist in the same platform.

If one looks at the visual weight of the façade of the library, it is easy to see that the amount of solid surfaces is greater than the amount of transparent surfaces; however, Breuer manages to create the sensation of a very bright, glass wall library from the inside, due to the openness and continuity of the interior space (See figure 12). 


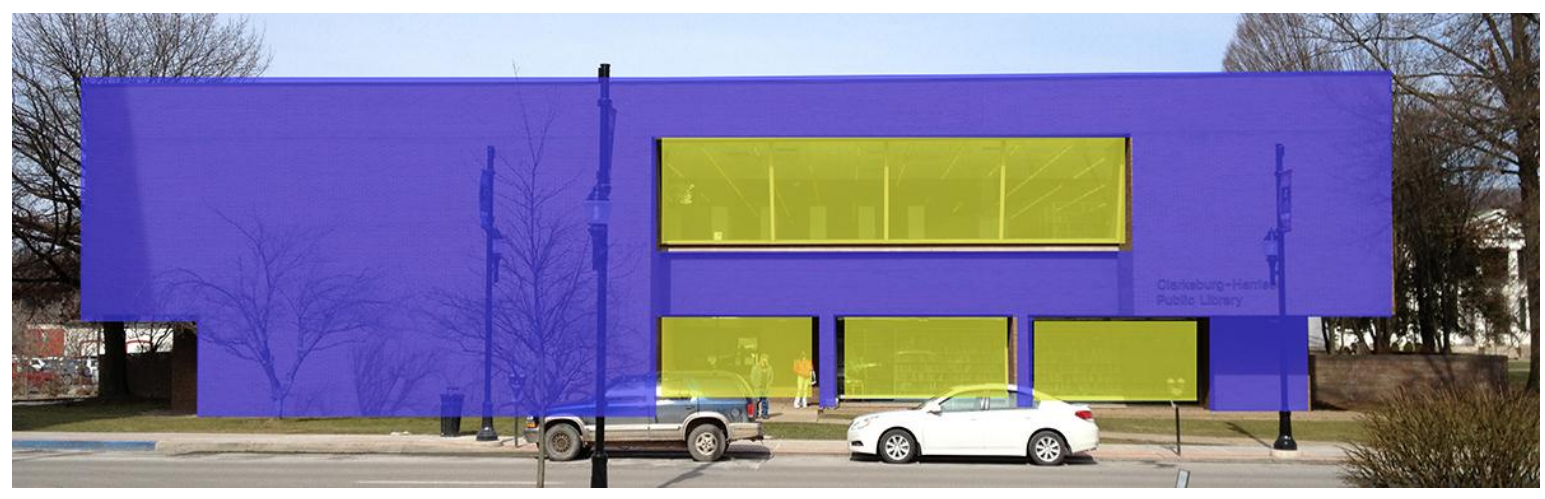

Figure 12: Superimposed analytical diagram: southwest façade of the Clarksburg-Harrison Public Library, highlighting the weight of the wall and window surfaces.

Early in his career, Breuer had the chance to experiment with different architectural elements such as windows, doors, lightning, and staircases. As Breuer's "work program" was to begin with the small and move to the bigger elements, it is necessary to look at the elements such as windows, lighting, and staircases of the building individually as well. Breuer's library was a "Gesamtkunstwerk" or "total work of art", Breuer designs both the exterior and interior of the building. ${ }^{65}$ This is why it is important to have a closer look at each architectural element of the library. An analysis of the library's windows, stairs, furniture, inner space, gardens and materials will follow.

\footnotetext{
${ }^{65}$ The Bauhaus adapted the term "Gesamtkunstwerk" or "total work of art" to create a visual and functional unity between all art forms, as conceptually the school was based on the theories of the Arts and Crafts movement that was introduced to the Bauhaus by the creator of the Deutscher Werkbund, the German architect Hermann Muthesius.
} 


\section{Main entrances}

The library has two main entrances, ${ }^{66}$ one is the southwest entrance that allows the public to enter from the street front (West Pike Street) and other is the northeast entrance from the library's rear side that allows the public to enter from the parking lot (See figure 13a and 13).

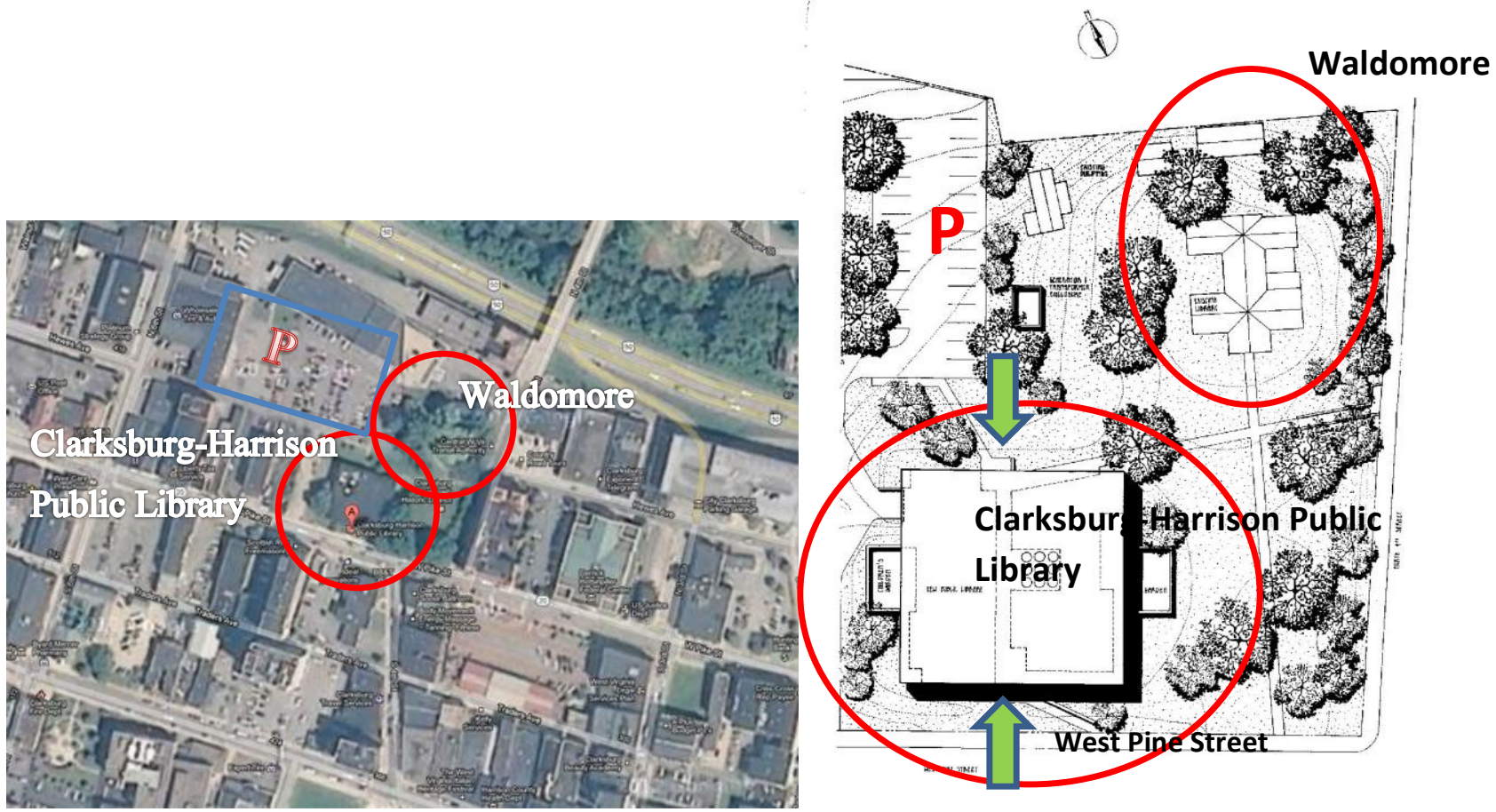

Figure 13a: Satellite map of the Clarksburg-Harrison Public Library, Clarksburg, West Virginia. Figure 13b: Clarksburg-Harrison Public Library, from above, shows the location of the Clarksburg-Harrison Public Library on the arboretum, the Waldomore building, West Pine Street and the Parking lot.

The two entrances do not create a monumental feeling; there is no canopy, columns or stairs that would emphasize the entrance. The entrance is on the ground level, there is no need to climb stairs; therefore, it is very accessible for children, seniors and people with disabilities. There is practically no difficulty for anyone to enter the library. Both entrances are identical from the inside; on each side there are two doors. The two doors are placed at a distance of 230 inches from each other, which creates an entry vestibule or air lock, right before entering the library. In

\footnotetext{
${ }^{66}$ The entrance doors have been replaced.
} 
addition to creating visual symmetry, this is also a great way to control the cold or hot air entering the library space. The doors are mechanical today. ${ }^{67}$ Both airlocks are 108 inches high and 108 inches wide, which makes the shape of the entrance cubic. By making both entrances identical, it gives the visitor the impression that the two kinds of arrival, whether on foot or by car, are just as equally accepted and encouraged (See figure 14).

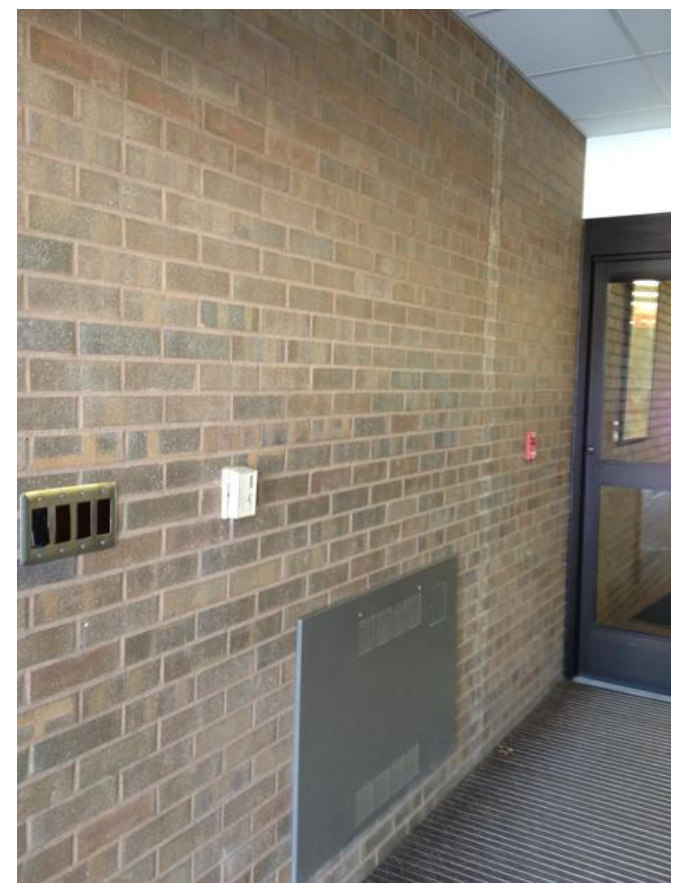

Figure 14: Parking lot entry vestibule and 'air lock'

Although the two entrance doors are completely identical, the front and the rear façades of the building are different from each other. While the main entrance has two full glass walls which make the building look lighter, the back side entrance, by contrast, is very closed in and protective. Although the rear façade does not have any windows, it has a trapezoid shape cut into it, leading the visitors into the entrance of the library. Breuer breaks the monotony of the rectangular shape of the building by inserting negative shapes, voids, which give the impression

\footnotetext{
${ }^{67}$ The doors were not replaced authentically.
} 
as if these shapes were cut out from the building. These geometric "cut outs" function as a unifying element over the building (See figure 15).

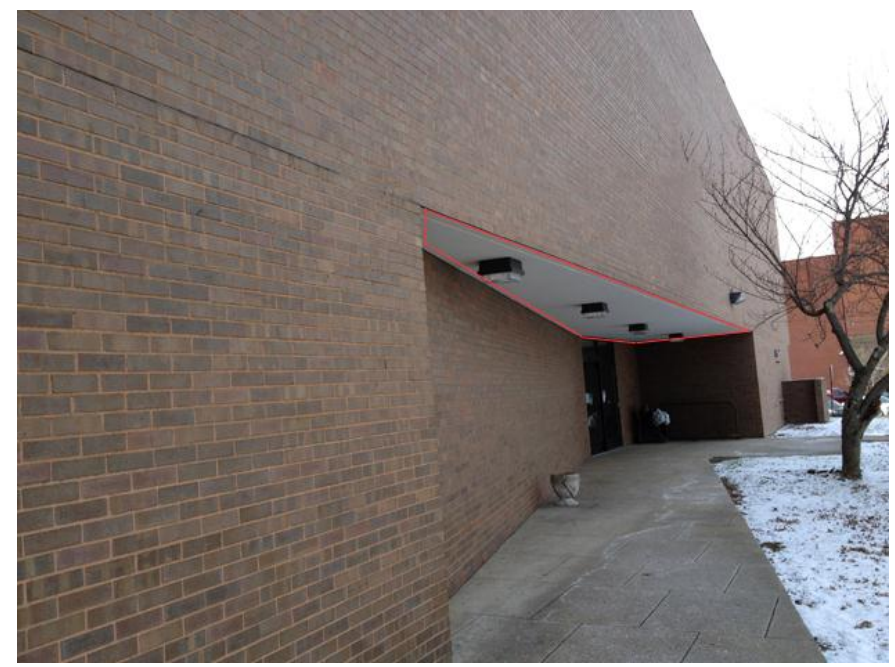

Figure 15: Library rear façade with rear entrance and the geometric negative shape, cut-out.

Entering the building, the visitor finds him/herself in a small lobby, in the center of the library. Here the visitor can find the main librarian help desk, where books can be checked out and returned, the staircase and the elevator. The librarian desk is no longer the original, it has been replaced; however, the area where it was situated originally is the same as today. The library help desks on both first and second floor are quite large, accessible from all angles. It is placed on the first floor right between the two main entrances and on the second floor right before the stairs (See figure 16). This once again reinforces the sensation of accessibility. One can approach the help-desk ${ }^{68}$ from all directions, from all paths. The staff is there to help no matter where the person is coming from. The fact that the help desk is large and central also signifies importance. Help is available and visible. Thus, asking for help is encouraged, and

\footnotetext{
${ }^{68}$ The original furniture of the help desk is not in use anymore, it has been replaced, but the location is the same as Breuer intended in his original drawings.
} 
welcomed. The library is very functional and the navigation is very clear and easy inside the library.
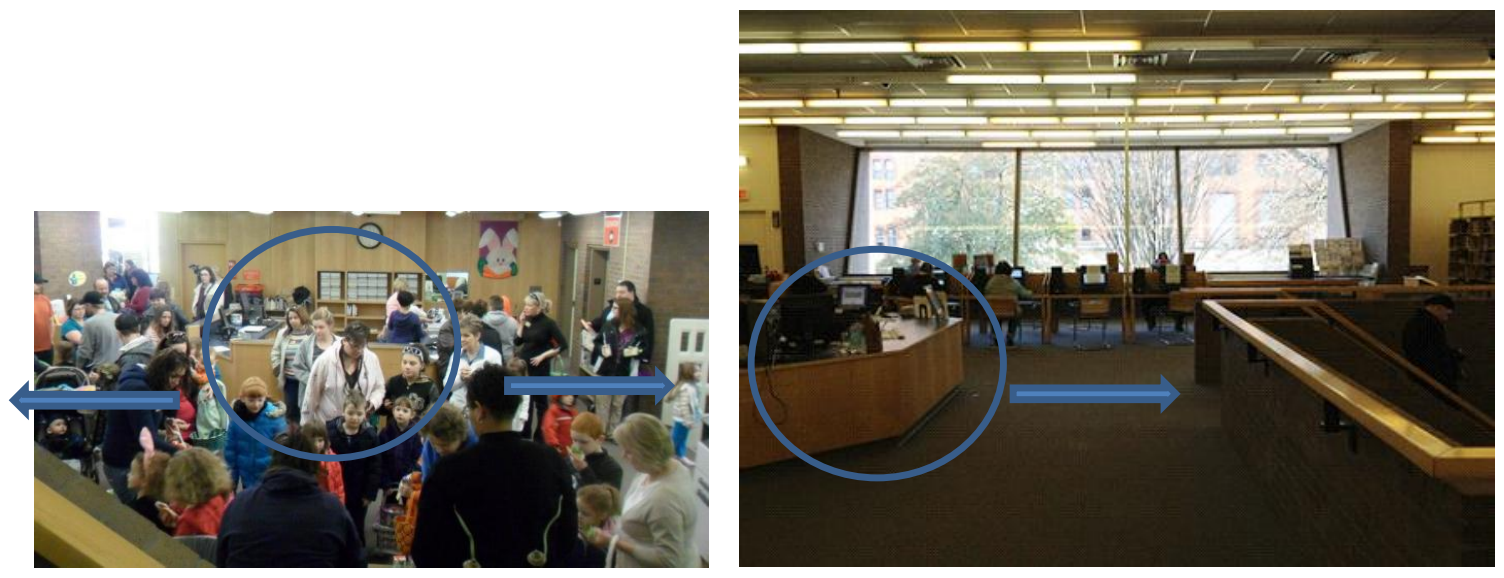

Figure 16: First and second floor help desk besides the entrances.

\section{Windows- Light}

The library's second floor windows are tilted at an angle. ${ }^{69}$ The tilt of the windows gives the building a special character and playfulness. It looks as if the building is facing downward toward the street, watching daily the passersby, trying to catch their gaze and invite them inside. The library's first floor reading rooms have large horizontal window walls that bring daylight into the building.

The artificial light also plays a big part in Breuer's design. Breuer lets natural light come into the building during the daytime and after dark the library lights up with fluorescent tube lights installed in the ceiling. Fluorescent tube lights are usually used as the industrial, modern office building lighting solution. Observing the library from West Pike street, due to one point

\footnotetext{
${ }^{69}$ Except for the windows of the office spaces that are located on the northwest side of the building second floor, which have straight windows.
} 
perspective, it looks as if the lights were running into one recessional point. This visual effect brings movement and depth to the building, and makes the building light up after dark.

On the first floor the fluorescent tubes run from east to west on the library ceiling while on the second floor the lights run from north to south. This additional effect of the artificial lighting creates an additional texture like a vibrant net that gives the building tension and horizontal movement (See figure 17).
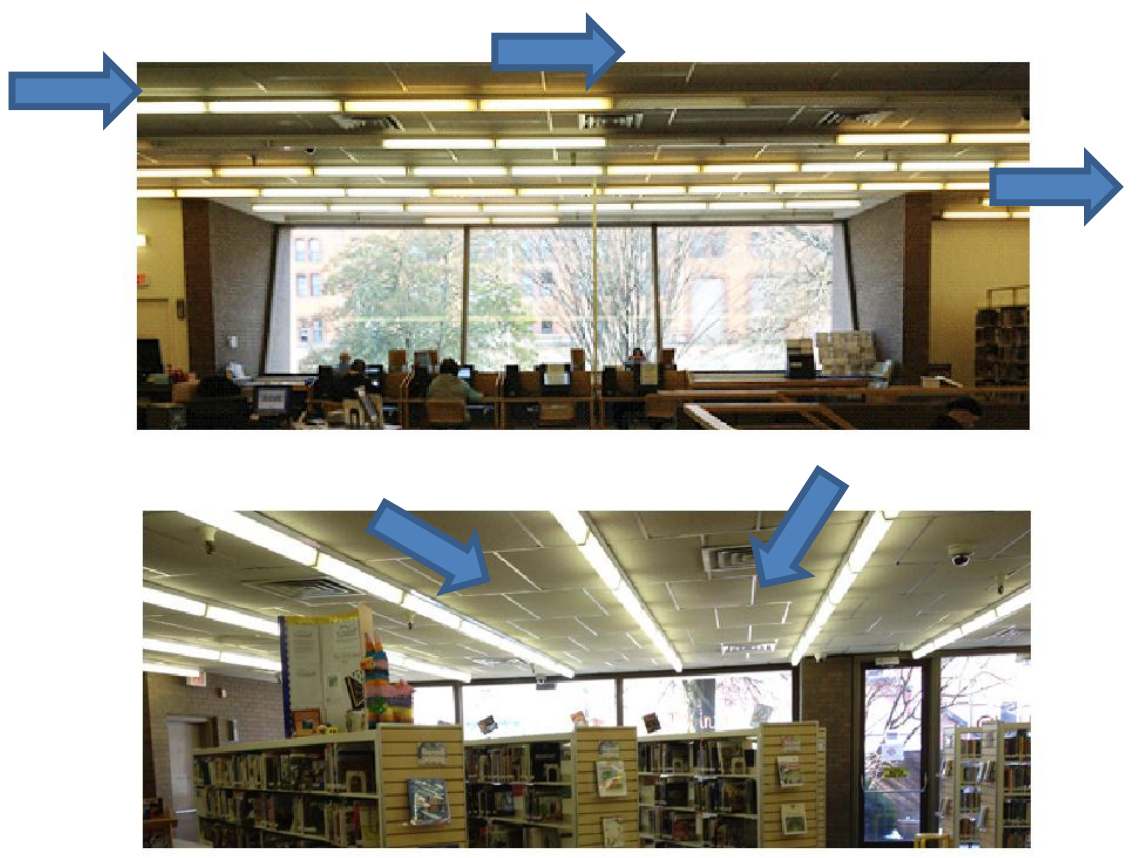

Figure 17: First floor and second floor fluorescent lights running the opposite direction.

One can tell easily that this building is the Public Library of Clarksburg, as the bookshelves can be seen from the outside through the windows and glass walls. On the east side of the building, one can see the old library of Clarksburg, Waldomore, which now serves as the West Virginia Collection (See figure19). From the outside on the east side of the building the 
visitor can see the reflection of the old library in the tilted windows of the second floor (See figure 18).

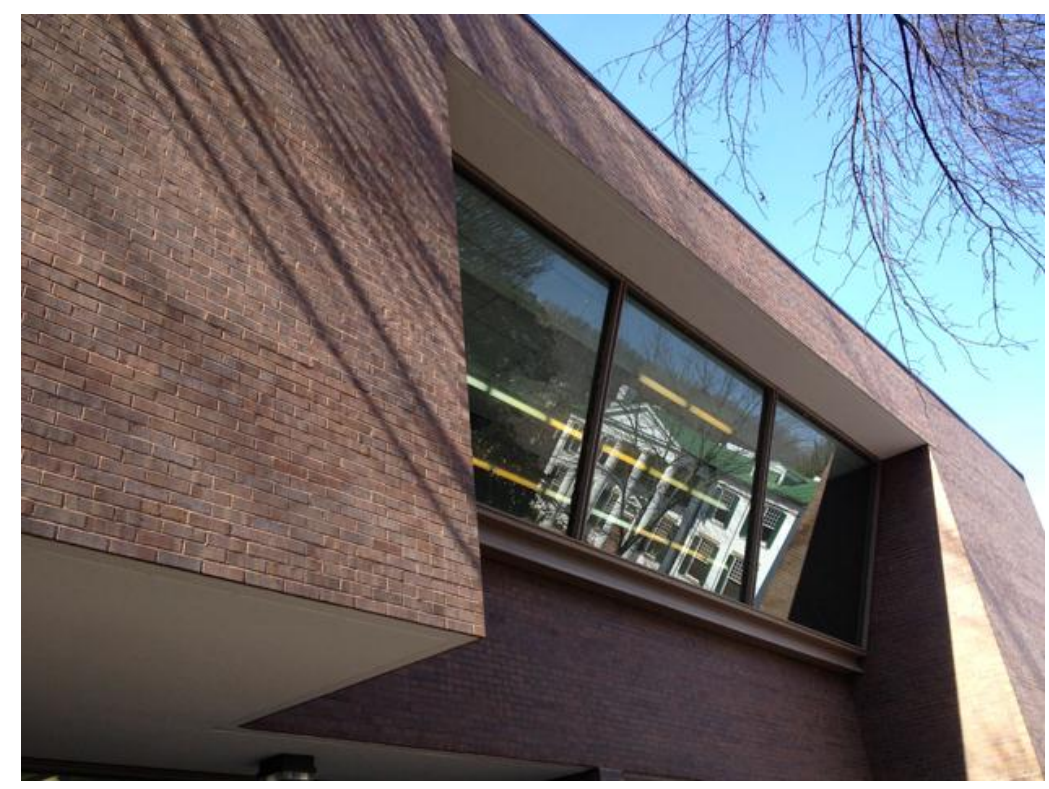

Figure 18: Reflection of the old library in the tilted windows

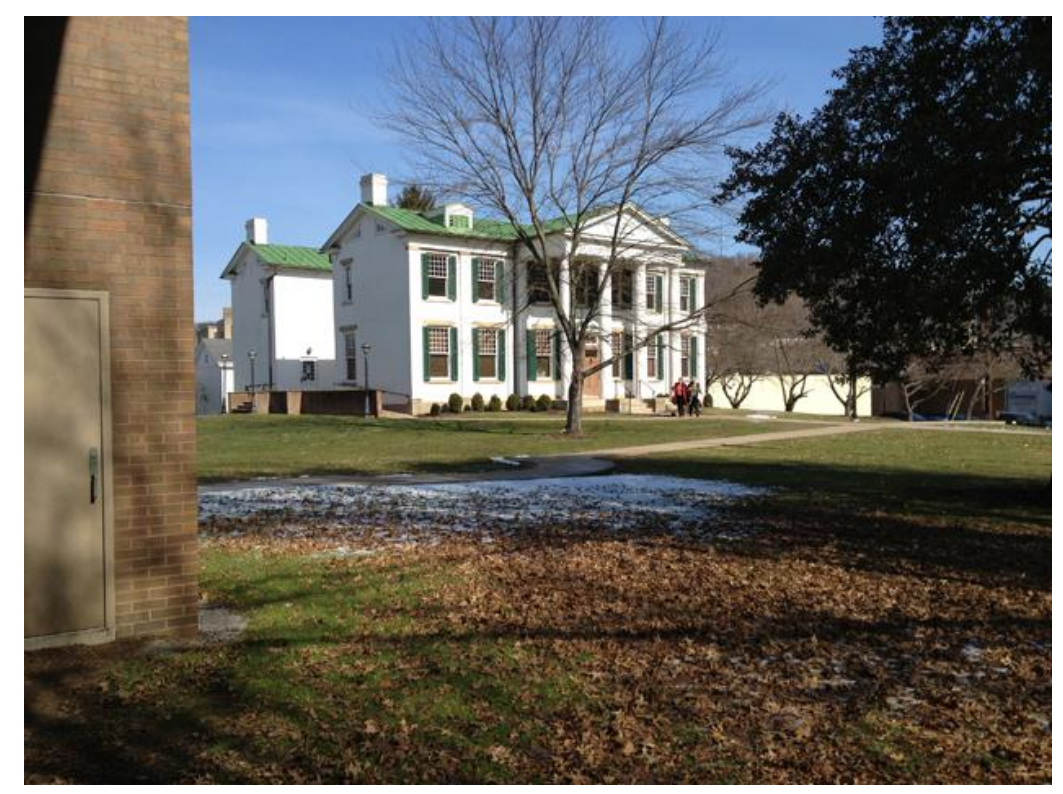

Figure 19: Waldomore, the old library, east to the Breuer building 


\section{Stairs}

The main stairs are placed off-center from the middle of the library, in front of the help desk, which makes the stairs the most prominent part of the interior (See figure 5 and 6). Breuer wrote that "if we could forget about architectural recipes, go back to point zero and from there approach directly the problem of harmonious architecture, we would find a natural mixture of symmetry and asymmetry. We would find that the center of things is the most important zone."70 The main staircase is occupying a large portion of the central area in the library (See figures 6 and 7). The staircase functions as the spine of the building, connecting the two levels and it also lets the light pour in from the second to the first level. ${ }^{71}$ This gives the staircase a glowing quality and gives the public almost an irresistible urge to walk up the stairs. The central staircase functions as a metaphor to emphasize the importance of growing as an individual into one community. Breuer's philosophy of "Sun and Shadow" manifests itself, as the staircase connects the two opposite poles: the individual and the community. Even though the two floors are different in height, they are united by the rays of light from above like rays of knowledge (See figure 20). This staircase is symmetrical and large in the context of this library's size. The monumental design of the stairs provides the visitor a feeling of grandeur, as the visitor walks up the stairs, toward the brightness.

\footnotetext{
${ }^{70}$ Peter Blake, Marcel Breuer: Sun and Shadow, the Philosophy of an Architect (New York: Dood, Mead \&Company, 1956), 10.

${ }^{71}$ In the original plan, Breuer wanted to create skylights to let the natural light come in from above, but today it is only fluorescent tube running through the whole ceiling.
} 


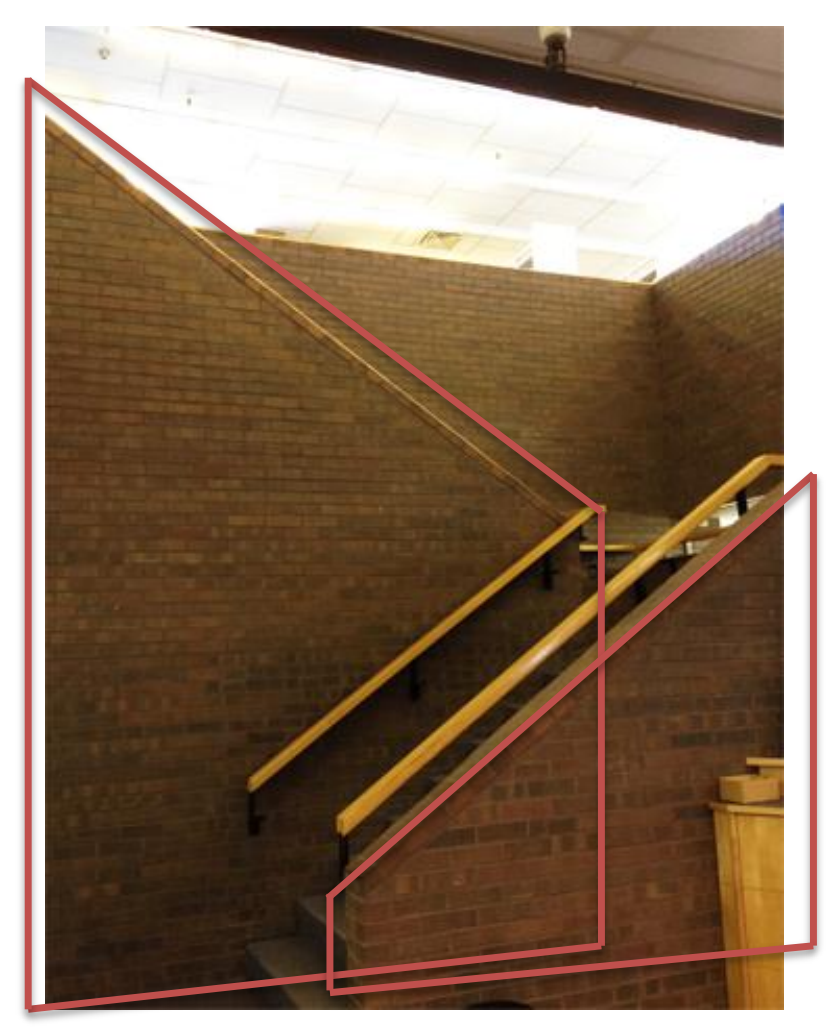

Figure 20: The library staircase.

The staircase is covered with red brick; it is 70 inches wide and has a trapezoidal shape (See figure 20). The trapezoidal shape connects back to the ancient geometric shapes of the Mesopotamian pyramids. Breuer made this ancient connection in the Genesis of Design of 1966 writing, "Construction is indeed a very old human activity, fired and driven not only by practical requirements, but by instincts. We may justly call these instincts atavistic."72 These "atavistic" geometric shapes return in multiple elements throughout the building.

The same pale red colored brick that covers the entire outer façade covers the surface of the staircase; therefore, it links the outer and inner spaces. This indicates the sensation of continuity from the outside to the inside and from the first floor to the second floor. This natural flow of the building is inviting the visitor to explore the entire content of the library, and Breuer

\footnotetext{
${ }^{72}$ Ernyey Gyula, Breuer Marcell- Marcel Breuer Elvek és Eredmények Principles and Results (Pécs: Pro-Pannonia Kiadó, 2008) 82.
} 
achieves this superbly by "paving" the path of the visitor from the outside street all the way to the second floor. This natural flow is also one of Breuer's design concepts that can be found throughout his works. He writes in his the book Sun and Shadow, "We have a new experience of space: space in motion, space in flow." 73

\section{Furniture}

Breuer designed many tables and chairs in the library, where people can learn, research, read and write. As an alternative to reading comfortably in an armchair, one can also sit down at a desk or carrels for more serious work. Today, however, not much of the original furniture remains in the library. The help desks, computer desks, the carrels, armchairs, as well as shelving units were replaced. One of Breuer's original designs that is still used today, are the "Cesca" chairs, the tubular steel cantilever chairs (See figure 21). This chair was one of the most popular designs of Breuer, originally developed in the 1928 for mass production (See figure 22). It was common for Breuer to reuse this particular chair in different house design interiors. The feeling of a second home is thus emphasized in the details: Breuer has the same "Cesca" chairs at his own home, at the Breuer House- New Canaan I, New Canaan, Connecticut (See figure 23). In order to achieve maximum effect Breuer designed the library's entire interior and exterior space.

\footnotetext{
${ }^{73}$ Peter Blake, Marcel Breuer: Sun and Shadow, the Philosophy of an Architect (New York: Dood, Mead \&Company, 1956), 60.
} 

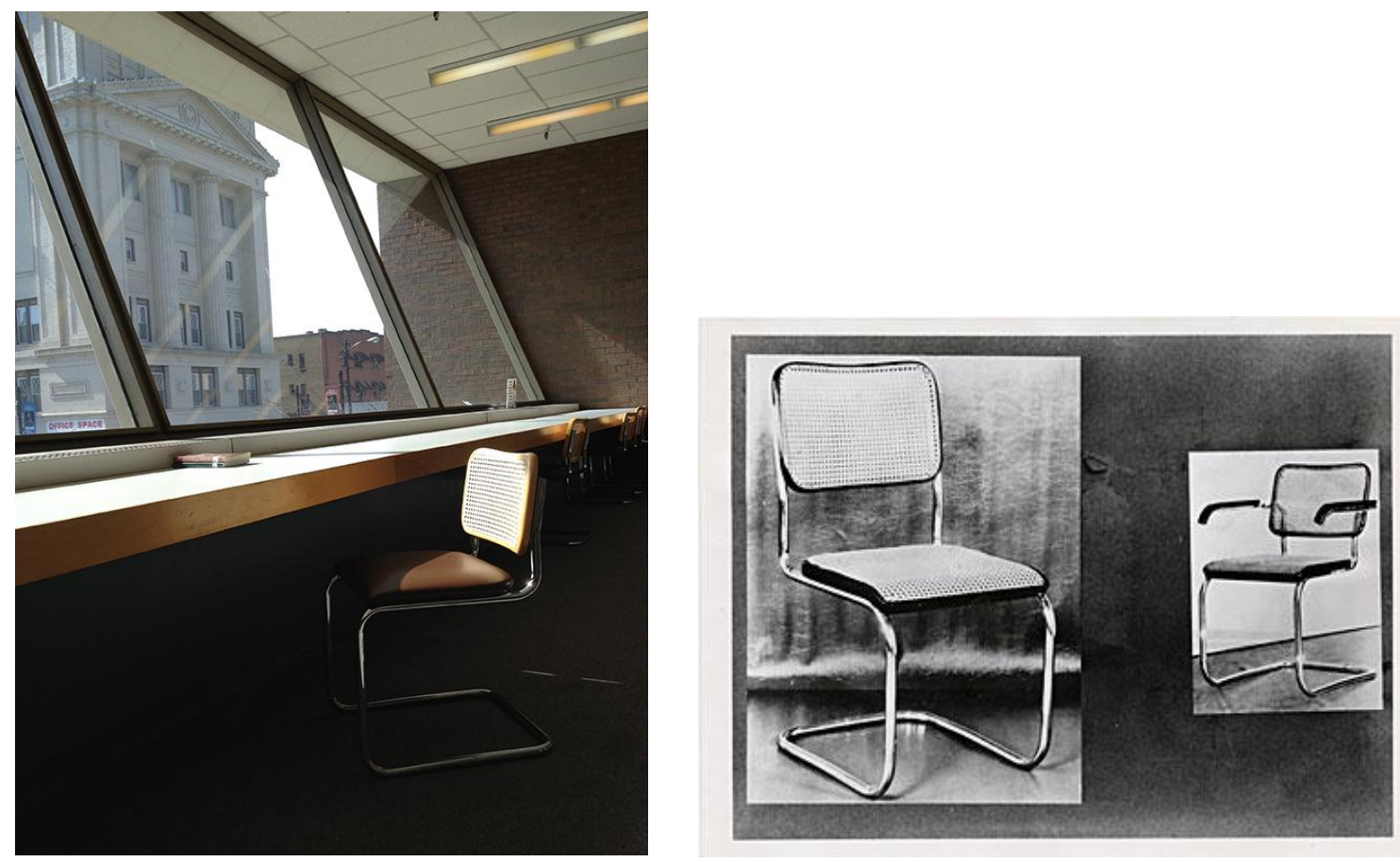

Figure 21 and 22: Tubular steel cantilever "Cesca" chairs with bent-wood frame. Left photograph taken in the library and on the right is a photograph of the original "Cesca" chairs, 1928.

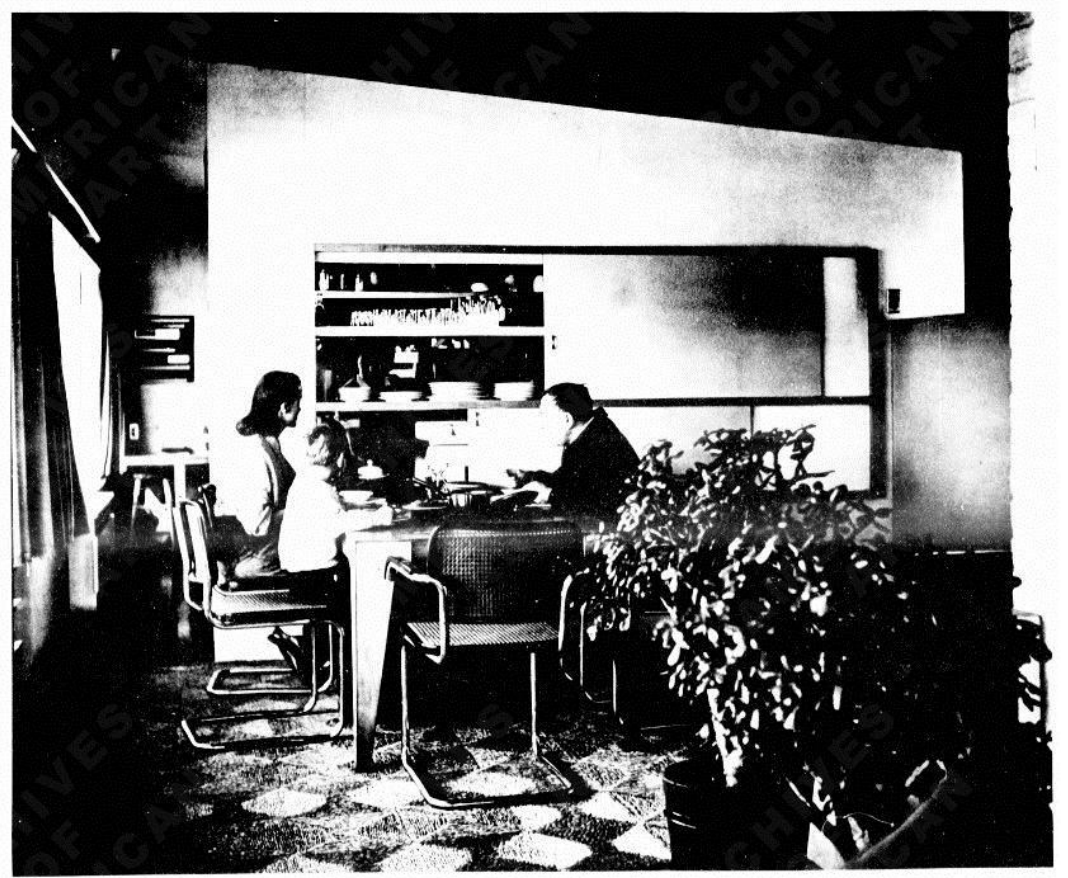

Figure 23: Breuer House- New Canaan I, New Canaan, Connecticut, 1947-48 interior with "Cesca" tubular chairs. 
In the beginning Breuer and his Associates were only contracted to design the structural building itself, later the Board of Directors of the Clarksburg Public Library asked Breuer to design the interior space of the library as well. After they turned to Breuer with the need to design the interior of the library, Breuer replied in the following manner:

The cost of the furnishing for the library can vary substantially depending on the character and quality of the materials selected and of the unpredictable course of current inflation trends. A figure of $\$ 70,000$ represents the minimum end of costs range which could easily go as high as $\$ 100,000$ or more- carpeting not included, we are aware of the need to be as economical as reasonably possible. At the same time we doubt that you would turn to us in the matter if you were going to be satisfied with nothing more than a completely routine solution throughout. ${ }^{74}$

The Gesamtkunstwerk or "total work of art" manifests itself in almost all of Breuer's buildings as Breuer usually designed the entire interior and exterior including the furniture and the accessories that come with the house or building. Breuer combined all areas and disciplines of the arts and crafts to establish the same aesthetics and functional quality throughout his designs. Breuer said in one of his interviews in 1972, "Not always but most of the time the house, the building was designed in one process together with all the furnishing of the building. This way of course we could reach a certain harmony." 75

\footnotetext{
${ }^{74}$ Contract between Marcel Breuer and Associates, Architects and the Board of Directors Clarksburg Public Library, 30 August, 1974. Smithsonian Online Archive, Marcel Breuer Collection, Series 8: Project Files, 19221-1986 (Boxes 13, Reels 5724 Frame1346-47) http://www.aaa.si.edu/collections/container/viewer/Letter-and-contracts179643.

${ }^{75}$ Smithsonian Online Archive, Marcel Breuer Collection, Transcripts: Transcripts of interview of Breuer by television reporter István Kardos, 1972, (Box 6, Reels 5718 Frame 508-530), http://www.aaa.si.edu/collections/container/viewer/Transcript-of-interview-of-Breuer-by-television-reporterIstv\%C3\% A1n-Kardos--179410.Translated from original Hungarian to English by the author.
} 


\section{Inner space of the library}

Breuer started his essay The Art of Space in the book Sun and Shadow with a quote from Tao Te Ching, "Though doors and windows may be cut to make a house, the essence of the house is in the emptiness within it". ${ }^{76}$

For Breuer the space was "hollow", "negative" connected to the absolute and the "infinite space". ${ }^{77}$ The connectedness of the inner spaces in Breuer's design had a significantly important role. This connectedness made his spaces so easily navigable and readable. There are no hidden surprises; his space flows from one into the other with no barriers or distractions. Breuer writes about space, "It is in motion, connected to the next space and to the next- and to the infinite space." 78 Although the Clarksburg-Harrison Public Library is relatively small, the modern open floor plan and the natural flow of spaces and light allows the place look more spacious and bright.

\section{Gardens}

Breuer creates contrast between the outside and the inside by dedicating an outdoor reading room on each side of the library. On both the northeast and southwest sides of the library there are gardens, which serves as the associate architect of Breuer; Hamilton P. Smith, called them "outside reading rooms", Breuer dedicated one garden to the adult reading room and one to the children reading room (See figure 24 and 25). These two garden spaces are separated from the outside with brick walls to create the feeling of inside and shelter, even though the reader is outside in the fresh air. Although placing a 5'-20" tall brick wall around each garden, Breuer

\footnotetext{
${ }^{76}$ Peter Blake, Marcel Breuer: Sun and Shadow, the Philosophy of an Architect (New York: Dood, Mead \&Company, 1956), 60.

${ }^{77}$ Ibid.

${ }^{78}$ Ibid.
} 
gave the reader partial protection from the outside, as he did not cover the "outside-reading rooms" from above. It is interesting to find that in his library Breuer did not provide sunshades, but he did create a wall around the courtyard. Perhaps this is a manifestation of Breuer's "Sun and Shadow" philosophy, meaning to create a balance between the shadow the reader gets when being inside the building and the sun the reader gets by being in the outside reading room. Just like at the bullring in Spain, Breuer says in his book "half the seats in the bull ring face the sun, the other half is in the shadow... The Spanish sun is not diluted by the Spanish shadow. Both, in their undiluted clarity exist, are part of the same ideal." ${ }^{79}$ The gardens are completely identical; they both carry one sculpture each by a local artist named Bill Hopen, although they were not included in the original plan of Breuer. The two sculptures, however, show the continued dedication and adherence to the city board's original idea of promoting the arts and cultures in the home-like atmosphere. The sculptures are very similar, however one is standing vertically and the other is leaning horizontally. Both sculptures are organic and abstract, the first depicting a mother and a child and the second of a mother with children (See figure 24 and 25).

There is little vegetation in the gardens; they are paved with concrete panels. The trees are planted along the brick wall. Breuer's intention to connect the outside with the inside was implemented by creating two well-protected outdoor reading rooms. In these spaces the reader can enjoy the fresh air and the sun while reading. Hamilton Smith wrote about the gardencourtyards the following on February 21, 1975:

[...] the exterior space often becomes an extension of the interior, particularly when a wall element [and materials such as brick] continues from inside out. This approach will be noticed on the Library, we believe, and partly for this reason we

\footnotetext{
${ }^{79}$ Peter Blake, Marcel Breuer: Sun and Shadow, the Philosophy of an Architect (New York: Dood, Mead \&Company, 1956), 32.
} 
were pleased that the Board had the wisdom to retain the garden walls in the face of [a] budget problem. ${ }^{80}$

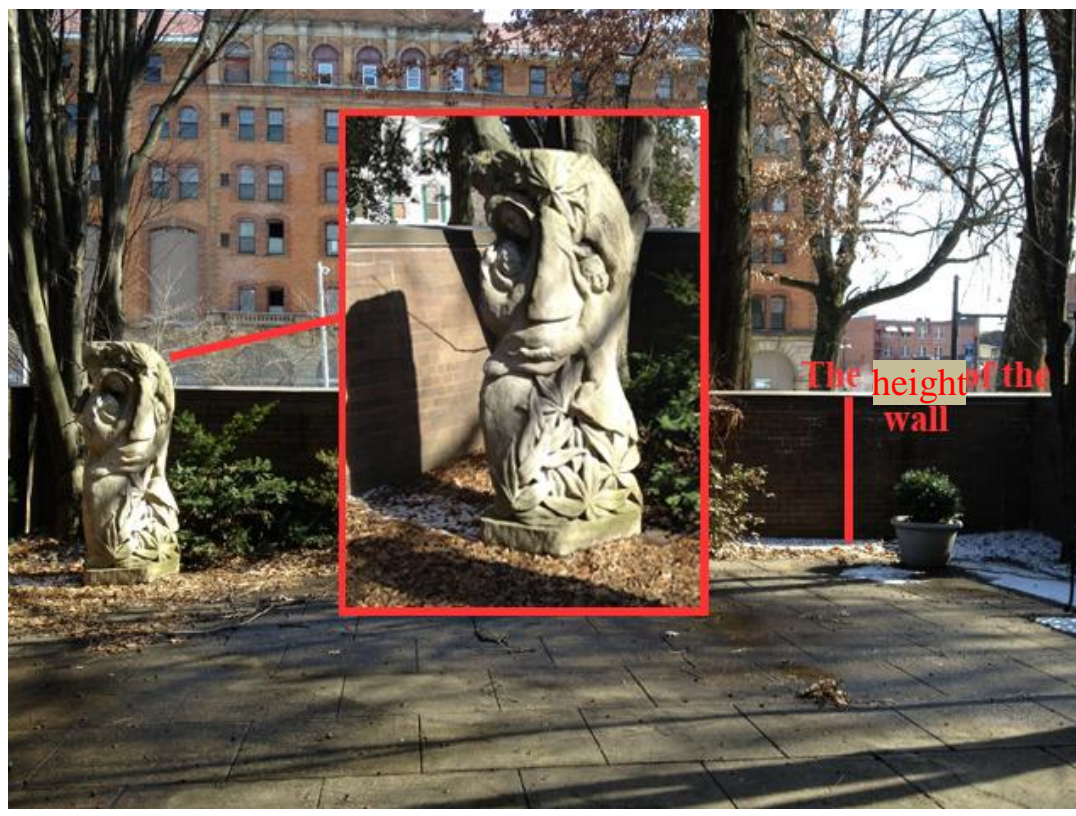

Figure 24: Southwest garden for the adult reading room

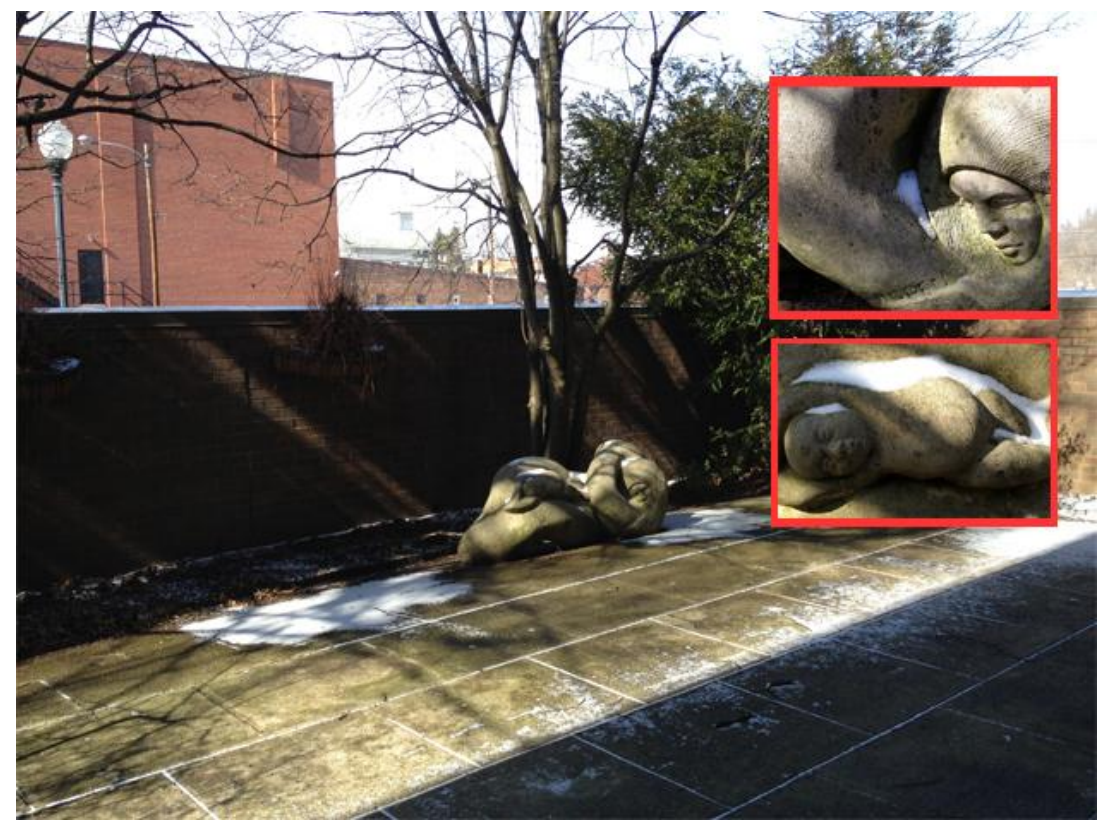

Figure 25: Southeast children's garden for the children reading room

\footnotetext{
${ }^{80}$ Isabelle Hyman, Marcel Breuer, Architect, the Career and the Buildings, (New York: Harry N. Abrahams, INC., 2001), 188.
} 
When the viewer looks at the building from further away, the viewer can notice a distance of 2"-0' between the top of the wall and the end of the first floor (See figure 26). This difference creates a small horizontal window of light that comes through from the inner space of the library to the outside. This opening between the wall of the staircase and the height of the first floor ceiling can be observed and gives the building a playful character; a small opening, where one can peek in and observe the other space (See figure 27). This opening between the walls of the porches and the end of the first floor is also an inviting element of the building that lets the viewer be curious about what is inside this building and further emphasize the horizontal spread of the building.

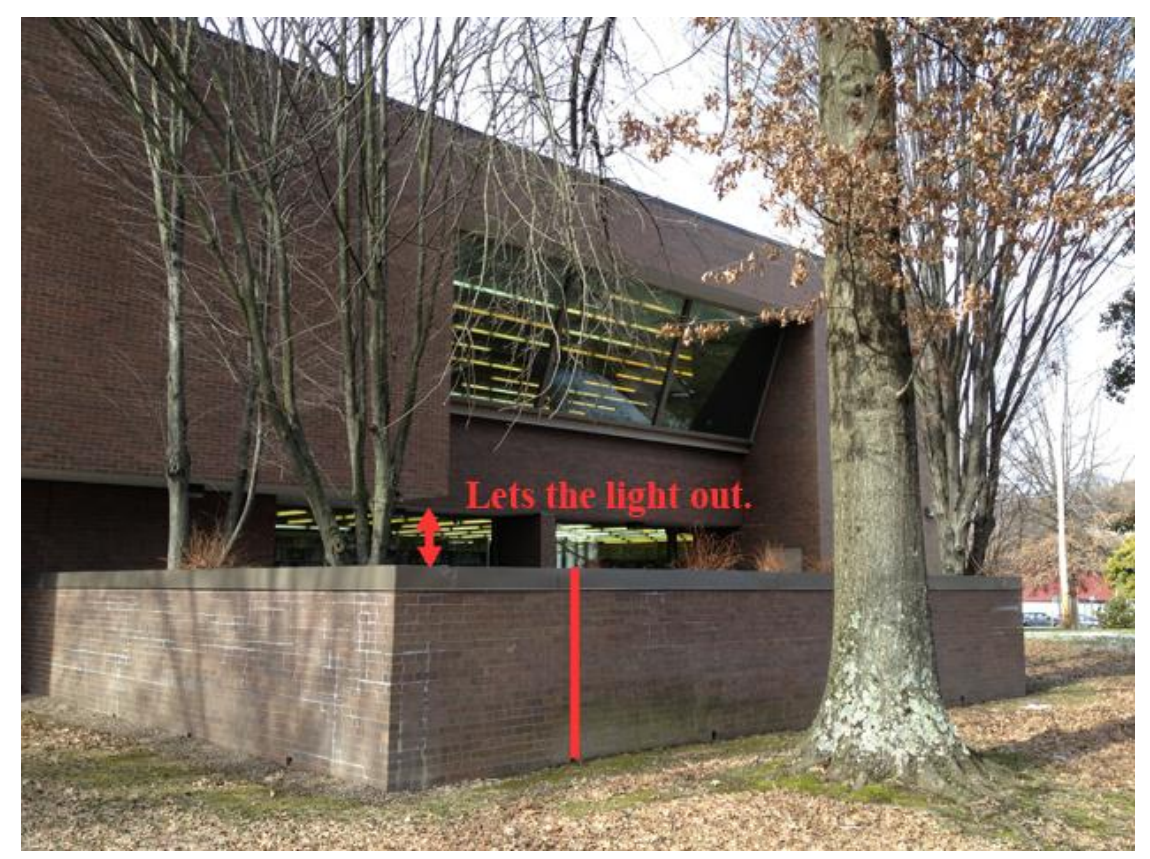

Figure 26: Southwest garden wall from the outside shows opening 


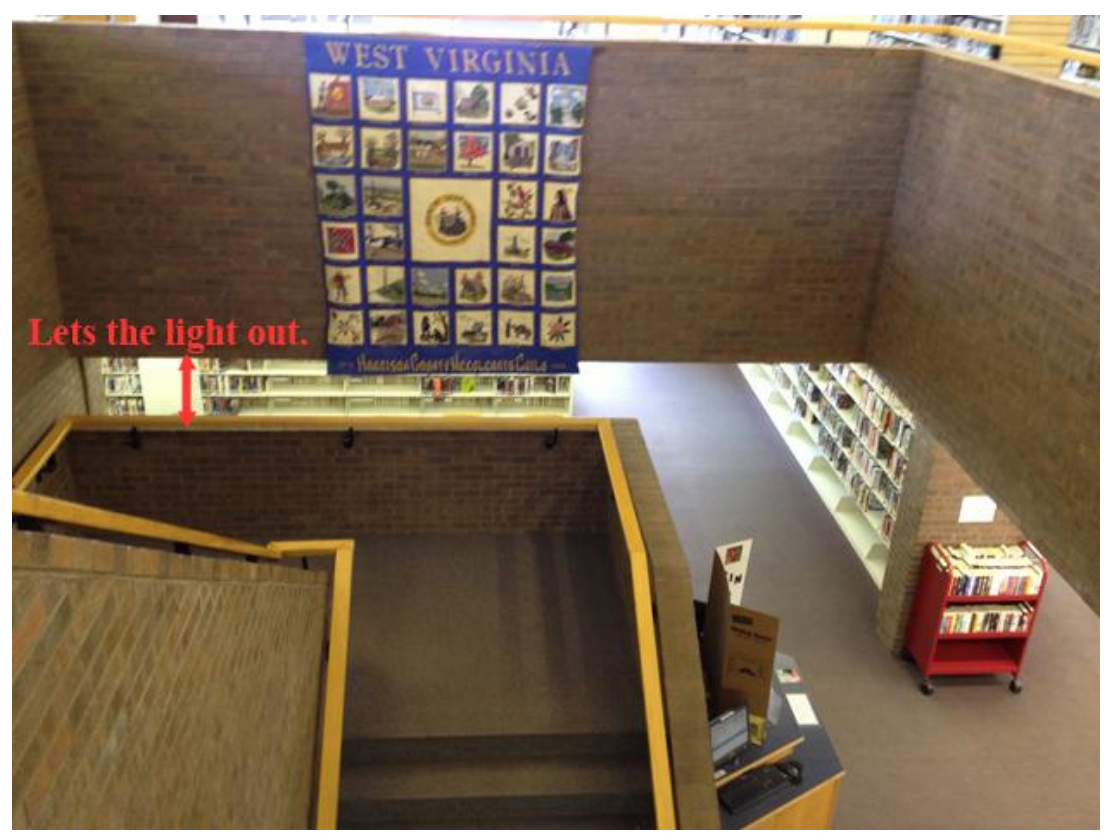

Figure 27: Staircase, wall opening, lets the light come through

\section{Materials}

The building is made from basic materials and standard construction techniques, such as red brick and concrete block walls, dry-wall partitions, and suspended acoustic ceilings. This technique allowed the structure to be built on a modest budget. The red brick exterior and interior walls were chosen as most of the city is built from brick. The brick was purchased and shipped from Pittsburgh.

The problem of harmonizing a new building with another architectural style surrounding it comes up again and again... There are certain means of architecture which can be used as connecting bridges between "styles" or "periods." For instance, the material used for the facing of the building, or a general feeling of scale (large or small scale as the case may be) though even these means of architectural expression should not be used to "harmonize" without realizing the inherent danger of falsification of ideas. ${ }^{81}$

\footnotetext{
${ }^{81}$ Smithsonian Online Archive, Marcel Breuer Collection, Correspondence with Charles W. Millard, JR May22, 1957 (Box 4, Reel 5713, Frame 504), http://www.aaa.si.edu/collections/container/viewer/-179172.
} 
The library with its top-heavy appearance brings the Whitney Museum to the viewer's mind. Breuer and his associates wanted to create more than just a library; they wanted to create a home, a shelter to cultivate the mind that everyone can use, just like they created a shelter for the arts at the Whitney Museum. This similarity will be further discussed in the following chapter. Breuer's architectural firm intentionally created a modern and functional space that melted in with the materials of the rest of city; therefore this building was made of brick and not concrete walls.

Breuer and his associate, Hamilton P. Smith made an effort when designing the Clarksburg-Harrison Public Library to tie the building back to its environment and its historical past. As all the buildings on the site are constructed from brick, Breuer chose brick for the library's building material. However, with the modern top-heavy, flat roof, geometric shape, Breuer managed to make a clear statement about Clarksburg's present and future. The library was built by standardized building methods and construction techniques; however Breuer designed unique details to emphasis the symbolic meaning of the building, to bring together Clarksburg's community. 


\section{CHAPTER THREE}

\section{Breuer's Large Scale Works}
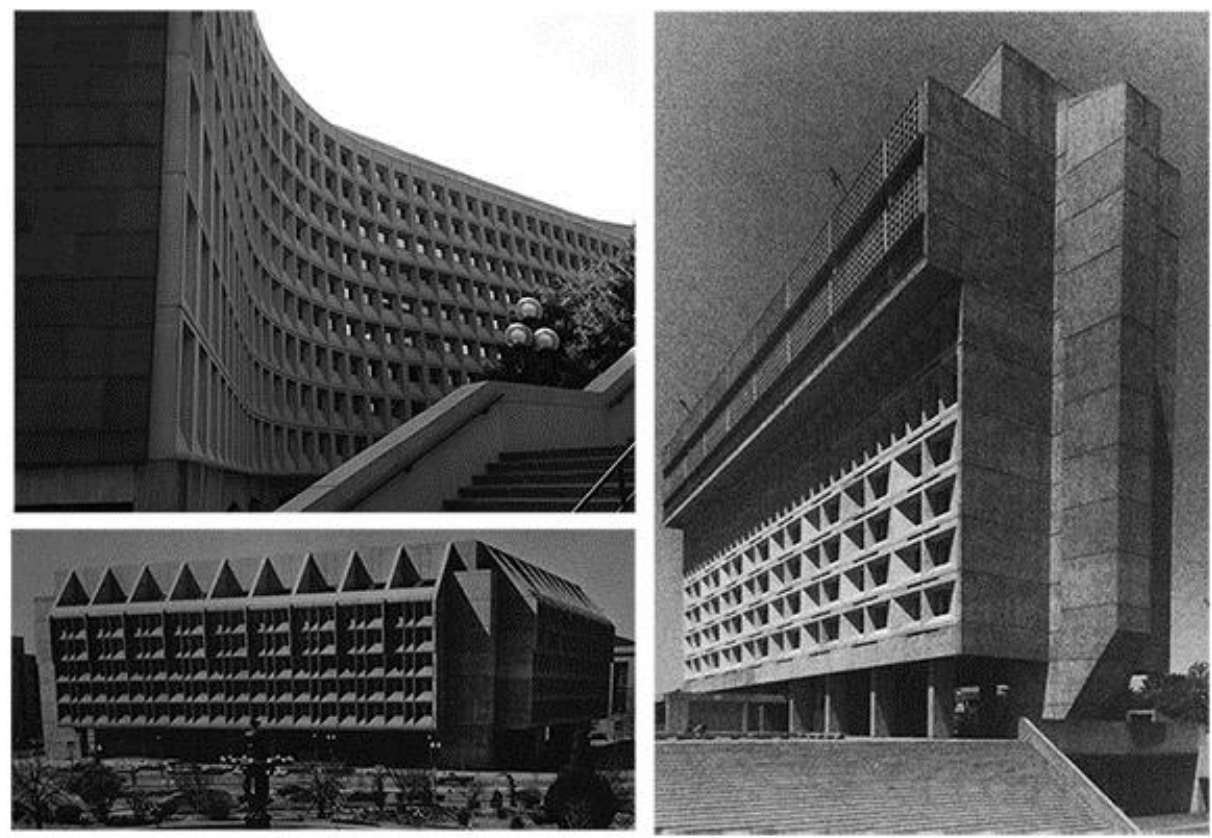

Figure 28, 29, 30: Left top: Department of Housing and Urban Development (HUD) Washington D.C. Left bottom: Department of Health and Human Services Headquarters, Washington D.C. Right: University of Massachusetts, Murray Lincoln Campus Center and Garage, Amherst, Massachusetts.

Breuer received his first large scale commission in 1950, when he was asked to design a new dormitory for the Vassar College, and a few years later, in 1955, when he was chosen to design the UNESCO Headquarter building in Paris. Breuer's most successful period lasted from the mid-1950s until his retirement in 1976. In this last period, Breuer's primary focus was to design large scale works. These large scale buildings transformed Breuer's design to a more monumental, symbolic and sculptural architecture. Among the many large-scale designs of Breuer were; Department of Housing and Urban Development (HUD) Washington D.C.(1968) (See figure 28), Department of Health and Human Services Headquarters, Washington 
D.C.(1977)(See figure 29), University of Massachusetts, Murray Lincoln Campus Center and

Garage Amherst, Massachusetts, (1967-70) (See figure 30).

Cranston Jones writes about Breuer's late work:

Since the late forties, the scope of his work has changed to large project, public building, and to the planning of whole communities in the U.S., in Europe, and in South America. Side -stepping specialization, his practice includes educational buildings, colleges, commercial, industrial, and office structure, hotels, apartments, houses (as an opportunity for individual experiments); religious, governmental, and engineering buildings; recreational facilities, monument, space sculptures, theaters and museums. ${ }^{82}$

Heavy, thick concrete walls, small, deep windows, textured façade and symmetry combined with asymmetrical compositions dominated in Breuer's large-scale works. K. Michael Hays describes Breuer's large-scale designs in the book, Whitney Museum of American Art the following way: "His was a late-modern architecture that was sculptural, brooding, and slightly enigmatic, more open to monumentality and symbolism than its predecessors- even if ambivalently so- but still committed to clarity of structure and function. ${ }^{83}$ Breuer's forms were shaped by function and by the building's relationship to the surrounding environment. Breuer gave much attention to what the needs of the patron or the community was. Breuer was rather "sculpting" than "building" his abstract concrete structures. Breuer's expressionist approach of building public spaces was very similar to Le Corbusier's late architectural developments, such as the Notre Dame de Haut, the works of Oscar Niemeyer, Eero Saarinen and the works of Louis Kahn.

\footnotetext{
${ }^{82}$ Smithsonian Online Archive, Marcel Breuer Collection, Articles and Books by Others: Typescript with annotations by Breuer, (Box 7, Reels 5719 Frame 263), http://www.aaa.si.edu/collections/container/viewer/ Typescript-with-annotations-by-Breuer-179479.

${ }^{83}$ Ezra Stoller, Whitney Museum of American Art, (New York, Princeton Architectural Press, 2000) 1.
} 
Marcel Breuer's ultimate success of designing the Whitney Museum of American Art in New York (1964-66) spread Breuer's good reputation throughout the United States and brought him multiple other major institutional museum and library commissions, such as the Cleveland Museum of Art Education Wing, Cleveland, Ohio (1968-70), the Clarksburg-Harrison Public Library, Clarksburg, West Virginia (1974-75) ${ }^{84}$, and the Atlanta Central Public Library, Atlanta, Georgia (1980). ${ }^{85}$ Choosing the creator of the Whitney Museum of American Art to design the new building for the Clarksburg-Harrison Public Library in West Virginia was a strong statement to rehabilitate Clarksburg's community and to add to the city an additional cultural heritage for which Clarksburg hoped it would always be remembered.

Beside the public cultural and educational purposes of the Whitney Museum, the Cleveland Museum of Art Education Wing, the Clarksburg-Harrison Public Library, and the Atlanta Central Public Library, these buildings share many similarities; therefore this chapter will explore the similarities of these buildings with the Clarksburg-Harrison Public Library. These buildings were not only created within a relatively close timeframe, but they Breuer designed them together with the same associate architect, Hamilton P. Smith. In all these designs Breuer manifested the unique quality of creating modern spaces that symbolized the individual and the community at the same time. These buildings were created to help the individuals to feel at home, grow intellectually and connect with their community. It is important to investigate these buildings as they share these similar social values. The reason that the Clarksburg-Harrison Public Library Board commissioned Marcel Breuer is the fact that he proved the ability to create

\footnotetext{
${ }^{84}$ The Clarksburg-Harrison Public Library was a new addition to the old public library called: Waldomore in Clarksburg.

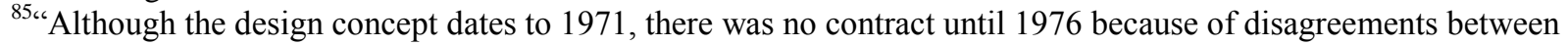
the library administration and the city government with regard to a bond referendum needed to raise funds for the construction and to other controversial issues. Construction finally was begun in October 1977 and was completed in May 1980." - Isabelle Hyman, Marcel Breuer, Architect, the Career and the Buildings (New York: Harry N. Abrahams, INC., 2001), 137.
} 
an intimate space for the community in his previous works, where the citizens could bind together. I would like to explore my hypothesis by investigating (comparing and contrasting) first the buildings: the Whitney Museum, and the Clarksburg-Harrison Public library's structural elements, and in the second part of this chapter to compare and contrast the Cleveland Museum of Art, Education Wing with the Clarksburg-Harrison Public Library.

\section{Case Study 1: The Whitney Museum of American Art, New York, NY, 1964-1966.}

Marcel Breuer and his associate architect, Hamilton P. Smith, were asked to design for the first time in their career a building in New York City. The Whitney Museum was the first new museum building erected in New York that was dedicated as a whole to American Art. The five-story new building for the Whitney Museum of American Art was built on the corner of Madison Avenue and the Seventy-Fifth Street in Manhattan (See figure 33). The agreements were signed to design the museum in July 1963, construction started in September 1964, and the building was completed in August 1966. Breuer writes of the Whitney Museum Project at his Comments at the Presentation, November 12, 1963:

What should a museum look like, a museum in Manhattan? Surely it should work, it should fulfill its requirements, but what is its relationship to the New York landscape? What does it express, what is its architectural message? It is easier to say first what it should not look like. It should not look like a business or office building, nor should it look like a place of light entertainment... It should transform the vitality of the street into the sincerity and profundity of Art. ${ }^{86}$

This writing clearly demonstrates Breuer's functional design approach and his concerns for the surrounding environment of the building.

\footnotetext{
${ }^{86}$ Smithsonian Online Archive, Marcel Breuer Collection, Speeches and Lectures by Breuer: Typescript of speech at the presentation of the Whitney Museum of American Art, 1963(Box 7, Reels 5718 Frame 1184-1193), http://www.aaa.si.edu/collections/container/viewer/Typescript-of-speech-at-the-presentation-of-the-WhitneyMuseum-of-American-Art--179444/.
} 
The Whitney was the second museum in New York to showcase modern and contemporary art works, just few years after the Guggenheim Museum was built in 1959. Frank Lloyd Wright's museum design may have influenced the Whitney Museum's design, as Breuer chose the same top-heavy form to create the new home of the modern art collection. This "inverted pyramid", 87 as Breuer calls the building's shape is also the reverse of the early New York skyscrapers' that had to follow the "setback laws" of New York City. Maxwell L. Anderson writes about the building in the book Whitney Museum of American Art, "The Whitney's blocky new building stood the status quo on its head using the vernacular of Mesopotamian antiquity - the ziggurat- to question the received architectural wisdom of the contemporary era." 88 However, the design decision to use large overhanging cantilevers to expand the gallery space on the top levels solved the technical problem of creating more exhibition space on a very small footprint on a corner lot of downtown Manhattan. ${ }^{89}$ Breuer enlarged the gallery spaces of the museum not only by designing overhanging cantilevers that were projecting toward the street, but also by increasing the different galleries' height (See figure 31). ${ }^{90}$ This made it possible for the large scale modern and contemporary art collection to have the best display.

The abstract, top-heavy, "Cyclopean" ${ }^{91}$ building stands out among the light-weight, high, glass curtain walled, and corporate skyscrapers that can be found near the site. Breuer designed

\footnotetext{
${ }^{87}$ Smithsonian Online Archive, Marcel Breuer Collection, Speeches and Lectures by Breuer: Typescript of speech at the presentation of the Whitney Museum of American Art, 1963(Box 7, Reels 5718 Frame 1184-1193), http://www.aaa.si.edu/collections/container/viewer/Typescript-of-speech-at-the-presentation-of-the-WhitneyMuseum-of-American-Art--179444.

${ }^{88}$ Ezra Stoller Whitney Museum of American Art, (New York, Princeton Architectural Press, 2000), vii.

${ }^{89}$ The Whitney Museum of American Art was built on a 76,830- square-foot land.

${ }^{90}$ Fourth Floor: 17'-6" inches. Third Floor: 12-'6". Second Floor: Main gallery: 12'-10”, Bach gallery: 14'-4,5" inches. Lobby Gallery: 12'-10,5"- Stoller, Whitney Museum of American Art, (New York, Princeton Architectural Presas, 2000), building Specifications.

${ }^{91}$ Ezra Stoller Whitney Museum of American Art, (New York, Princeton Architectural Press, 2000) 7.
} 
a landmark by creating a unique space, a shelter, a home and sanctuary for the arts on the busy streets of Manhattan. The overall budget of $\$ 6,000,000{ }^{92}$ allowed the concrete building to have an unpolished granite façade and luxurious interior finishes, using architectural bronze in the elevator doors and glass frames. Breuer considered this building as a modern sculpture on its own, as he described the Whitney Museum in his speech at the dedication of the Whitney Museum, in 1963:

The overall granite façade, homogeneous, extending out and over towards Madison Avenue, facing down into the sunken garden with openings which grow out of the surface, with the modulation of the Madison Avenue gap between it and the neighboring buildings, with the granite parapet along the side-walk and with the structural concrete form of the bridge- all this is to form the building itself as a sculpture. However, a sculpture with rather serious functional requirements. ${ }^{93}$

The same top-heavy, "blocky" 94 design features can be recognized in the ClarksburgHarrison Public Library (See figure 31 and 32), and the Atlanta Central Public Library (See figure 35), both of which were designed almost a decade later by Breuer and Smith. Although Breuer used the overhanging cantilevers when designing the Clarksburg-Harrison Public Library, he also included brick pilotis to support the second floor. Breuer's Atlanta Central Public Library design calls to mind the Whitney Museum; however it does not have such a dramatic articulation of the overhanging cantilevers, or the top-heavy appearance as the Whitney Museum or the Clarksburg-Harrison Public Library. K. Michael Hays writes about the library in the book Whitney Museum of American Art:

\footnotetext{
${ }^{92}$ Ibid.3.

${ }^{93}$ Smithsonian Online Archive, Marcel Breuer Collection, Speeches and Lectures by Breuer: Typescript of speech at the presentation of the Whitney Museum of American Art, 1963(Box 7, Reels 5718 Frame 1184-1193), http://www.aaa.si.edu/collections/container/viewer/Typescript-of-speech-at-the-presentation-of-the-WhitneyMuseum-of-American-Art--179444/.

${ }^{94}$ Ezra Stoller Whitney Museum of American Art, (New York, Princeton Architectural Press, 2000), vii.
} 
Blake called it: "Kunstbunker," and an editorial in Art News described it as "a black Crusader Castle among the tearooms and boutiques of Madisonia." Breuer bracketed the site with concrete walls and a moat to fend off the encroachments of the glass-walled skyscrapers sure to come (they never arrived, preservationist sentiments changing as they did). From this space, the building emerged. And emerge is the right word, for the site seems to have been cracked open, allowing the Whitney's Cyclopean head to appear and then focus its attention on the apotropaic purpose of Breuer's summons. ${ }^{95}$

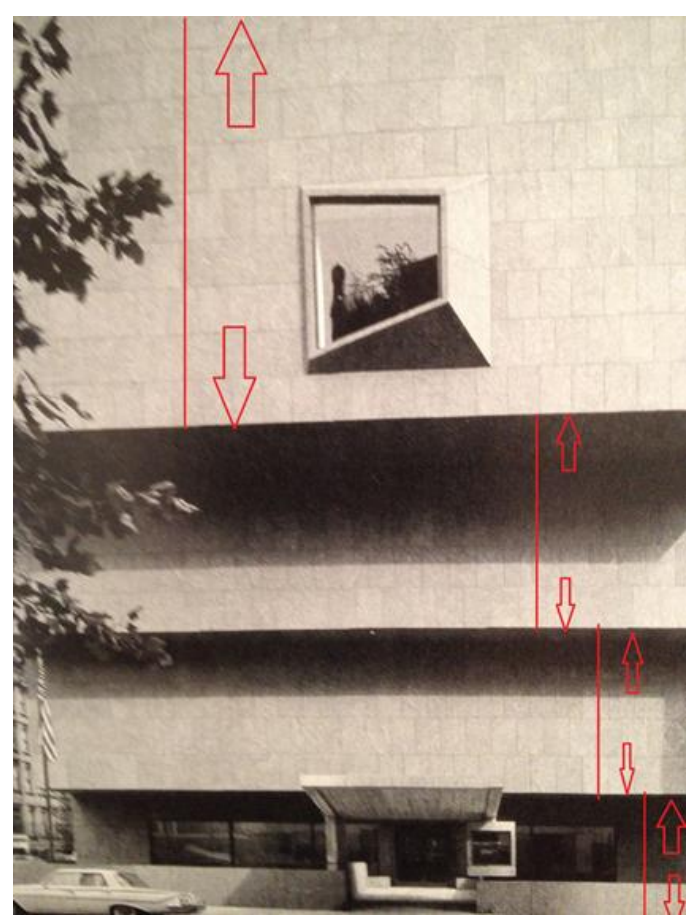

Figure 31

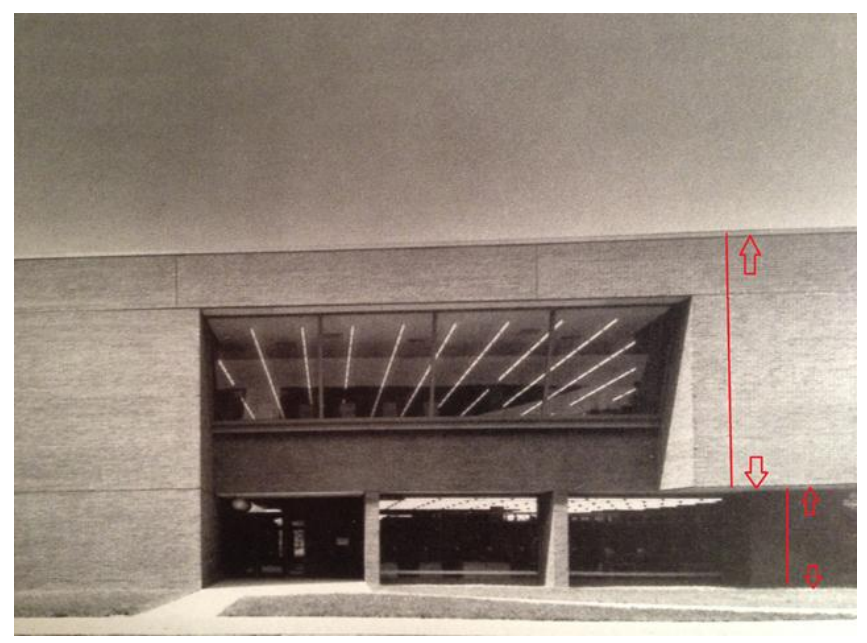

Figure 32

Frontal Façade of the Whitney Museum (Figure 31) and the Clarksburh-Harrison Public Library (Figure 32), showing the top-heavy look of both building.

\footnotetext{
${ }^{95}$ Ezra Stoller, Whitney Museum of American Art, (New York, Princeton Architectural Press, 2000) 7.
} 

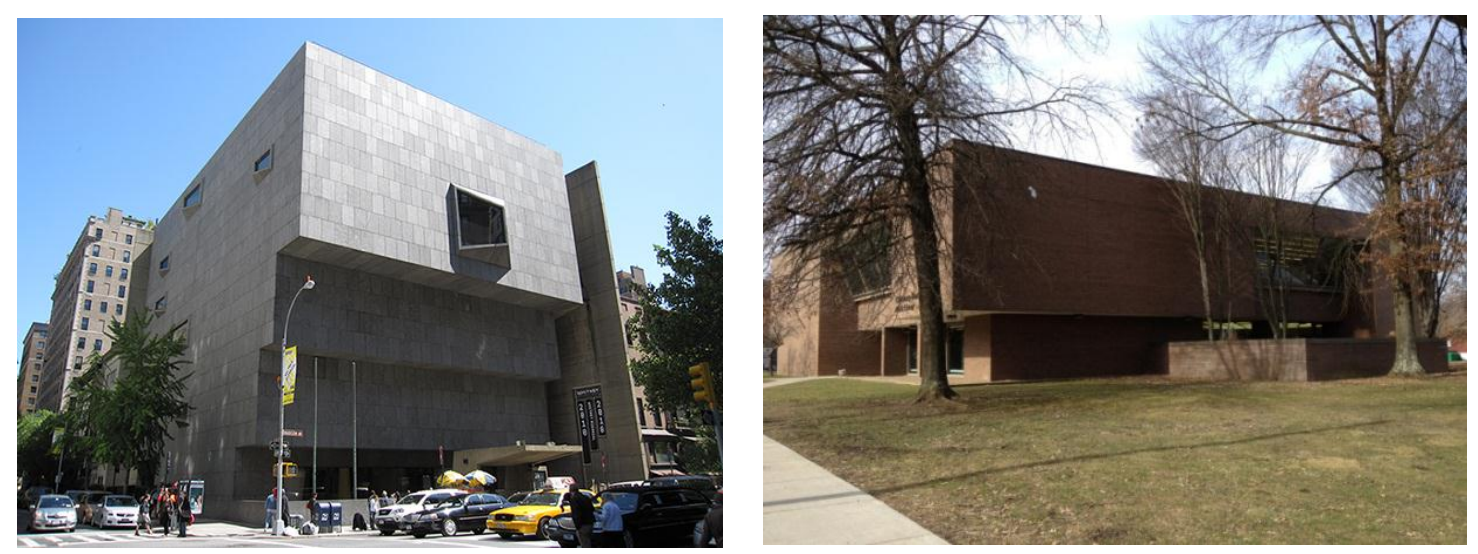

Figure:33 Whitney Museum of American Art (1964-66). Figure 34: Clarksburg-Harrison Public Library(1973-75).
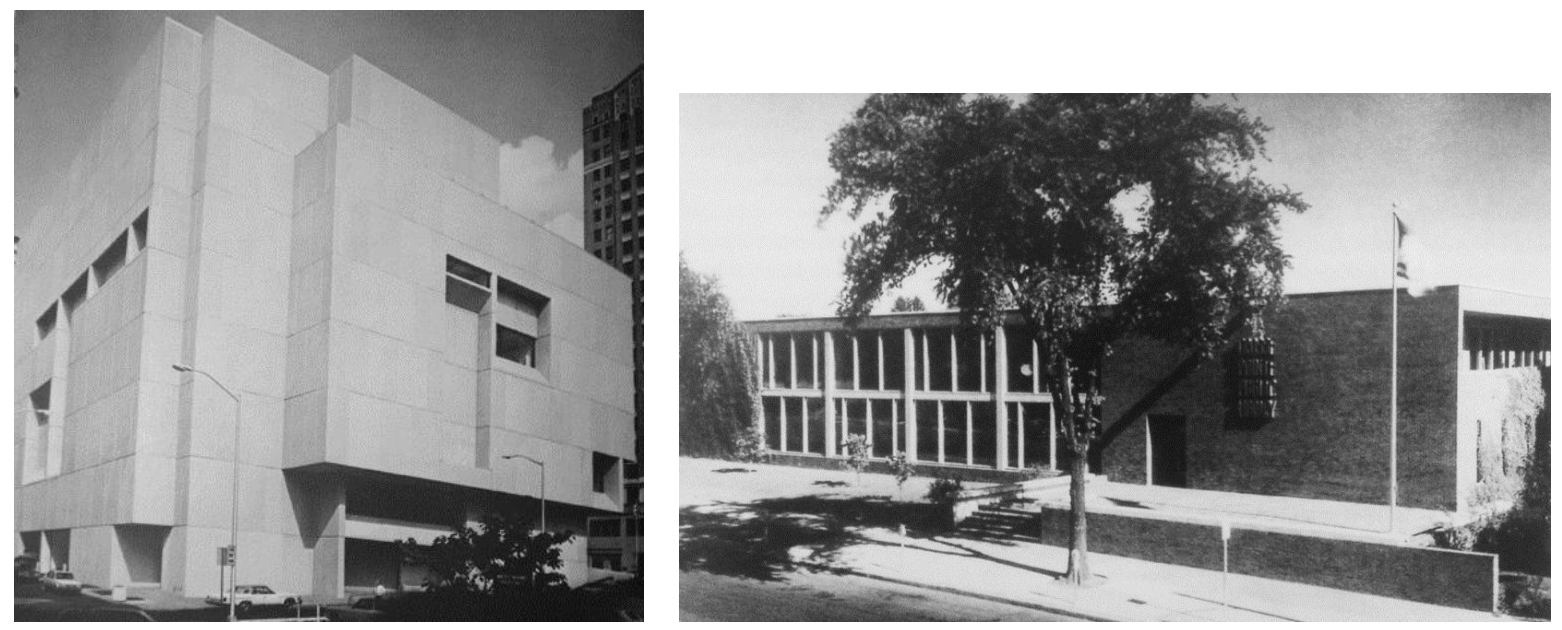

Figure 35: Atlanta Central Public Library, GA (1980). Figure 36: Grosse Pointe Public Library, MI (1951-52).

The massive structures of the Whitney Museum (See figure 33), the Clarksburg-Harrison Public Library (See figure 34) and the Atlanta Central Public Library (See figure 35) remind the viewer of a bunker or a fortress. These buildings are protective shelters, closing inwards and possibly with the intention of turning away from the commercial, noisy and busy streets of the city. In contrast, the Grosse Pointe Public Library, Grosse Pointe, Michigan (1951-52), did not have a closed façade, or a shelter-like appearance (See figure 36). Although the brick wall is juxtaposed by the transparent curtain wall, the transparent windows are dominating the building's façade, rather than the massive walls. 
Even though the Whitney Museum of American Art was constructed from luxurious materials, (granite façade) and the Clarksburg-Harrison Public Library from a modest budget (brick veneer façade) the similarities are apparent. Beyond the obvious similarities of the two buildings' top-heavy look, blocky shape and the other modern architectural features; such as the flat roof, the right-angled geometry, and the lack of applied ornamentation; both buildings function as the public home for art and culture to serve their community. The ClarksburgHarrison Public Library, undoubtedly with its top-heavy appearance and "gazing eye" brings back to the viewer's mind the Whitney Museum (See figure 31 and 32). Both buildings come alive as a result of their unusual, "eye- like" windows. The windows on both building are tilted at an angle. The tilted window of the reading rooms of the library creates a visual effect as if the library was looking at the passersby on the street. This creates a special atmosphere around the building. One can feel the "gaze" of the library from the outside. Breuer makes these building human like, as he gives the building sight. He attributes great importance to the sight as he says in his speech in 1968: "In primitive languages, songs and proverbs, "eyesight" is the most precious possession of a man. ${ }^{, 96}$ Breuer finds the architect's true mission is to give the building a mental and emotional surplus. Breuer continues his contemplation on the rule of architecture in his speech accepting his Gold Medal from the American Institute of Architects, in 1968:

It is as close to our affection as good friends, the family - right there in the center of emotional faith. It is important that we should not be disappointed in them, in our buildings and cities. They are alive, like people.....Architecture should be anchored in usefulness; its attitude should be more direct, more directly responsible, more directly social, more technic-bound, more independent: symmetrical or non-symmetrical. ${ }^{97}$

\footnotetext{
${ }^{96}$ Smithsonian Online Archive, Marcel Breuer Collection, Speeches and Lectures by Breuer, (Box 7, Reels 5718 Frame 1255-1260), http://www.aaa.si.edu/collections/container/viewer/Typescript-of-speech-accepting-GoldMedal-from-the-American-Institute-of-Architects--179450

${ }^{97}$ Ibid
} 
Most of Breuer's large-scale buildings have significantly distinct windows that are emphasized by inlays. These inlays had functional and visually significance, as they provided sunshade, and at the same time became the playground of the sun and shadow on the façade of the building (See figure 39 and 40). However the unique phenomenon of the windows tilted at an angle was a very unique concept that was applied solely at the Whitney Museum and at the Clarksburg-Harrison Public Library (See figure 38 and 39).

In contrast to the Clarksburg-Harrison Public Library, the Whitney Museum has only few windows. This was the result of the slightly different function the two buildings have. A museum does not need as much light as a library; therefore, there is a difference between the number and the scale of the windows in the two buildings. This is how Breuer writes about the windows of the Whitney Museum:

Windows have lost their justification of existence in this building; only a very few remain, and only to establish a contact with the outside. These few openings, free from the strict requirements of ventilation and lighting, can now be formed and located in a free and less inhibited fashion; as an architectural contrast to the strength of the main building lines. ${ }^{98}$
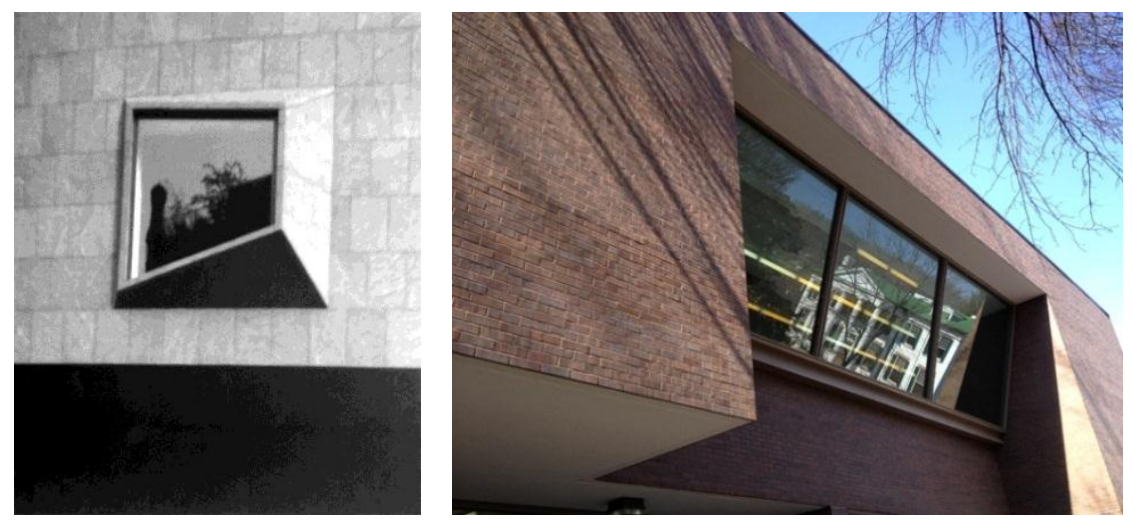

Figure 37: The two tilted angled windows of the Whitney Museum. Figure 38: The two tilted Clarksburg-Harrison

Public Library.

\footnotetext{
${ }^{98}$ Smithsonian Online Archive, Marcel Breuer Collection, Speeches and Lectures by Breuer: Typescript of speech at the presentation of the Whitney Museum of American Art, 1963(Box 7, Reels 5718 Frame 1184-1193), http://www.aaa.si.edu/collections/container/viewer/Typescript-of-speech-at-the-presentation-of-the-WhitneyMuseum-of-American-Art--179444/.
} 


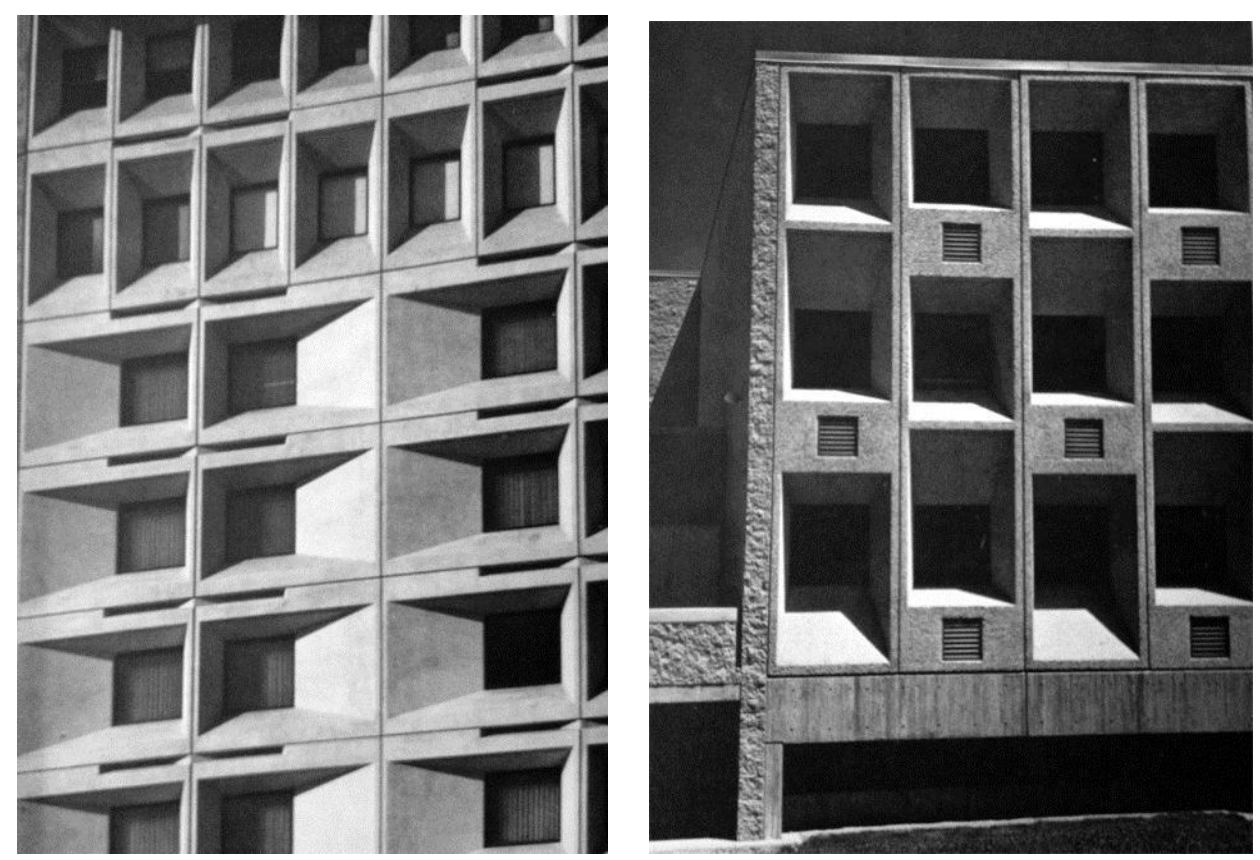

Figure 39 and 40: Murray Lincoln Campus Center University of Massachusetts, Amherst, MA, 1969 and on the right New Campus High School, Roxbury, MA, 1978, Source: Process Architecture, The Legacy of Marcel Breuer

As the Clarksburg-Harrison Public Library Board's original idea was to have a threestory library building, due to their budgetary constraints the Breuer firm devised a reduced program for the library, which resulted in a two-story building. The difference in the height of the two levels of the Clarksburg-Harrison Public Library's exterior is five feet. This difference in height was an attempt to bring back to mind both the piano nobile and also Breuer's house architecture appearance, which will be discussed in the next chapter. Interestingly, Breuer uses the same concept as he used when designing the Whitney Museum, New York, where he created the top-heavy look by adding more height to the upper levels of his building (See figure 41, 42 and 43). "While the average gallery height is 12 '-9" clear, the top gallery height is 17 '-6". The sculpture gallery is double story high, according to the wishes of a number of artists I talked to about this." 99 The functional needs of the museum explain Breuer's formal decisions. The

\footnotetext{
${ }^{99}$ Smithsonian Online Archive, Marcel Breuer Collection, Speeches and Lectures by Breuer: Typescript of speech at the presentation of the Whitney Museum of American Art, 1963(Box 7, Reels 5718 Frame 1184-1193),
} 
question of whether the decision was based on functional need or rather on emotional impact at the Clarksburg-Harrison Public Library remains unclear. The following section drawings show the similar cantilevered structures of the three buildings.

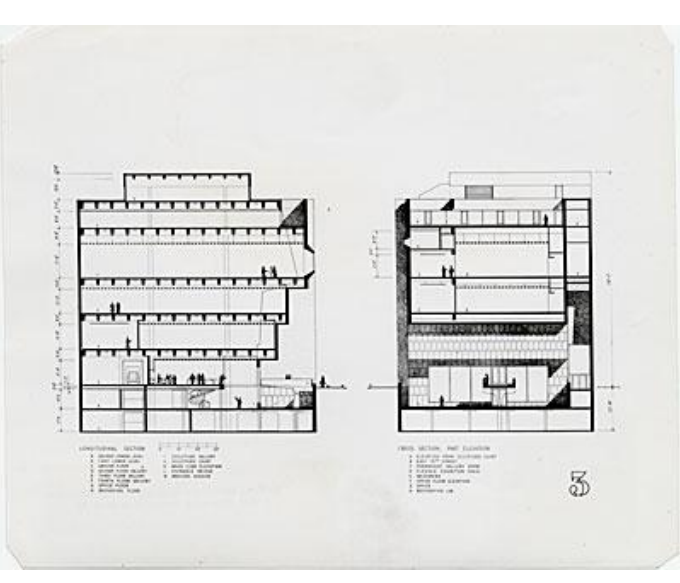

Figure 41: Whitney Museum section drawing

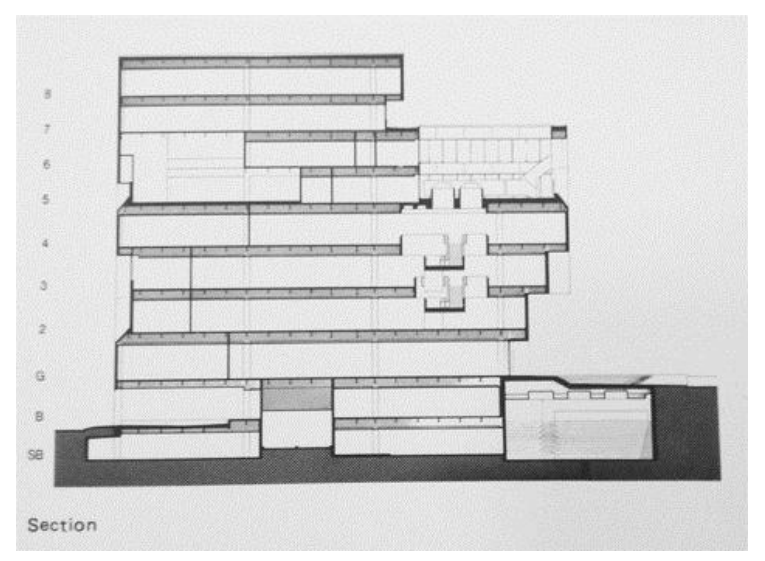

Figure 42: Atlanta Central Public Library section drawing

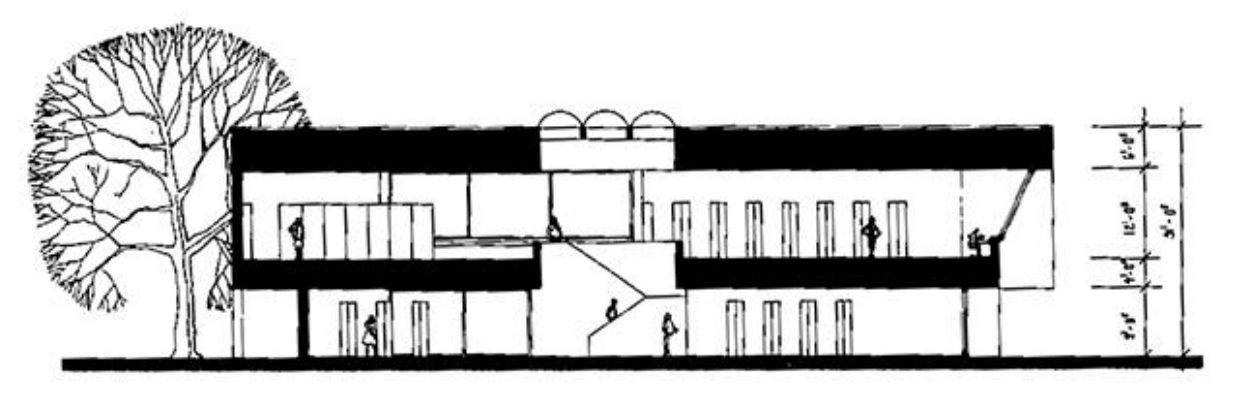

Jtcilat

Figure 43: Clarksburg-Harrison Public Library section drawings

http://www.aaa.si.edu/collections/container/viewer/Typescript-of-speech-at-the-presentation-of-the-WhitneyMuseum-of-American-Art--179444/. 
Gardens were a major element in Breuer's designs (See figure 44); it was the celebration of the outside, the coexistence of the exterior and the interior. Both the Whitney Museum and the Clarksburg-Harrison Public Library have gardens. The Whitney Museum has a sculpture garden between the sidewalk and the building, sunken to the lower level to provide protection from the busy street. There is a connecting bridge where the Museum's main entrance crosses the garden from above, which gives an opportunity to observe the sculptures from a bird's-eye view. It is also a great example to see how important it was for Breuer to create an outside space for the Museum, as he successfully managed to create a garden in such a small lot in New York City. The Clarksburg-Harrison Public Library has two separated gardens on each side of the Library (See figures 24 and 25).

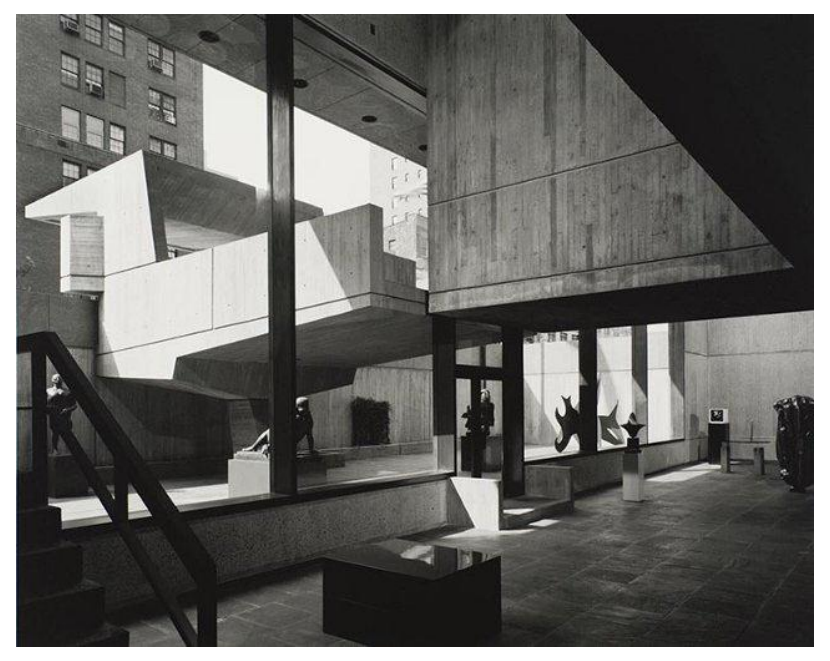

Figure 44: Inside and Outside. The sculpture garden and the entrance bridge in the Whitney Museum.

The Whitney Museum's main entrance can be accessed by crossing over the concrete bridge above the sculpture garden. This allegorical crossing gives the visitors the transforming experience of going from the real, everyday-busy life to a more profound artistic, almost holy experience. The gardens of both the Whitney Museum and the Clarksburg-Harrison Public Library are paved, the vegetation is only limited to a small area beside the wall. 
Despite the many similarities, the Clarksburg-Harrison Public Library's two main entrances carry a different message from the entrance of the Whitney Museum. While the library's entrances communicate equality and openness to every passerby, the entrance of the Whitney Museum has a more monumental appearance, and by placing a bridge in front of the entrance, Breuer evokes a spiritual journey and transformation.

As Breuer believed in the idea that form should follow function, the interior of the Whitney Museum and the Clarksburg-Harrison Public Library are significantly different. The Museum had to be suitable for modern artwork and the library for storing and lending books. This explains why the museum has fewer windows, and the windows are merely small openings. The tilt of the windows brings the attention from the inside to the outside in both buildings and it also brings playfulness into the design.

To conclude, it is fair to say that there are many striking similarities in the design of the two buildings. It is possible that Breuer intentionally designed the Clarksburg-Harrison Public Library very similar to his previous work, the Whitney Museum. Although the Clarksburg city board hoped that by investing in a building built by the world-class architect, West Virginia, and more specifically, Clarksburg would be recognized for its architectural landmark, however the library never got the attention and fame the city board was once aiming for and it is still waiting to be recognized. 


\section{Case Study 2: Cleveland Museum of Art, Education Wing, Cleveland, Ohio}

Marcel Breuer's and his Associate's next Institutional commission right after the Whitney Museum was to create a new addition to the Cleveland Museum of Art, Education Wing, Ohio (See figure 46a). Breuer and his team started the construction on the building in 1968. This chapter exam in what way did the Cleveland Museum of Art, Educational Wind and influenced the design of the Clarksburg-Harrison Public Library. The structural engineer was Paul Weidlinger, from HWH Associates, Inc., mechanical engineer, Edison Price, Inc., lighting consultant, Goodfriend- Ostergaard Associates, acoustic consultant, Turner Construction Company." 100

The three-story Cleveland museum is slightly larger than the Whitney Museum. The overall size of the designed space is more than 110,000 square feet. It was the most expensive art work that the Cleveland Museum ever commissioned. ${ }^{101}$ The total cost of the Breuer addition was more than $\$ 7$ million (even more expensive than the Whitney Museum). ${ }^{102}$ Similar to the Whitney Museum it has a granite façade. Breuer's building was the third addition to the Cleveland Museum. The original neo-classical building was constructed in 1916 and in 1958 the Cleveland architect Paul Ruth expanded the limestone building with a new wing. The construction of Breuer's third addition began in 1967 and was completed in 1970. The museum new wing opened on February 1, 1971.

\footnotetext{
100 “Cleveland Museum's Architectural Acquision: New Education Wing of the Cleveland Museum of Art by Marcel Breuer Forges a Strong Architectural Merger with Two Earlier Buildings," Interiors 130, no. 8 (1971): 110. 101 "Construction of the Education Wing was financed from three general sources: an existing building and development fund, capital funds removed from the Museum's gifted children were added to the Museum's curriculum."- "Art Museum to Open New Education Wing," Cleveland Museum of Art web site, http://www.aaa.si.edu/collections/container/viewer/Press-kit-179903.

102 "The most expensive art object ever acquired by the Cleveland Museum of Art is the new $\$ 7$ million education wing that Marcel Breuer built." Adele Z. Silver, "The New Education Wing Cleveland Museum of Art," Museum International 25, no. 4 (1973): 232.
} 
Breuer saw his new addition as an "integral part" of a series, rather than an addition that echoes back the existing two buildings. Breuer described his intentions when designing the new addition: "To plan a wing that works in its own right, works as an integral part of the total museum, and finds a way to unify the architectural appearances of the three distinct phases of construction." ${ }^{103}$ The new wing gives a home to the Museum's Art History and Education Departments the Music Division, and the Extension Exhibition Departments. The main purpose for creating the new addition in 1967 was to enrich the museum space with an educational function. Breuer's addition is the largest art education building integrated into a museum in the United States. ${ }^{104}$ The building serves an active educational program for children, adults and professionals. A few of the important educational spaces the building holds are a large concert hall, a library, three temporary exhibition spaces, classrooms, and lecture halls. Beside the educational public spaces it also has spaces, such as offices, a truck ramp, a greenhouse and multiple workshops.

From the outside, a large concrete canopy directs the public into the main entrance (See figure 46a and 46b). The canopy takes the public from the two outside parking areas, into the inside lobby area on the ground floor. The canopy is $115^{\prime}-0$ " long and $26^{\prime}-0$ " wide. ${ }^{105}$ The front façades have no windows, the museum's windows and glass walls are located in the inner courtyards that are not seen from the outside. The façade is covered with light and dark gray granite placed vertically, which reinforces the horizontal spread of the building. The change of granite color has a vibrating effect on the eyes, bringing the building to life. This building as do most of Breuer's buildings reminds the viewer of a bunker, as it has a massive box shape.

103 Silver, "The New Education Wing," 232.

104 "Cleveland Museum's Architectural Acquision: New Education Wing of the Cleveland Museum of Art by Marcel Breuer Forges a Strong Architectural Merger with Two Earlier Buildings,” Interiors 130, no. 8 (1971): 108. 105 Adele Z. Silver, "The New Education Wing Cleveland Museum of Art," Museum International 25, no. 4 (1973): 233. 
However, Breuer counterpoints the formal features with its light and free standing screens, terraces and patios, where he connects his structure back to its environment. Therefore, body and light create an illuminating effect altogether.

On the ground floor/main level the visitor finds: the Temporary Exhibition Gallery (98'0" by 88'-0"), lobby, cloakroom, bathrooms, stairways, elevator, sitting area, and Auditorium (two level high). The roof structure of the building is supported by steel trusses, which enable the exhibition gallery spaces and the lobby to be free of columns. Breuer said: “...on entering [a museum], one should see more than the usual lobby landscape...something of the life of the museum must be immediate and visible from the doorway." ${ }^{106}$ On the upper level one can find the office spaces, a small temporary exhibition gallery space, the auditorium, a terrace, library space, and the art history and music department. On the lower level one finds: the education gallery, orientation rooms, classrooms, lecture/ rehearsal rooms and the courtyard.

The auditorium contains 750 seats. ${ }^{107}$ In addition, it also has movable walls and a lighting system. The auditorium provides a wide range of cultural events, from opera, orchestra, dance, and theatre performances to lectures or films. As Breuer tried to design a "happy medium" to serve all vocal purposes, the acoustics of the room proved to be unsatisfactory in the end.

The overall shape of the Cleveland Museum of Art, Education Wing is a blocky horizontal spread similar to the Clarksburg-Harrison Public Library’s shape; however it has a very different design from the Clarksburg-Harrison Public Library. The museum has no piano nobile (second floor has higher ceilings than the first floor), no overhanging cantilevers or pilotis, it has absolutely no window openings on the front façade. Breuer designs an inner patio,

\footnotetext{
106 Ibid., 234-236.

107 It has a ground floor and balcony seating.
} 
which provides the opening for the library and other spaces that need the natural flow of daylight. The Cleveland Museum of Art has a very closed and protected design from the outside, but is very open from the inside (See figure 45 and 46a).

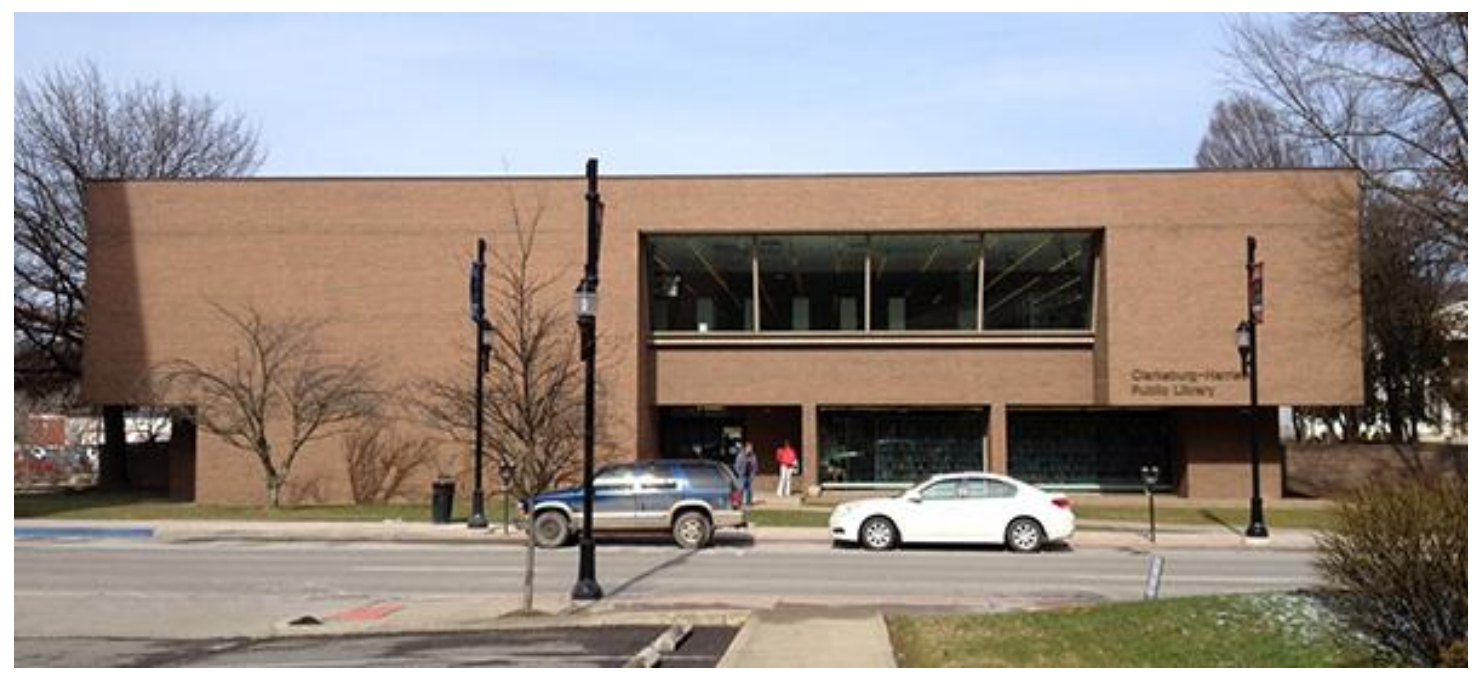

Figure 45: Clarksburg-Harrison Public Library front main entrance

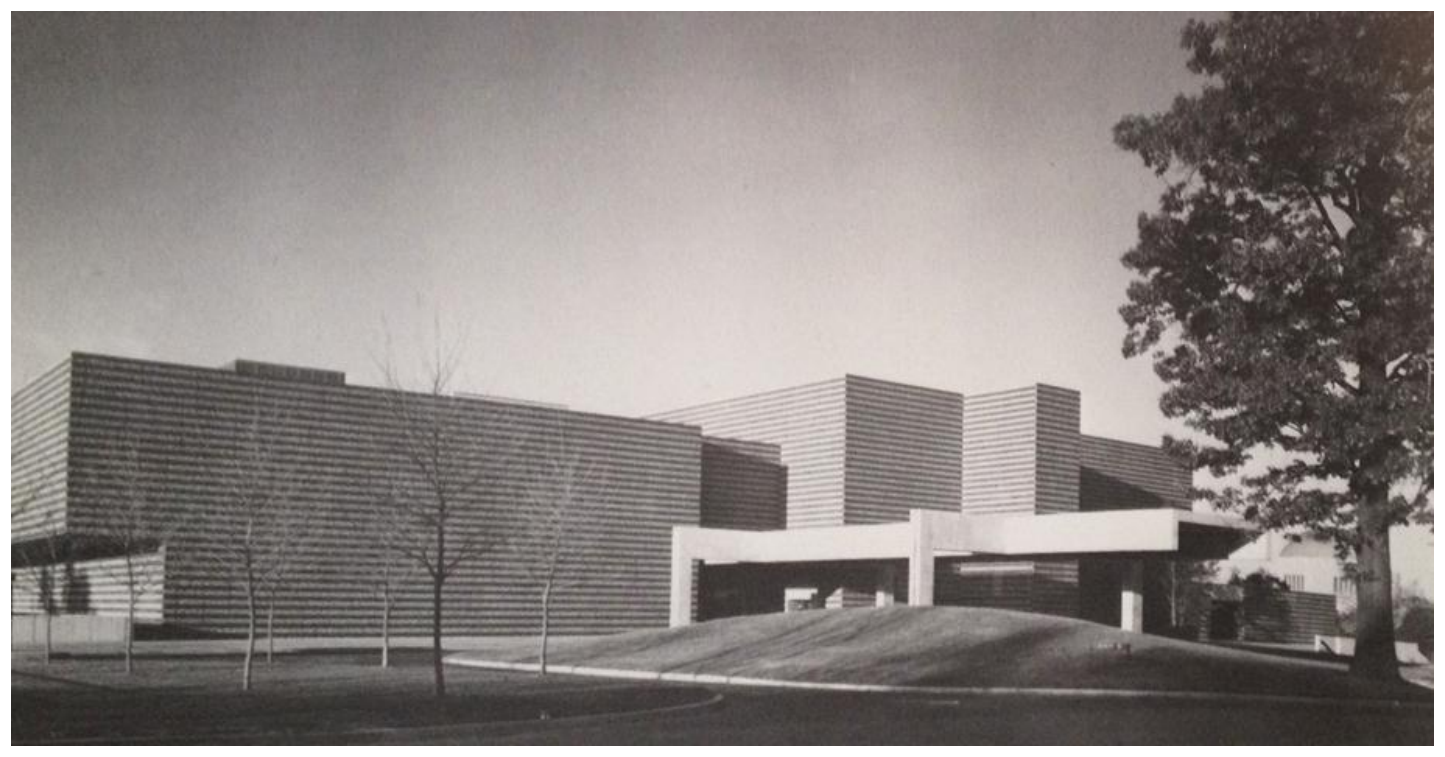

Figure 46a: The Cleveland Museum of Art Education Wing Expansion with canopy 
The Clarksburg-Harrison Public Library has no canopy that would emphasize the main entrance door, as is usual in Breuer's large-scale designs (See figure 45). That is why the Clarksburg-Harrison Public Library's entrance is more similar to Breuer's family house entrances than to an entrance for public purposes. The Cleveland Museum of Art, Education Wing's canopy also functions as a porte-cochere (See figure 46a). Cars, taxies and busses can drive in all the way to the main entrance door so that the public can have the most comfortable and protected entrance to the library. The Cleveland Museum of Art, Education Wing's oversized canopy functions as the element that gives a lively appearance to the building. The large-scale concrete structure looks like an insect with a vibrant colored body, without eyes and large long thin legs, moving quickly around the place. This gives the illusion of movement and speed to the visually heavy, robust and blocky body of the building. This canopy, however, further emphasizes the defensive appearance of the enigmatic structure of the building.
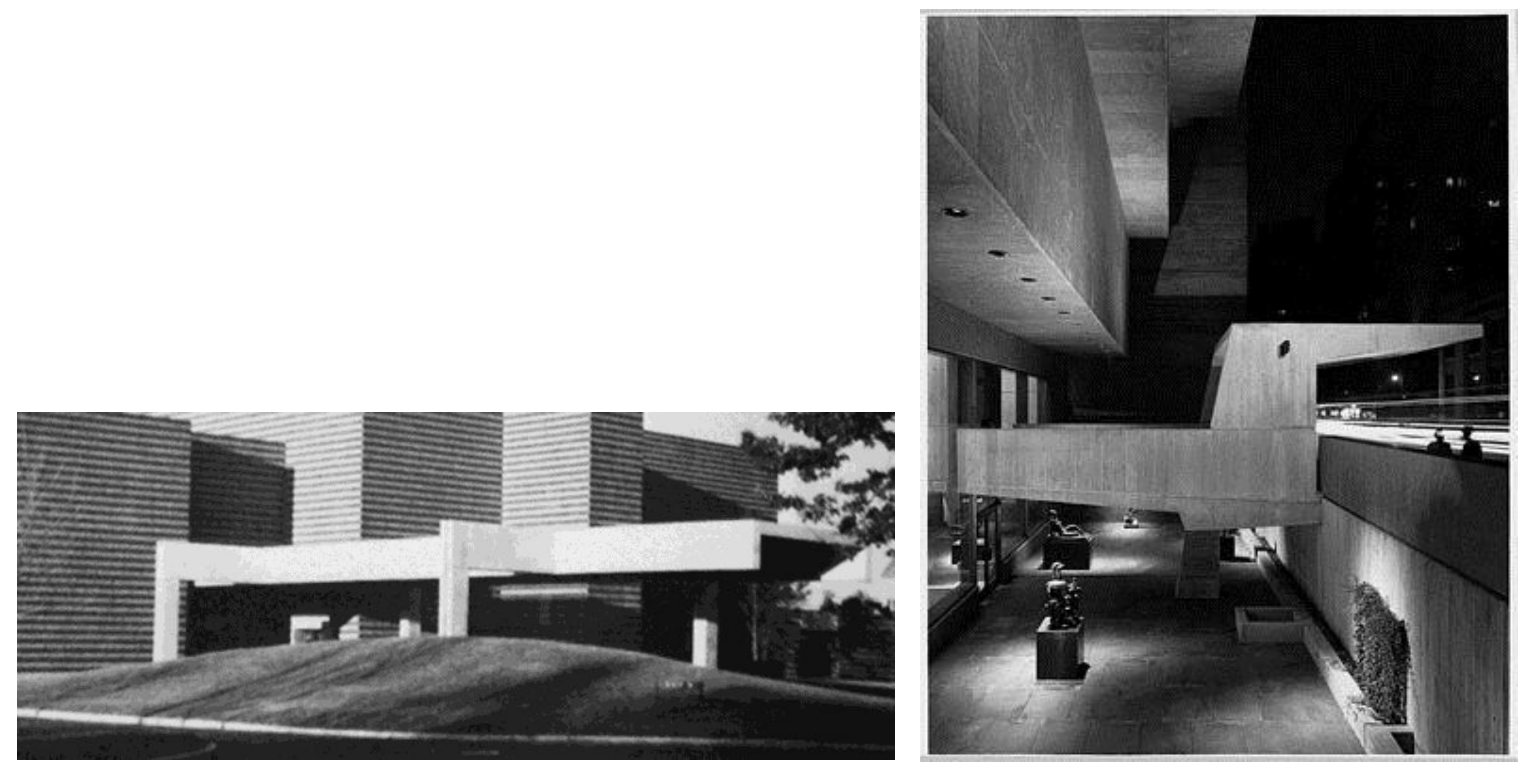

Figure 46b and 47: Cleveland Museum of Art, Ohio. Education Wing Northern Entrance, canopy (figure 46) and the Whitney Museum's canopy (figure 47). 
Breuer designed canopies from concrete for the majority of his large-scale buildings (See figure 48, 49 and 50). For Breuer the canopy had several purposes: to emphasize the entrance, to provide a clear view of the main entrance from a distance, to give shelter and protection and to further monumentalize the building.
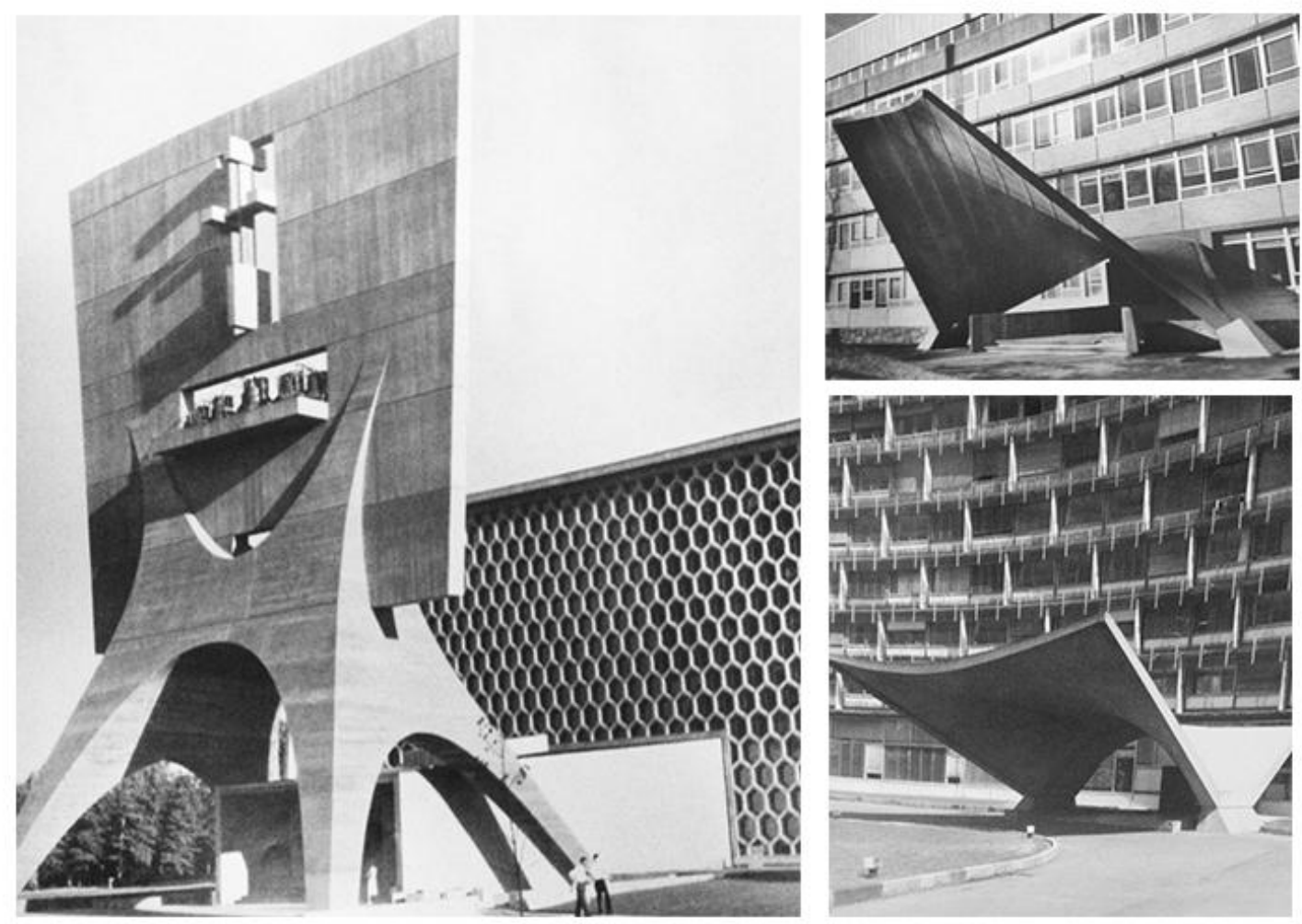

Figure 48, 49, and 50: Other canopies of Breuer that emphasizes the entrance of the building. Left: Saint John's University Library, Collegeville, Minnesota (1964-66). Right top: New York University, University Heights Campus, Bronx, New York (1959-70) Right bottom: UNESCO Headquarters, Paris, (1955-58).

The lobby of the Cleveland Art Museum resembles the interior design of the Whitney Museum (See figure 51 and 52) as well; the two lobbies are very similar (the sitting areas are almost identical), mainly due to their very similar functions. They have the same sitting areas, and have similar lighting from above. The lamps in the Whitney Museum, however, are circular, while in the Cleveland Art Museum they are placed in a square inlayed in coffers. 

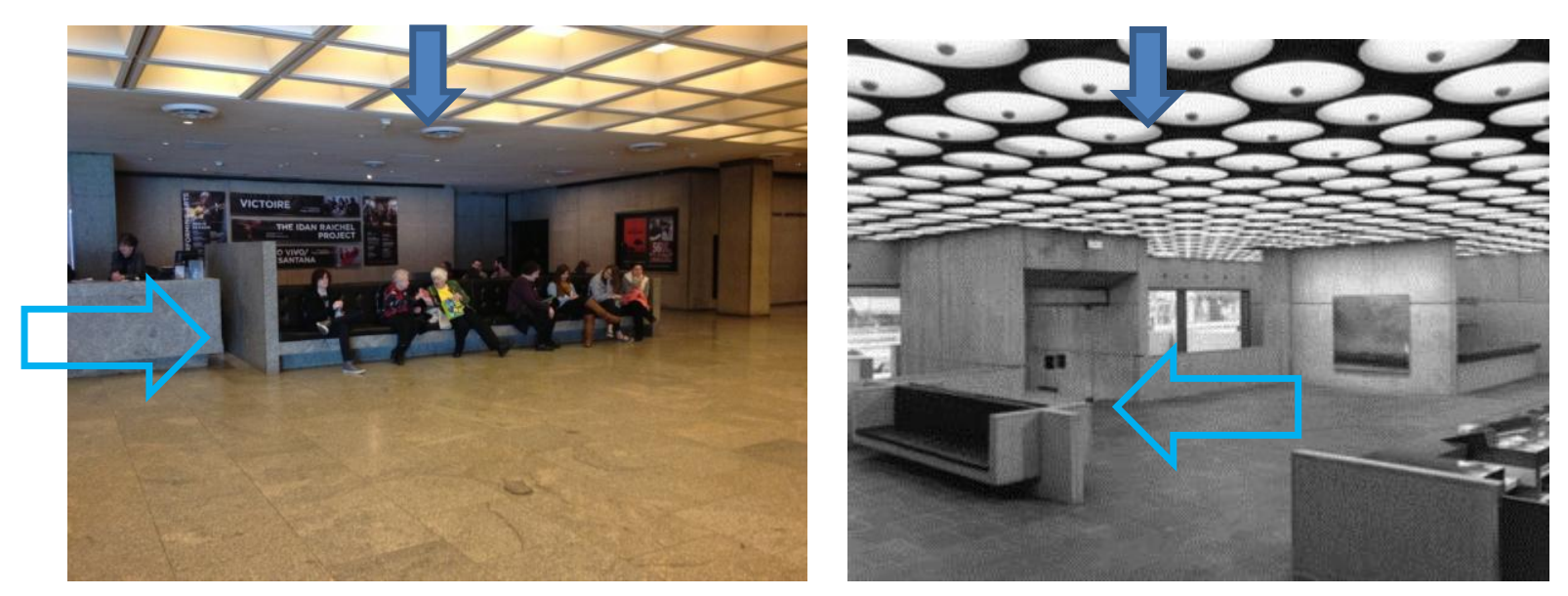

Figure 51: Lobby Cleveland Museum of Art, Education Wing,. Figure 52: Lobby of the Whitney Museum of American Art, NY, 1966.

Breuer's large-scale architecture was monumental and robust, however, in the case of the Clarksburg- Harrison Public Library; Breuer adopted a markedly different approach. When designing the library Breuer incorporated elements of his residential architecture, thereby softening the appearance of the library and making it house-like. In the next chapter I will continue to examine the residential quality of the ClarksburgHarrison Public Library. In particular, I will shed light on Breuer's ability to create an intimate public library by creating a platform, where the formal elements of his singlefamily house designs coexisted with the functional elements of a public library. 


\section{CHAPTER FOUR}

\section{Breuer's Medium-Scale Works: Breuer's Domestic Architecture}
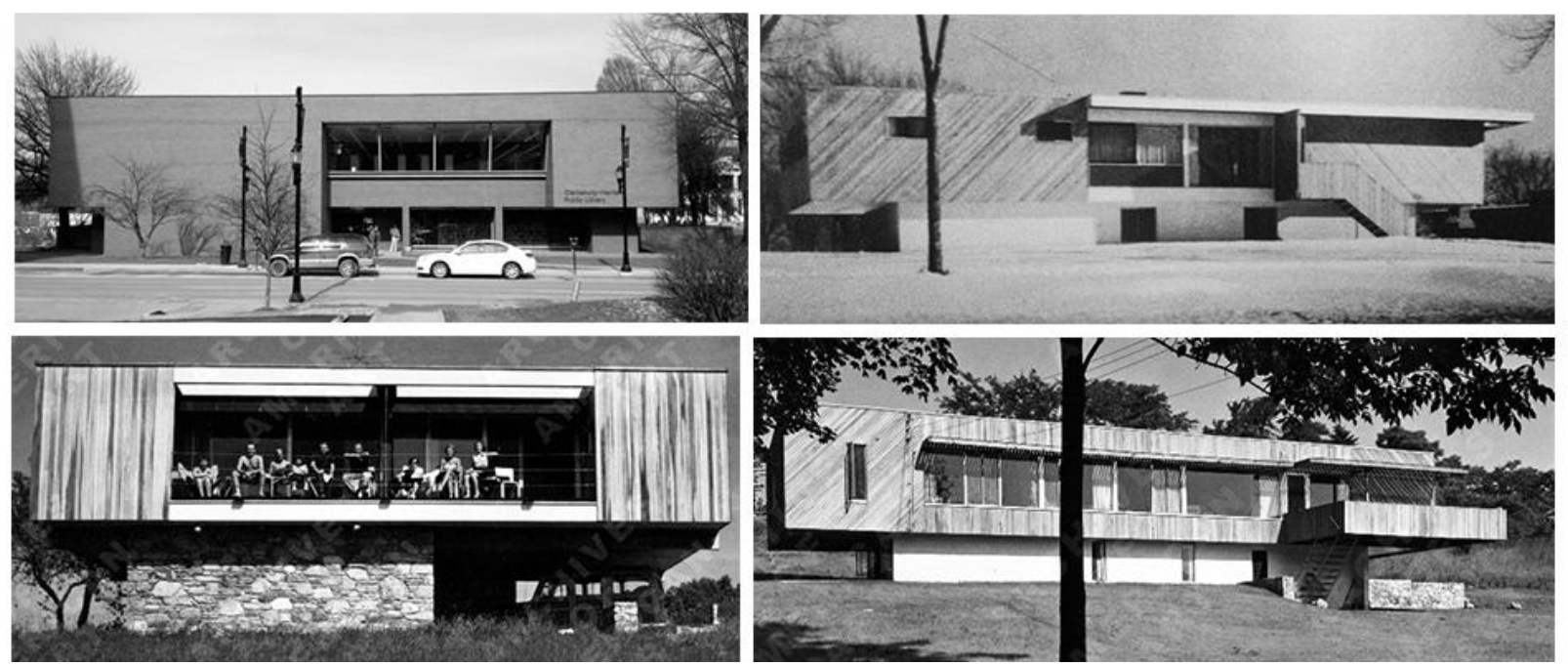

Figure 53, 54, 55, 56: Left top: Clarksburg-Harrison Public Library. Left bottom: Wolfson House. Right top: Snower House, Right bottom: Breuer House- New Canaan I.

The Clarksburg-Harrison Public Library, not only has similarities with Breuer's other large-scale public buildings, but it also share similar elements with some of his medium scale, residential/single family house designs. Although Breuer designed single-family house until the end of his career, his domestic/house architecture changed drastically in his large-scale period, and became more monumental and luxurious. Art historian Joachim Driller writes about how Breuer's residential architecture in many aspects changed after Breuer started to design larger scale works after the 1950s, and became more monumental and robust than before. In Driller's book Breuer Houses, he describes the late work as follows:

In retrospect, it is difficult to ignore the thought that these magnificent houses, especially with the works of art they contained, were already becoming monuments to modernism with a museum-like character. Created just before 
Breuer's monumental "concrete-sculpture", large-scale projects, they were already themselves beginning to crystalize into monuments to their creator. ${ }^{108}$

His late-period house designs were; the Koerfer House, Moscia-Tessin, Switzerland (1967), the Stillman House III., Litchfield, Connecticut, 1973, and the Bratti House, New Canaan, Connecticut (1979). Interestingly the Clarksburg-Harrison Public Library, even though it was designed in 1973, brings to mind Breuer's earlier, middle-scale period house designs. As the Clarksburg- Harrison Public Library resembles Breuer's earlier house architecture, I chose to analyze in this chapter Breuer's houses from the late 1940s and 1950s. The list of houses designed by Breuer, in this period, which have similar appearances to the Clarksburg-Harrison Public Library design is long. Just to mention a few: Breuer House- New Canaan I, New Canaan, CT (1947-48) (See figure 56), the Wolfson (Trailer) House Pleasant Valley, NY (1950) (See figure 54), and the Snower House, Kansas City, Missouri (1953-54) (See figure 55).This chapter focuses on two of Breuer's houses, the Breuer House- New Canaan I, New Canaan, Connecticut (1947-48) (See figure 56), and the Wolfson (Trailer) House Pleasant Valley, NY (1950)(See figure 54), in order to support my point and to underscore the similarity of these houses to the Clarksburg-Harrison Public Library. The reason I chose the Breuer House- New Canaan I, New Canaan, Connecticut (1947-48) (See figure 56), is the fact that this house was Breuer's own family house, and out of all of his houses this house and Wolfson (Trailer) House Pleasant Valley, NY (1950) (See figure 54) visually resemble the Clarksburg-Harrison Public Library most closely.

\footnotetext{
${ }^{108}$ Joachim Driller, Breuer Houses (London: Phaidon, 2000), 20.
} 
My hypothesis is that Breuer wanted to create a "home" like atmosphere for the citizens of Clarksburg. The Clarksburg-Harrison Public Library is unique among Breuer's work as never in his career did he use so much of his domestic vocabulary to emphasize a public building's "home like" features as in this library. In his Notes on Architecture in 1959 Breuer said: “... we may state that an apartment building will look quite different from a business building, theatre different from a town hall, a church quite different from a department store, house on the north side of the street different from one on the south side." ${ }^{109}$ The question arises: Why did Breuer still make the Clarksburg-Harrison Public Library so notably resemble his family houses designs, if not to emphasize the building's function as a "community home"?

This chapter focuses on comparing and contrasting the Clarksburg-Harrison Public Library with two of Breuer's residential house designs, the first his own private residence; the Breuer House- New Canaan I, New Canaan, Connecticut (1947-48), and the second: Wolfson (Trailer) House Pleasant Valley, NY, (1950). These similarities show that not only did Breuer create an appearance similar to a single family house, but also that he made the library most similar to his own home. By doing so I would like to prove that Breuer expresses the use of his domestic vocabulary on the Clarksburg-Harrison Public Library in order to provide the library's additional function, to operate as a public home for the community of Clarksburg. My hypothesis is that the Clarksburg-Harrison Public Library of Breuer is more of an enlarged family house than a civic structure. Breuer uses the domestic vocabulary to emphasize the building concept as a "community home".

\footnotetext{
${ }^{109}$ Smithsonian Online Archive, Marcel Breuer Collection, Speeches and Lectures by Breuer: Manuscript and typescript of lecture: "Notes on Architecture," 1959 (Box 7, Reels 5718 Frame 1003-1010), http://www.aaa.si.edu/collections/container/viewer/Manuscript-and-typescript-of-lecture-Notes-on-Architecture-179437.
} 
Breuer in his house architecture was known for his flat roof, large glass wall juxtaposing massive walls, emphasizing the texture of different materials such as slabs of wood and natural stone, experimental and mostly dealing with standardization and mass-production. However, contrary to many modern architects, it is important to stress that Breuer always thought of architecture as a spiritual task besides solving technical and functional problems. Breuer said: "...functional needs are not only physical, but also human and spiritual. The house is not a 'machine for living'..."110 In contrast to his house architecture, his large-scale designs were robust, enigmatic, heavy, monumental and sculptural designs and were the beginning of the 'brutalist architecture'. Marcel Breuer's house designs are strikingly different from his largescale designs.

Breuer's house architecture became a huge success in the United States in the early 1940s, and his successes only grew with time. ${ }^{111}$ This was due to Breuer's ability to merge standardization and individuality in the same platform. Breuer also experimented with different materials, and the newest techniques in his house designs. "Experiment is one of the responsibilities of the architect, and I have found that most clients are willing to share the venture, the calculated risk." 112 This fresh and experimental approach was the unique characteristic of Breuer's house designs. Driller in his book Breuer Houses writes about Breuer's arhitecture:

\footnotetext{
${ }^{110}$ Smithsonian Online Archive, Marcel Breuer Collection, Speeches and Lectures by Breuer: Typescript of speech for panel discussion: "Individual Expression Versus Order," Toronto, 1974 (Box 7, Reels 5718 Frame 1269-1289), http://www.aaa.si.edu/collections/container/viewer/Typescript-of-speech-for-panel-discussion-IndividualExpression-Versus-Order-Toronto--179453.

${ }^{111}$ In 1948 the Museum of Modern Art, NY commissioned Breuer an exhibition house to display in the Museum Garden, from which MOMA put together a travelling exhibition and published a monograph on Breuer's work. This travelling exhibition made Breuer's name known to the large public.

${ }_{112}$ Peter Blake, Marcel Breuer: Sun and Shadow, The Philosophy of an Architect, ( New York: Dood, Mead \&Company, 1956), 11.
} 
Breuer's motifs of the self-contained box and the distinct additive principle, which he developed during the 1920s and first applied in the first Harnischmacher House, became a characteristic feature of his architecture in both his English houses, particularly Sea Lane House, and his American houses, in which his obsession with the American 'balloon frame' method acquired special significance. ${ }^{113}$

Breuer was "setting the style of the post- Second World War residential architecture" 114 in the United States as Joachim Driller wrote in his book Breuer Houses. However, his success and good reputation as a house architect only brought him larger commissions in the mid-1950s. Breuer was eventually able to break through the medium scale house architecture and come to be known today for his monumental large-scale designs.

After the late-1950s Breuer created only seven private residential houses, in these few houses, Breuer's house architecture became much more luxurious and larger than before. "Breuer talked about his house designs to Time Magazine in an interview in 1968: "I only do a few - just for the fun of it."115 The main questions Breuer asked himself when designing his houses was: "how does it conform to my life as an individual, to my life with my children, to my needs for privacy, for security, to my pocket-book, to my long-term wish for a friendly aesthetic?" 116

Breuer had two main house-plan types; the "long plan" (See figure 58) which can be one or two story houses and the "bi-nuclear plan", which can be either H-shaped or U-shaped. The advantage of the "bi-nuclear plan" is that it separates even further the children's areas from the

\footnotetext{
113 Joachim Driller, Breuer Houses (London: Phaidon, 2000), 31.

114 Joachim Driller, Breuer Houses, ( London: Phaidon, 2000), 8.

${ }^{115}$ Isabelle Hyman, Marcel Breuer, Architect, the Career and The Buildings, (New York: Harry N. Abrahams, INC., publisher2001), 161.

${ }^{116}$ Peter Blake, Marcel Breuer: Sun and Shadow, the Philosophy of an Architect, (New York: Dood, Mead \&Company, 1956), 32.
} 
more public areas of the house; therefore, it gives even more privacy than the "long plan" house design. The long plan house design, however, also separates the living areas (living room, kitchen, dining room) from the more "private" spaces (bedrooms, study room, bathrooms). In both plans Breuer separates the sleeping areas from the living spaces by the hallway, creating a bipolar house. For Breuer the two opposites had to coexist next to each other, the private and the public space separated but under the same roof. He opined: "So there are two obvious and completely opposite requirements in planning a shell for the family: one is that the parents want to live with the children, have their fun with them, help them grow up; and the other is that both the children and the parents must be able to have their own lives."117

Breuer also created the Hillside Houses, where the hill elevation opens up the lower level access to the outside and allows the upper level to function as the main floor. Usually Breuer has two main solutions for house design, the house either sits on the ground from where one can easily walk out to the outside, and the other solution is the house that sits on pilotis, elevated from the grounds. The advantage of the house on pilotis is that one can enjoy the view of the landscape better. However, when a house is built on the hillside the effect is dual. One can have the elevated view and have direct exits to the landscape.

On the top floor, looking downhill, you find yourself standing on a platform, up in the air, floating above the landscape. We would then put the children's playroom on the lower floor, so that they could walk out into the grass and play outdoors any time they feel like it. Down there you have the feeling that the house hugs the ground- and it does. ${ }^{118}$

Most of Breuer's hillside houses have a very significant top-heavy appearance. Breuer created an optical piano nobile, which can be noticed when observing these houses from the

\footnotetext{
${ }^{117}$ Peter Blake, Marcel Breuer: Sun and Shadow, the Philosophy of an Architect, (New York: Dood, Mead \&Company, 1956), 35.

118 Joachim Driller, Breuer Houses, (London: Phaidon, 2000), 175.
} 
outside. Breuer created this optical illusion of top-heavy houses, by placing the first floor half under the earth, increasing the optical height differences between the two.

Breuer as a member of the Harvard Five architecture group created several houses in the quiet upscale town of New Canaan, Connecticut. New Canaan is a special place for modern architecture, as the Harvard Five architects not only designed houses for their clients there, but they also chose to build houses for themselves. Besides Breuer all of the Harvard Five architects built their private resident houses here, including Eliot Noyes, Landis Gores, Philip Johnson, and John Johansen.

\section{Case Study 3: Breuer House- New Canaan I, New Canaan, Connecticut, 1947-48}

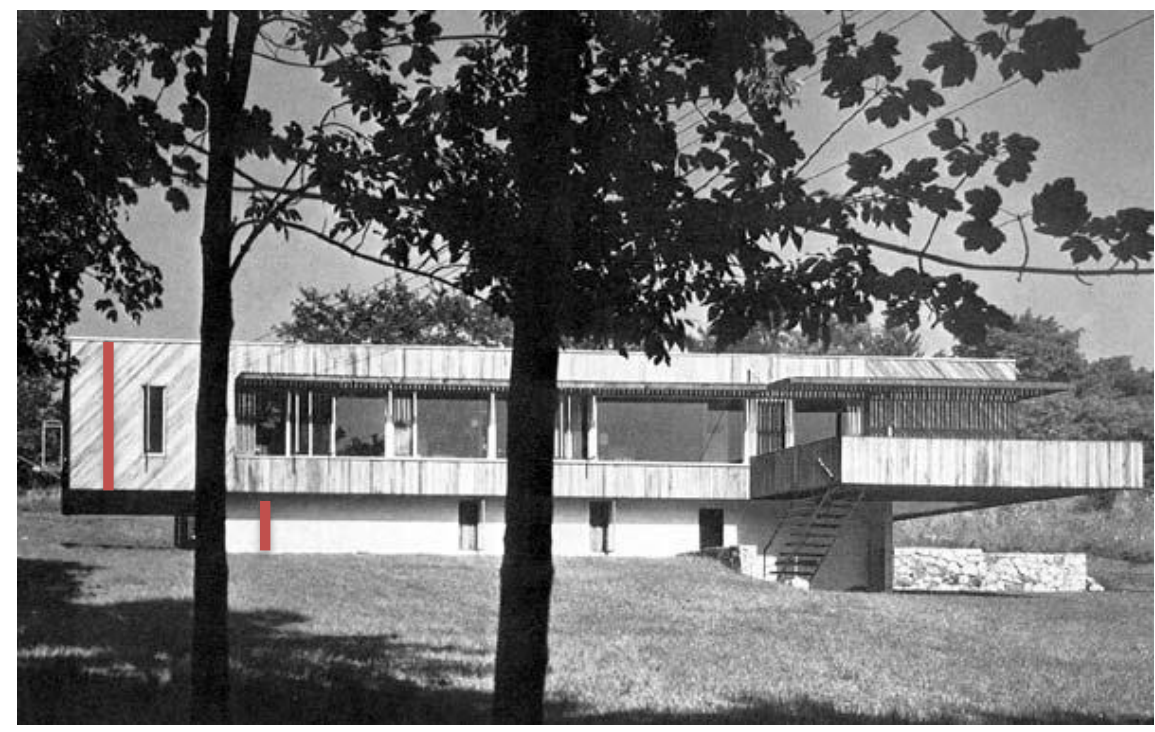

Figure 57: the original Breuer House- New Canaan I, New Canaan, CT, 1947-48 
Breuer built the Breuer House New Canaan I (See figure 57), as a compact house and as a full-time private residence for himself and his family in New Canaan, Connecticut in 1947-48. ${ }^{119}$ In the suburbs of New York City in a well-off and family friendly neighborhood, Breuer bought the plot and started working on his new design, which had a "long house" plan design (See picture 58). The Breuer House I, New Canaan is a two-story private residential design. As there were no clients involved Breuer had a free hand of experimentation. Besides Breuer's aim to build a home for himself and his family, he used it as a laboratory for realizing his architectural philosophy and experimenting with the newest technical innovations.

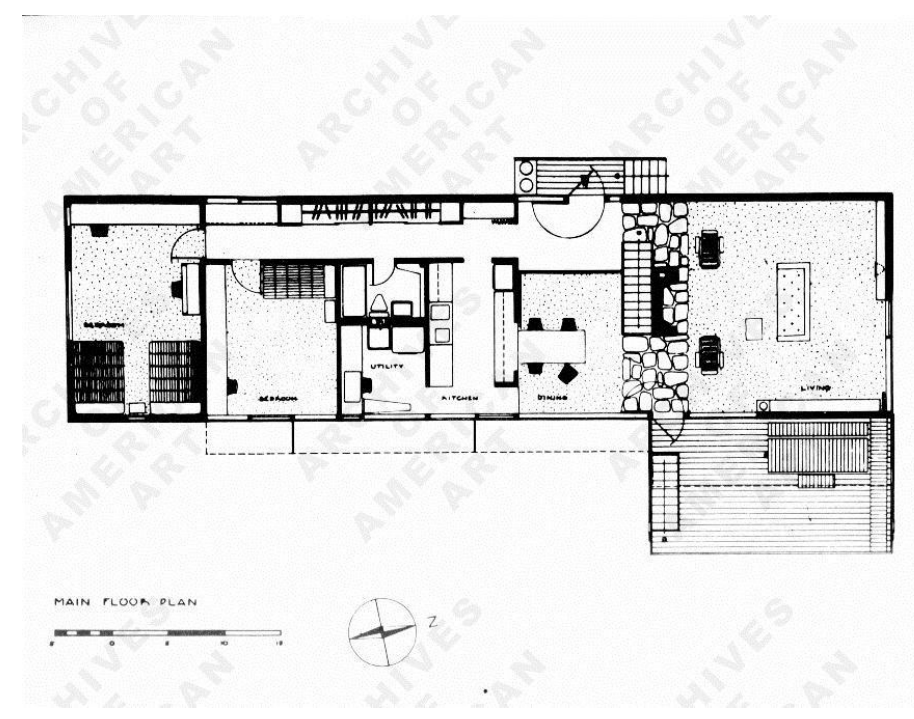

Figure 58: Long house plan of Breuer House- New Canaan I, New Canaan, CT, 1947-48.

As the lot is located on a slope the house is considered to be a "hillside house", the entrance is from the upper level and the lower level opens up to the outdoors. The main entrance is located on the second floor, and from the front the house looks as if it was only one-story high. The upper-level of the Breuer House is separated by the hallway into "sleeping areas" on the left

\footnotetext{
${ }^{119}$ Breuer built all together four houses for himself through his career, and this was his second house.
} 
and the living areas on the right where friends and family can get together (See figure 61). Breuer put the children's room in the lower-level. Separating the individual from community, and the living areas from sleeping areas, were all part of the "Sol y Sombra" philosophy of Breuer, the coexisting opposite poles. The Breuer House New Canaan I also has a projecting porch (See figure 59). Similar to Frank Lloyd Write's Fallingwater rural house in Pennsylvania, 1935, which cantilevers over a water fall. It is not surprising that Breuer, just like other architects of his time, was pushing the limits of engineering. The large suspended cantilevered overhanging balcony created many technical problems for Breuer and delayed its construction. Breuer, however, knowing the risks and expenses of the projecting porch went along with the plan and considered it an experiment. The end result of the large cantilevered overhanging balcony experiment was an unresolved structural problem of the house that had run over the estimated budget. ${ }^{120}$ Breuer learned a lot from this experience and used overhanging cantilevered upper levels in his large-scale, non-domestic designs as well at the Whitney Museum and at the Clarksburg- Harrison Public Library.

\footnotetext{
${ }^{120}$ At the end Breuer had to put a wall support underneath the cantilevered porch in 1948. Breuer later sold this house to the Robeck family, who made further restorations and alterations to the house.
} 


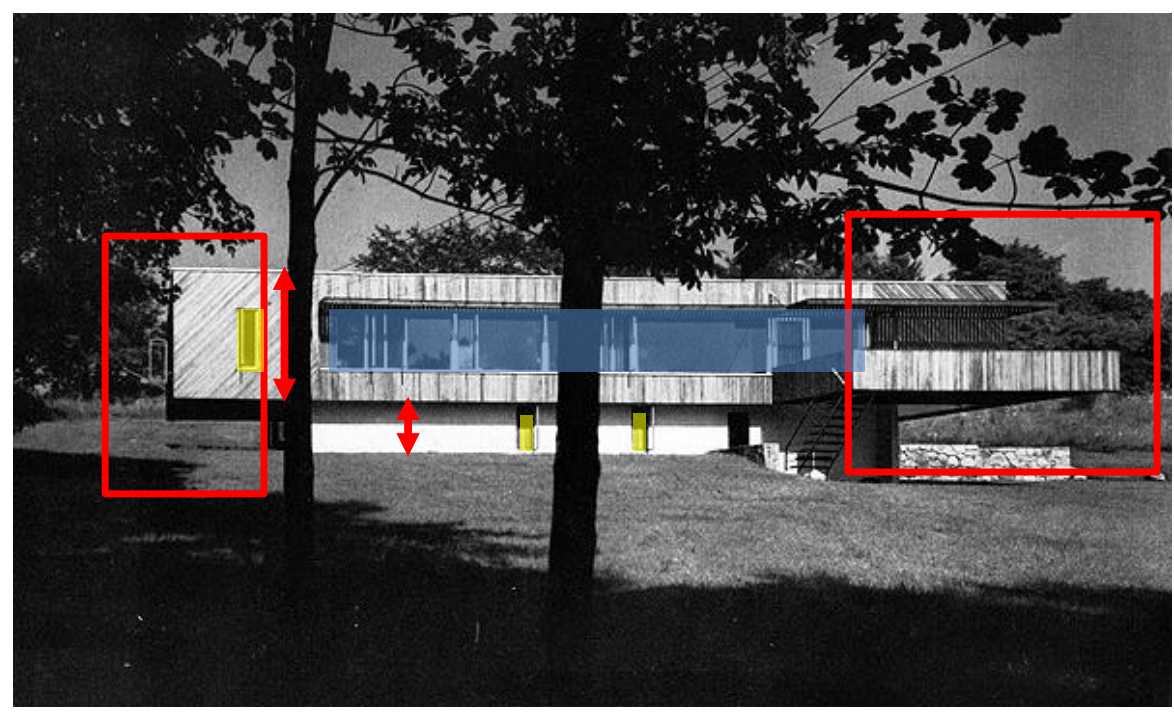

Figure 59: Cantilevers at the Breuer House- New Canaan I, New Canaan, CT, 1947-48

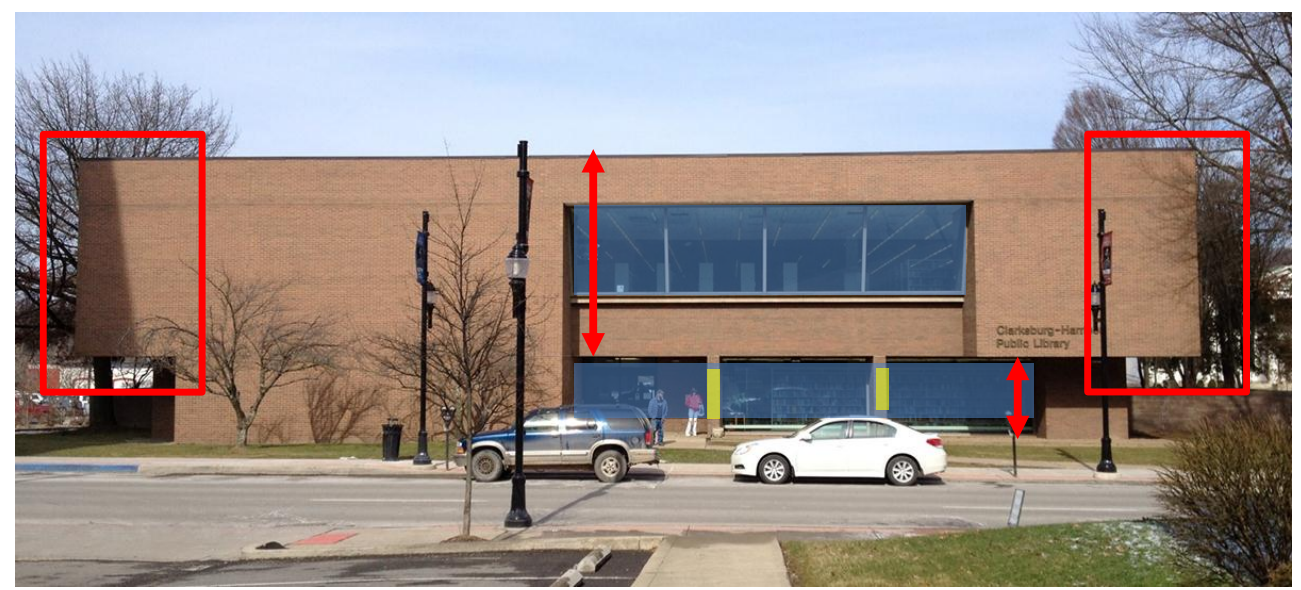

Figure 60: Cantilevers at the Clarksburg-Harrison Library, WV, 1975

The spread of horizontal windows of the two designs also resemble one another. The narrow, vertical openings on the lower level of the Breuer House bring to mind the pilotis of the Library. Above the windows and porch Breuer designed lattice sun shade screens. They not only protect from the sun, but the shadows create lines as a decorative element on the house. 
The furnishing were all designed by Breuer, which created a formal unity. Breuer applied the Gesamtkunstwerk of the Bauhaus principals in most of his houses. The furniture that Breuer used in his personal house was low cost furniture, standardized, mass-produced designs, for example, the Cesca chairs, which were also used at the Clarksburg-Harrison Public Library design.

When studing the floorplans of Breuer's "long plan" houses, there are many similar elements to the floor plan of the Clarksburg-Harrison Public Library. One of the stricking similarities is the separation of living area from the sleeping areas, and the separation of the "community/family" vs. " individual”. One can observe in the Breuer House- New Canaan I, that the fireplace is attached to the staircase that connects the lower and upper level. The fireplace, like the staircase, function as a metaphore for the "heart" or the center of the house, similarly to the designs of Frank Lyord Right. Breuer applies this element of his house architecture in the design of the Clarksburg- Harrison Public Library as well (See figures 61, 62 and 63). 

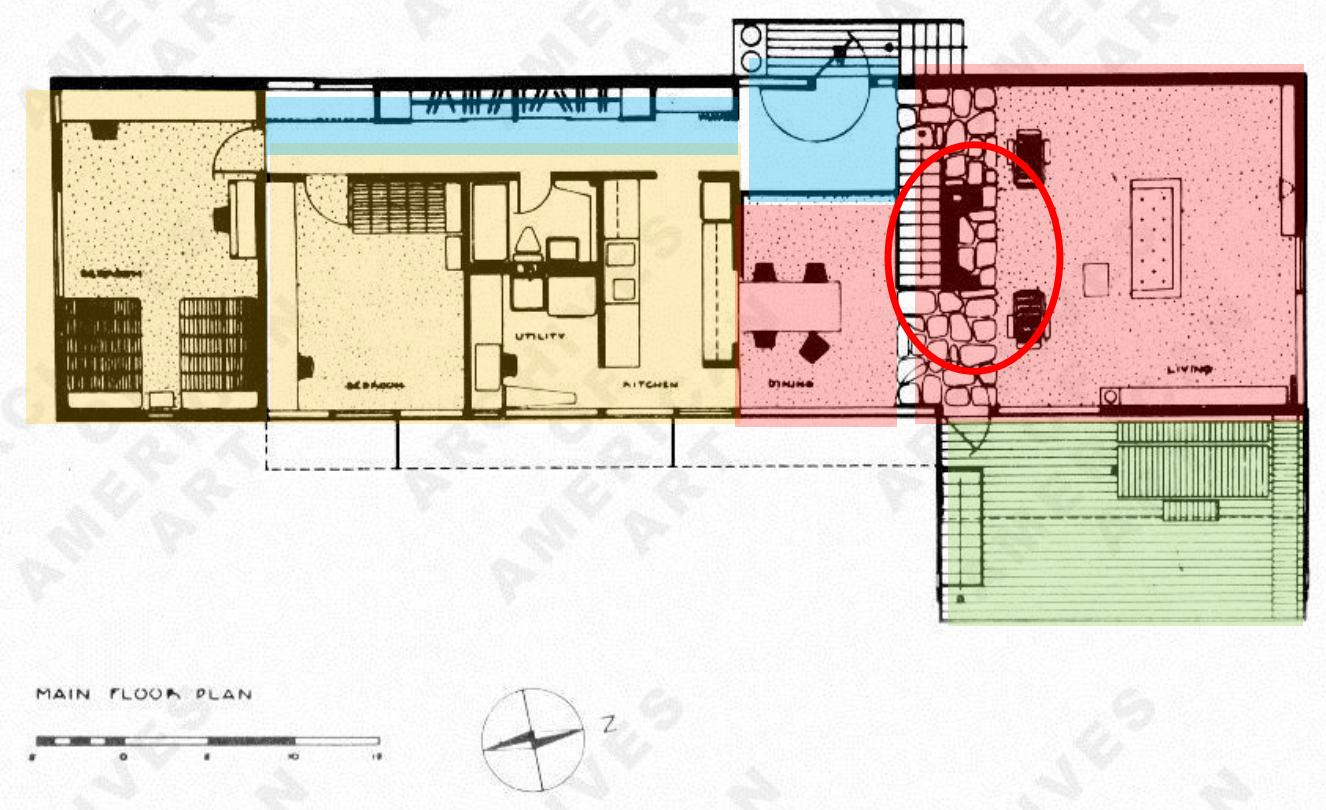

Figure 61: Breuer House- New Canaan I, New Canaan, CT, 1947-48. Main Floor Plan: entrance/ corridor, living area, sleeping area, courtyard, fireplace and staircase 


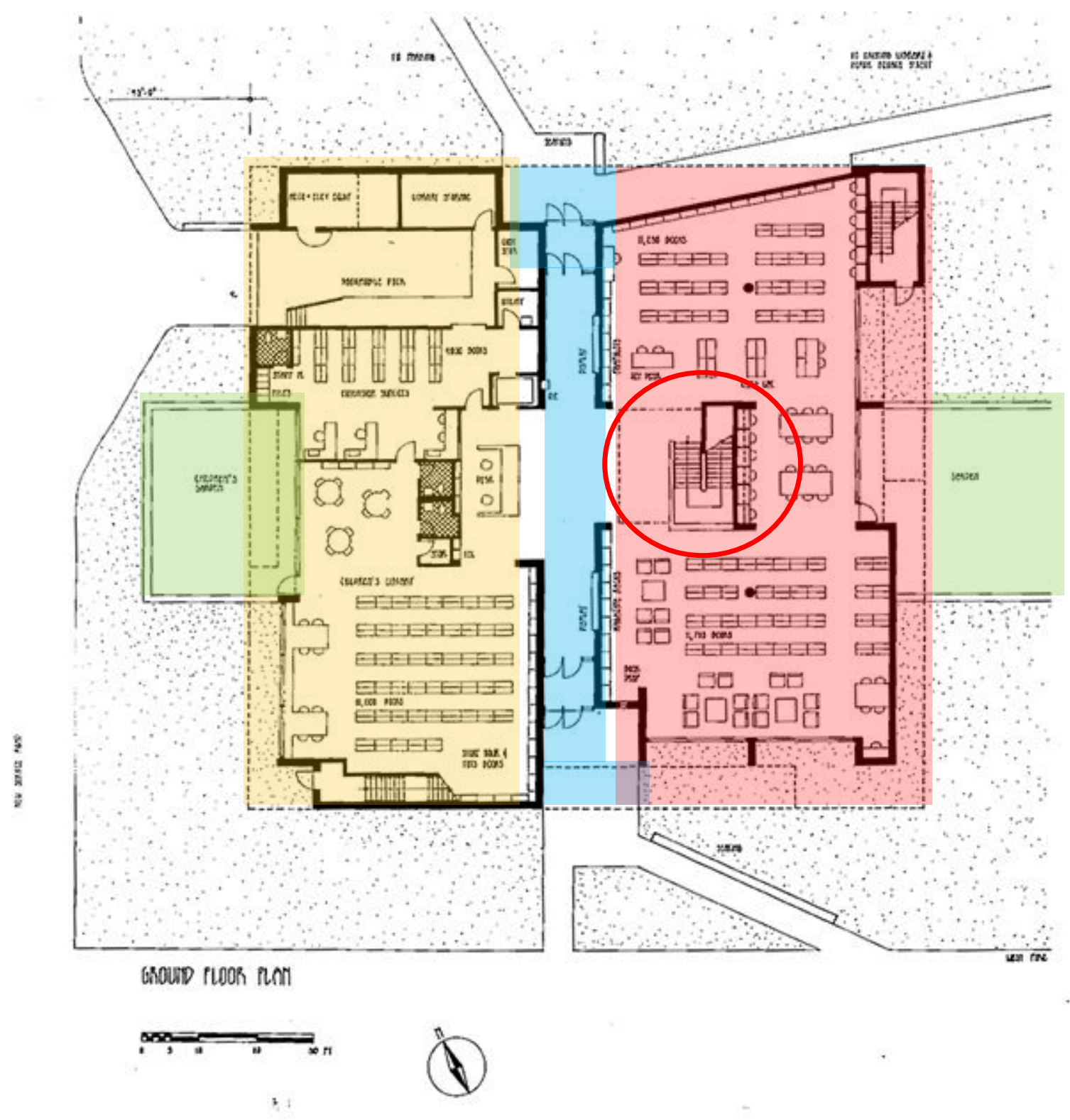

Figure 62: Clarksburg- Harrison Public Library, Main Floor Plan: entrance/corridor, living/public/community area, sleeping/children/private area, courtyard, staircase 


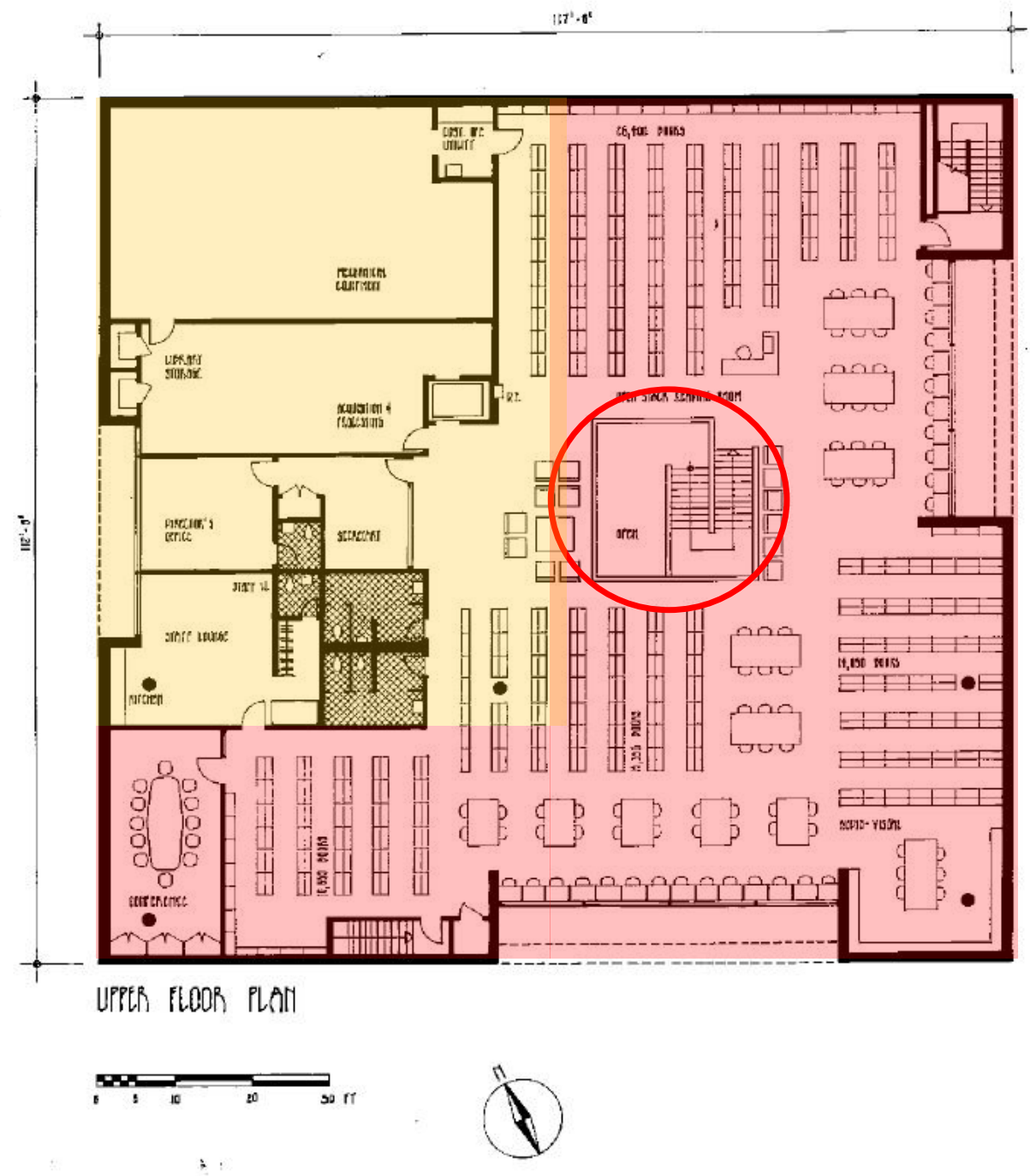

Figure 63: Clarksburg- Harrison Public Library, Upper level, floor plan: living/public/community area, sleeping/children/private area, staircase

When observing the floor plan of the Clarksburg-Harrison Private Library, one can tell there is a separation of "community" and "individual". Also, the children's reading room is on the lower-level, and has direct access to the outside reading room, just like in Breuer's own house design. This separation of community/family vs. individual can be observed in the third house Breuer built for himself and his family in New Canaan, Connecticut in 1951(See figure 
64). At the Breuer's House in New Canaan, one can see the same pattern of organization. It is interesting to note that the Clarksburg-Harrison Public Library is most similar to Breuer's own house designs, and the number of similarities is not typical in his other house designs.

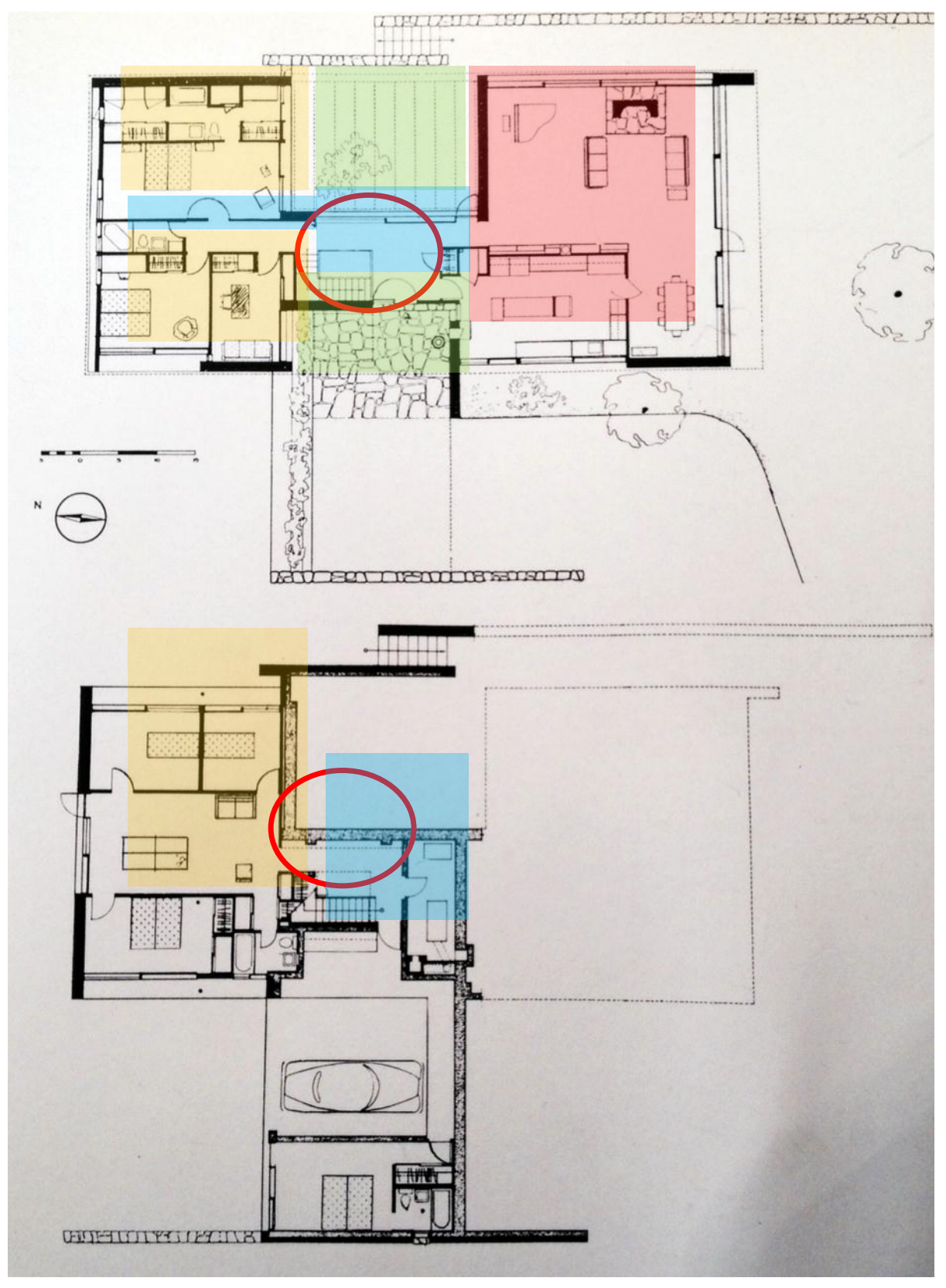

Figure 64: Breuer House, New Canaan II., New Canaan, CT, 1951. First and second floor, floor plan: entrance/corridor, living/public/community area, sleeping/children/private area, courtyard, staircase 


\section{Case Study 4: Wolfson (Trailer) House Pleasant Valley, NY, 1949-50}

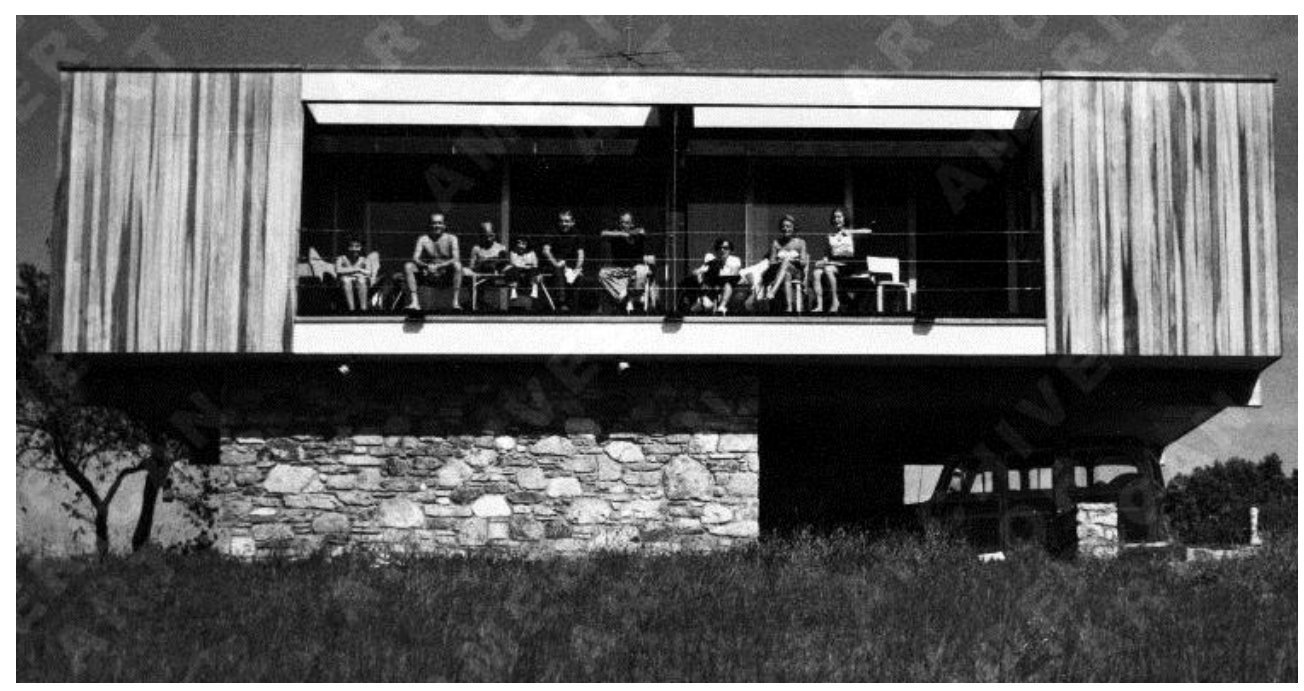

Figure 65: Wolfson (Trailer) House Pleasant Valley, NY, 1950.

The Wolfson (Trailer) House Pleasant Valley, NY (See figure 65), was built in 1950 for the owner who wanted to incorporate his trailer into the design of the house. The house is connected directly to the trailer. The kitchen and dining area are in the trailer, and the sleeping and living areas are in the house itself. This house is a perfect example of the top-heavy look of Breuer's own house design. Breuer created the optical top heaviness, by enlarging the area space on the upper level and by placing the second level of the house on cantelivered steel freams (See figure 66 ). Although the piano nobile is not applyed at the Wolfson House, the main living area is still on the upper level of the house. Just like at Le Corbusier's Villa Savoye, Breuer creates a lower level that is used for the driveway, car shelter and entrance hall with service room.

The shocking similarities between the façade of the Wolfson Trailer House and the Clarksburg-Harrison Public Library (See figure 66 and 67) was the reason I used this house as my next case study. If one looks at the two buildings from the outside, one immediately recognizes the similarities of the two lower levels. Breuer created the effect of tension and 
drama, by placing next to each other the solid wall and the transparent hollow spaces, refering back again, to his architectural phylosophy of "Sol y Sombra".

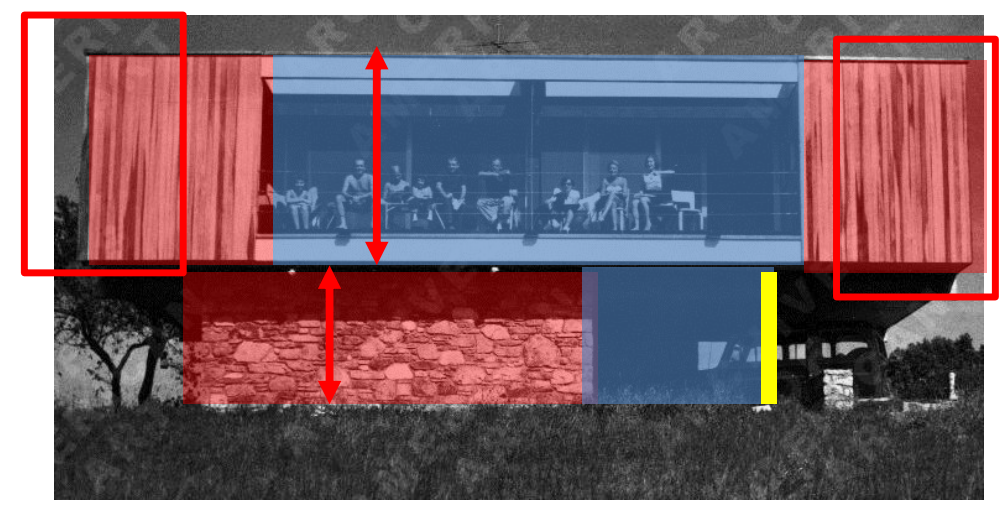

Figure 66: Top-heavy look of Wolfson (Trailer) House Pleasant Valley, NY, 1950

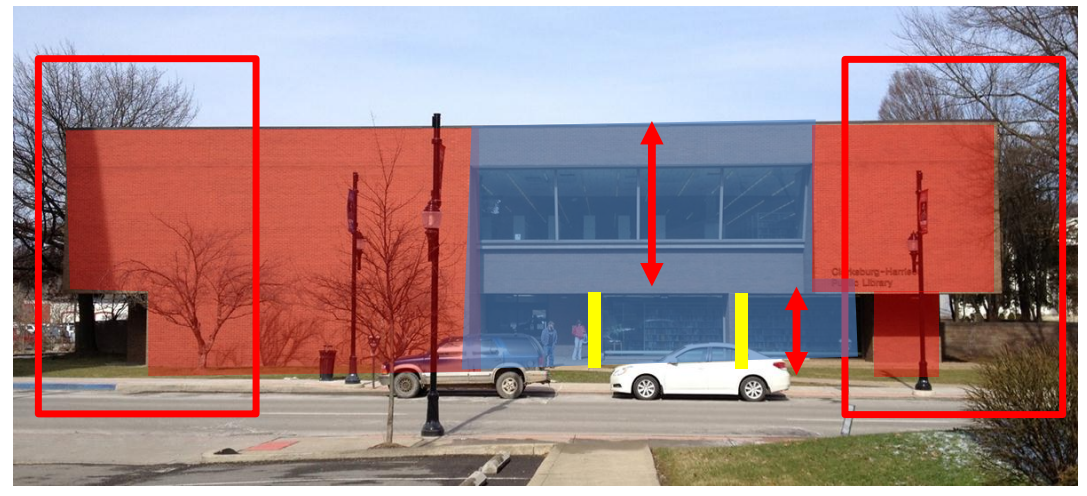

Figure 67: Façade of the Clarksburg-Harrison Library, 1975, WV. Compositional decisions of Breuer 

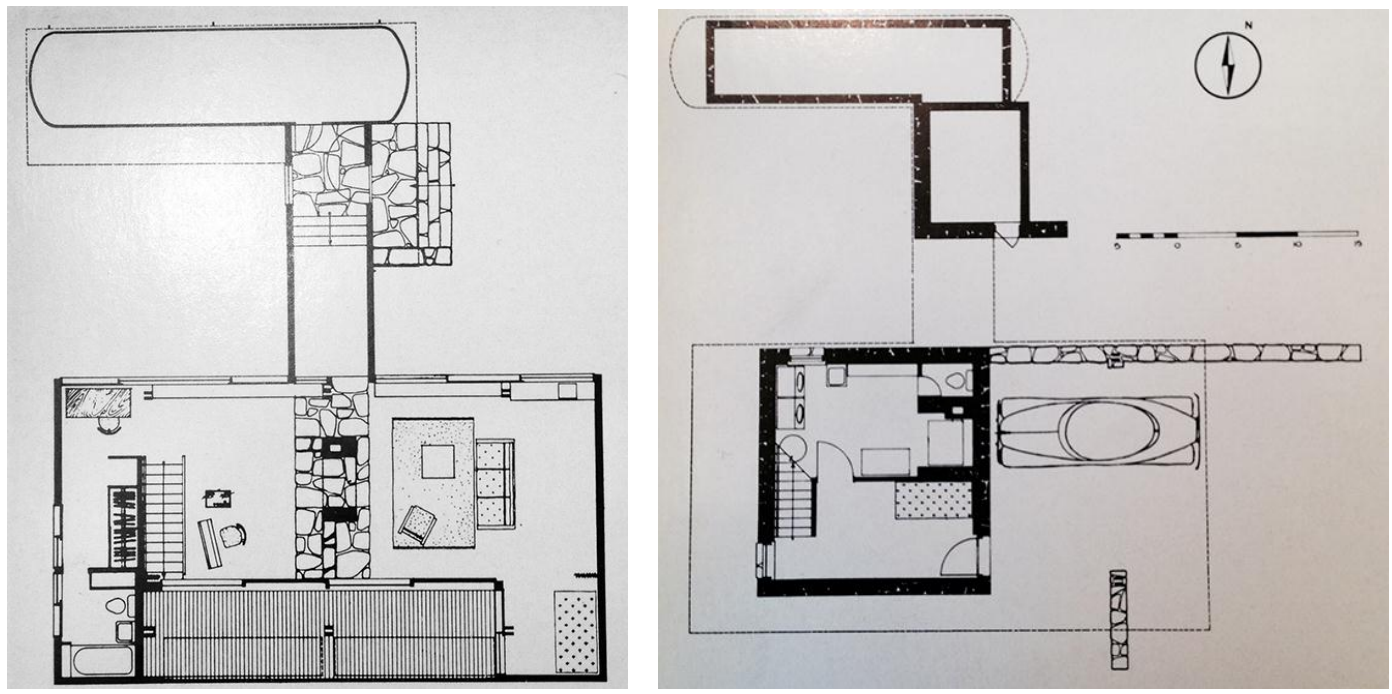

Figure 68 and Figure 69: Wolfson (Trailer) House, Floor Plan, Pleasant Valley, NY, 1950. 


\section{CONCLUSION}

Overall, we can conclude that the Clarksburg-Harrison Public Library is a true and sincere manifestation of Breuer's architectural philosophy of "Sol y Sombra". It is furthermore unique among Breuer's designs as it includes his house architectural elements, recalls his own private residential house designs and lets his medium-scale house design live together with his largescale design. It is interesting to observe this phenomenon, as Breuer's house designs became monumental during his last period. In the case of Clarksburg-Harrison Public Library we can see the opposite, where Breuer's large-scale design became house-like.

This phenomenon shows Breuer's everlasting devotion to the functional, and spiritual need of the project. The Clarksburg-Harrison Public Library is the most sincere symbol of the "public home" that Breuer ever created and therefore, it is unique among Breuer's work. As Breuer was asked to design a "home" for the children of Clarksburg, he remembered his own home and was influenced by the choices he made in his own house design. "Sol y Sombra" the architecture of contrast dominated his philosophy, where the solid wall coexists with transparence, where individuals coexist in harmony with the community/family, where outside coexists with the inside, but never blur together. The acceptance of the sun and the shadow, the ability to comingle the opposite poles on the same platform was Breuer's genius. The Clarksburg-Harrison Public Library is a true and sincere manifestation of Breuer's architectural philosophy.

With the Clarksburg-Harrison Public Library, Breuer achieved to express the needs of the board of the Clarksburg Public Library, to give the children of Clarksburg a community, where they could feel they belong. The public library of Clarksburg needs to be reconsidered in the 
light of the new context of community-oriented public building and needs to be recognized as a cultural and architectural landmark of Clarksburg, West Virginia. The Public Library of Clarksburg sets an example of the importance of cultural investments in order to develop a healthy community of individuals that choose to stay in their hometown.

By bringing in Marcel Breuer, an internationally well-known architect of his time, Clarksburg, West Virginia succeeded in giving its people a modern, public library, where they can cultivate their minds and spirits, and where they can bond together as a community. Breuer's public library is an example of great architectural masterpiece that combines house architectural appearance with the public library design, to create a building that benefits the individual and the community, an asset belonging to the city of Clarksburg. This thesis aims to contribute to the literature on the Clarksburg-Harrison Public Library and is an attempt to shed light on Breuer's little-known and only library in West Virginia. 


\section{BIBLIOGRAPHY}

Blaser, Werner. Mies Van der Rohe. New York: Praeger Publishers, 1972.

Breuer, Marcel. Marcel Breuer: An Exhibition Organized by the Metropolitan Museum of Art, New York: The Metropolitan Museum of Art, 1972.

Breuer, Marcel and Hamilton P. Smith. "The Cleveland Museum of Art Education Wing Expansion Site Plan.” from the Archives of American Art web site, http://www.aaa.si.edu/collections/container/viewer/Photographs-of-plans-drawings-andconstruction--179897\#, CMA1, accessed March 11, 2013.

Blake, Peter. Marcel Breuer: Sun and Shadow, the Philosophy of an Architect. New York: Dood, Mead \&Company, 1956.

Blake, Peter. Marcel Breuer, Architect and Designer, New York: The Museum of Modern Art, 1949.

“Cleveland Museum's Architectural Acquision: New Education Wing of the Cleveland Museum of Art by Marcel Breuer Forges a Strong Architectural Merger with Two Earlier Buildings.” Interiors 130, no. 8 (1971): 108-111.

Cobbers, Arnt. Breuer, Köln: Taschen, 2007.

Conrads, Ulrich. Programme und Manifeste zur Architektur des 20. Jahrhunderts, Berlin 1964.

Driller, Joachim. Breuer Houses, London: Phaidon Press Limited, 2000.

Earls, William D. The Harvard Five in New Canaan: Midcentury Modern Houses by Marcel Breuer, Landis Gores, John Johansen, Philip Johnson, Eliot Noyes, and Others, New York: W. W. Norton \& Company, 2006.

"Education and Gallery Wing, Cleveland Museum of Art, Cleveland, Ohio, 1970" Architecture 32; no. 2 (1982): 74-77.

Ernyey, Gyula. Breuer Marcell- Marcel Breuer Principles and Results, Pécs: Pro-Pannonia Kiadó, 2008.

Gatje, Robert F. Marcel Breuer - a memoir, New York, The Monacelli Press October 2, 2000.

Gropius, Walter. The New Architecture and the Bauhaus, Boston: Charles T. Branford Company, 1955. 
Hitchcock, Henry Russell, Philip Johnson. The International Style, New York: Norton, 1966

Hoffmann, Donald. Frank Lloyd Wright's Falling Water: The House and its History. New York: Dover Publications, Inc., 1978.

Hyman, Isabelle. Marcel Breuer, Architect, the Career and the Buildings, New York: Harry N. H.N. Abrams, 2001.

Ichinowatari, Katsuhiko. The Legacy of Marcel Breuer, Tokyo: Process Architecture, 1980.

Izzo Alberto and Camillo Gubitosi. Marcel Breuer, Architectura 1921-1980. Firenze: Centro Di.cat, 1981.

Jacob, Mary J. Chicago Makes Modern: How Creative Minds Changed Society, Chicago: University of Chicago Press, 2012.

James-Chakraborty, Kathleen. Bauhaus Culture: From Weimar to the Cold War. Minneapolis: University of Minnesota Press, 2006.

Jodidio, Philip. Architecture in the United States. Taschen America, LLC, 2006.

Lambert, Phyllis and Sylvia Lavin. Modern Views: Inspired by the Mies van der Rohe Farnsworth House and the Philip Johnson Glass House. New York: Assouline, 2010.

Khan, Hasan-Uddin. International Style: Modernist Architecture from 1925 to 1965. Taschen America, LLC, 1998.

Masello, David. Architecture Without Rules: Houses of Marcel Breuer and Herbert Beckhard, New York:W.W.Norton, 1996.

Marcel Breuer Digital Archive, Syracuse University Library, Syracruse, http://breuer.syr.ed.

Marcel Breuer Papers, Smithsonian Archive of American Art, Washington D.C, http://www.aaa.si.edu/collections/marcel-breuer-papers-5596.

Marcel Breuer, World Famous Architect, to Design New Library Building Here, Clarksburg, WV: The Clarksburg Exponent, 1973, January 11.

Meyer, Ulf. Bauhause Culture, From Weimar to the Cold War, Minneapolis: Universiry of Minnesota Press, 1993.

Papachristou,Tician. Marcel Breuer, New Buildings and Projects. New York: Praeger Publishing, Inc., 1970. 
Roy F. Weston. Clarksburg, West Virginia Comprehensive Plan, West Chester, PA: R.F. Weston, 1973.

Schulze, Franz. Mies van der Rohe, A Critical Biography, Chicago: The University of Chicago Press: 1985.

Sharp, Dennis. Bauhaus, Dessau:Walter Gropius. London: Phaidon Press Limited, 1993.

Silver, Adele Z. "The New Education Wing Cleveland Museum of Art." Museum International 25, no. 4 (1973): 229-241, doi: 10.1111/j.1468-0033.1973.tb02225.x.

Stoller, Ezra. Whitney Museum of American Art, New York: Princeton Architectural Press, 2000.

The Cleveland Museum of Art, “Art Museum to Open New Education Wing." Cleveland Museum of Art press release, January 31, 1971. Archives of American Art website. http://www.aaa.si.edu/collections/container/viewer/Press-kit-179903.

"The 20(th) Century Form Givers." Time 68, no. 1 (July 2, 1956): 55. Academic Search Complete, EBSCOhost (accessed February 1, 2014).

U.S. Bureau of the Census. Census of the Population, 1970, Vol. 1, Characteristics of the Population, Part 50, West Virginia. Washington, D.C.: Government Printing Office, 1973. http://www2.census.gov/prod2/decennial/documents/00496492v1p50.zip (accessed April 12, 2013.)

What's wrong with this building? Videocassette, Cinema Guild, New York, 1989.

Wells, Matthew. Skyscrapers Structure and Design, New Haven: Yale University Press, 2005.

Werner, Blaser. Mies van der Rohe: The Art of Structure, New York: Praeger, 1965.

Weston, Richard. Modernism. London: Phaidon Press Limited, 1996.

Wilk, Christopher. Marcel Breuer, Furniture and Interiors. Museum of Modern Art, New York, 1981.

Wingler, Hans. The Bauhaus, Weimar, Dessau, Berlin, Chicago. Cambridge: The MIT Press, 1978. 